\title{
Canadian practice guidelines for the treatment of children and adolescents with eating disorders
}

\author{
Jennifer Couturier ${ }^{1 *}$ (D), Leanna Isserlin², Mark Norris², Wendy Spettigue ${ }^{2}$, Melissa Brouwers², Melissa Kimber ${ }^{1}$, \\ Gail McVey ${ }^{3}$, Cheryl Webb ${ }^{1}$, Sheri Findlay ${ }^{1}$, Neera Bhatnagar ${ }^{1}$, Natasha Snelgrove ${ }^{1}$, Amanda Ritsma', \\ Wendy Preskow ${ }^{4}$, Catherine Miller ${ }^{5}$, Jennifer Coelho ${ }^{6}$, Ahmed Boachie ${ }^{3}$, Cathleen Steinegger ${ }^{3}$, Rachel Loewen ${ }^{7}$, \\ Techiya Loewen ${ }^{8}$, Elizabeth Waite ${ }^{8}$, Catherine Ford ${ }^{9}$, Kerry Bourret ${ }^{10}$, Joanne Gusella ${ }^{11}$, Josie Geller ${ }^{6}$, \\ Adele LaFrance ${ }^{12}$, Anick LeClerc ${ }^{13}$, Jennifer Scarborough ${ }^{5}$, Seena Grewal ${ }^{3}$, Monique Jericho ${ }^{14}$, \\ Gina Dimitropoulos ${ }^{14}$ and David Pilon ${ }^{11}$
}

\begin{abstract}
Objectives: Eating disorders are common and serious conditions affecting up to $4 \%$ of the population. The mortality rate is high. Despite the seriousness and prevalence of eating disorders in children and adolescents, no Canadian practice guidelines exist to facilitate treatment decisions. This leaves clinicians without any guidance as to which treatment they should use. Our objective was to produce such a guideline.

Methods: Using systematic review, the Grading of Recommendations Assessment, Development, and Evaluation (GRADE) system, and the assembly of a panel of diverse stakeholders from across the country, we developed high quality treatment guidelines that are focused on interventions for children and adolescents with eating disorders.

Results: Strong recommendations were supported specifically in favour of Family-Based Treatment, and more generally in terms of least intensive treatment environment. Weak recommendations in favour of Multi-Family Therapy, Cognitive Behavioural Therapy, Adolescent Focused Psychotherapy, adjunctive Yoga and atypical antipsychotics were confirmed.
\end{abstract}

Conclusions: Several gaps for future work were identified including enhanced research efforts on new primary and adjunctive treatments in order to address severe eating disorders and complex co-morbidities.

Keywords: Guidelines, Adolescent, Anorexia nervosa, Bulimia nervosa, Avoidant/restrictive food intake disorder

\section{Plain English summary}

The objective of this project was to develop Canadian Practice Guidelines for the treatment of children and adolescents with eating disorders. We reviewed the literature for relevant studies, rated the quality of the scientific information within these studies, and then reviewed this information with a panel of clinicians, researchers, parents and those with lived experience from across the country. The panel came up with a list of recommendations regarding specific treatments. These recommendations included strong recommendations for the provision of Family-Based Treatment, as well as care provided in a least intensive environment. Weak recommendations were determined for Multi-Family Therapy, Cognitive Behavioural Therapy, Adolescent Focused Psychotherapy, adjunctive Yoga, and atypical antipsychotics. The panel also identified several areas for future research including the development of new treatments for severe and complex eating disorders.

\section{Introduction}

Eating disorders are common and serious conditions affecting up to $4 \%$ of the population [1]. The mortality

* Correspondence: coutur@mcmaster.ca

${ }^{1}$ McMaster University, Hamilton, Canada

Full list of author information is available at the end of the article

(c) The Author(s). 2020 Open Access This article is distributed under the terms of the Creative Commons Attribution 4.0 International License (http://creativecommons.org/licenses/by/4.0/), which permits unrestricted use, distribution, and reproduction in any medium, provided you give appropriate credit to the original author(s) and the source, provide a link to the Creative Commons license, and indicate if changes were made. The Creative Commons Public Domain Dedication waiver (http://creativecommons.org/publicdomain/zero/1.0/) applies to the data made available in this article, unless otherwise stated. 
rate, particularly for Anorexia Nervosa (AN) is high [2, 3], and has been shown to increase by $5.6 \%$ for each decade that an individual remains ill $[4,5]$. It is well-documented that interventions targeted at earlier stages of illness are critically important, given the evidence showing that earlier treatment leads to better outcomes [6, 7]. Despite the seriousness and prevalence of eating disorders in children and adolescents, no Canadian practice guidelines exist to facilitate treatment decisions. This leaves clinicians without any guidance as to which treatment they should use. We systematically reviewed and synthesized the knowledge available on treatments for children and adolescents with eating disorders to develop our guidelines.

\section{Review of existing guidelines}

In the United States, practice parameters have been published by the American Academy of Child and Adolescent Psychiatry for youth with eating disorders [8]. These parameters reflect good clinical practice rather than making statements as to the strength of the evidence to support the recommendations. Clinical practice guidelines have also been developed by the National Institute of Health and Care Excellence [9], however, grading of the evidence is also not presented in these guidelines. The Academy for Eating Disorders has also published guidelines on their website that focus on medical management, but do not focus on psychotherapeutic/psychopharmacological interventions, nor the strength of the evidence (http://aedweb.org/web/downloads/Guide-English.pdf). In summary, guidelines that are currently available tend to focus on medical stabilization, and neglect psychotherapeutic/psychopharmacological approaches to treating eating disorders. Furthermore, they do not rate the strength of evidence. No Canadian guidelines focused on eating disorders in the pediatric age group exist.

\section{Objectives}

Our aim was to synthesize the best available evidence on treatments for children and adolescents with eating disorders resulting in the production of a practice guideline. The research questions to drive this knowledge synthesis were discussed by our research team and guideline development panel, and are listed below.

\section{Research questions}

What are the best treatments available for children and adolescents diagnosed with eating disorders?

a) How effective is Family-Based Treatment for Anorexia Nervosa?

b) How effective is Family-Based Treatment for Bulimia Nervosa?

c) How effective is Cognitive Behavioural Therapy for Bulimia Nervosa? d) How effective is Dialectical Behaviour Therapy for Bulimia Nervosa?

e) How effective are Atypical Antipsychotics for Anorexia Nervosa?

f) How effective are Selective Serotonin Reuptake Inhibitors for Bulimia Nervosa?

g) How effective is day treatment for any type of eating disorder?

h) How effective is inpatient treatment for any type of eating disorder?

\section{Methods}

\section{Overview}

We used systematic review of the literature to arrive at a knowledge synthesis of the best treatments for children and adolescents with eating disorders. This was followed by a grading of the evidence using the Grading of Recommendations Assessment, Development, and Evaluation (GRADE) system [10-12]. These evidence profiles were then presented to a panel of stakeholders from across Canada, followed by a voting system and arrival at consensus on the recommendations. The Appraisal of Guidelines, Research, and Evaluation (AGREE II) tool was used to inform guideline development and reporting [13].

\section{Synthesis methods \\ Eligibility criteria}

Following the principles outlined in the Cochrane Reviewer's Handbook [14] and the Users' Guides to Medical Literature [15], our inclusion criteria were:

A) Criteria pertaining to study validity: i) metaanalyses, randomized controlled trials, open trials, case series, and case reports,

B) Criteria pertaining to the subjects: i) involving children and adolescents (under age 18 years), ii) with eating disorders (Anorexia Nervosa, Bulimia Nervosa, Eating Disorder Not Otherwise Specified, Other Specified Feeding and Eating Disorder, Avoidant/Restrictive Food Intake Disorder, Binge Eating Disorder),

C) Criteria pertaining to the intervention: i) focusing on treatments including, but not limited to, FamilyBased Treatment, Cognitive Behavioural Therapy, Dialectical Behavioural Therapy, Atypical Antipsychotics, Selective Serotonin Reuptake Inhibitors, Day Treatment, and Inpatient Treatment,

D) Criteria pertaining to the Outcome: i) weight (along with variants of weight such as BMI, treatment goal weight (TGW), etc.), ii) binge/purge frequency, iii) psychological symptoms such as drive for thinness, weight/shape preoccupation, and

E) Articles written in any language. 
Exclusion criteria included: i) studies involving primarily adults (18 years or above), ii) studies focusing on medical management, iii) studies focusing on medical outcomes such as bone density, heart rate, iv) studies examining medical treatments such as hormone therapy, calcium, nutrition therapy, v) studies examining other medications. These exclusion criteria were developed for several reasons. We wanted to focus on treatments that were psychopharmacological and psychological in nature, along with outcomes that were central to the core features of eating disorders. We were trying to keep things as simple as possible when thinking of outcomes, especially with the goal of trying to combine studies in a narrative summary or even in a meta-analysis if possible. We focused on a couple of core outcomes with these goals in mind, so therefore excluded papers focusing on other physical outcomes (although these outcomes may indeed be related to weight status).

\section{Identifying potentially eligible studies Databases}

A literature search was completed using the following databases: Medline, PsycINFO, EMBASE, Cochrane Database of Systematic Reviews, Cochrane Central Register of Controlled Trials (CENTRAL) and CINAHL. The references of relevant articles obtained were also reviewed. This was an iterative process, such that search terms were added based on developing ideas and articles obtained.

\section{Literature search strategy}

Initially, an environmental scan of existing guidelines for children and adolescents with eating disorders was completed by the core research team using search terms "guidelines" and "eating disorders" in children and adolescents. Our library scientist then designed and executed comprehensive searches in the databases listed above to obtain evidence to align with each of the guideline questions. The searches included a combination of appropriate keyword and subject heading for each concept. The sample search strategy included, but was not limited to, various combinations of the following terms as appropriate for the questions being addressed: Anorexia nervosa OR bulimia nervosa OR eating disorder not otherwise specified OR other specified feeding and eating disorder OR avoidant/restrictive food intake disorder; AND familybased treatment OR cognitive behavioural therapy OR dialectical behavioural therapy OR atypical antipsychotics OR selective serotonin reuptake inhibitors OR day treatment OR day hospital OR inpatient treatment. The search string was developed further and was modified for each database as appropriate. The search strategy was completed in August 2016. The screening and reviewing process then ensued. Some treatments emerged as important through our search strategy that were not initially identified by our research team and guideline panel as interventions to evaluate. We later included these treatments through panel discussions.

\section{Forward citation chaining}

In November 2018 we used a forward citation chaining process to search each included article to see if it had been cited by any additional articles since August 2016 up until November 2018. We then screened the newly found articles to decide whether to include them. The forward chaining process involved the use of Google Scholar to locate all articles citing our included articles from the primary search.

\section{Other strategies}

Grey literature was also reviewed, including conference proceedings from the International Conference on Eating Disorders dating back the last 10 years (2008-2018). Databases of ongoing research were searched including The Cochrane Central Register of Controlled Trials (CENTRAL). We also hand searched the International Journal of Eating Disorders from the last 10 years for relevant articles (2008-2018).

\section{Applying eligibility criteria and extracting data}

Two team members independently evaluated the results generated by our searches and came to consensus on which studies met eligibility criteria. We used the software Endnote and DistillerSR to organize our studies. DistillerSR was used for article screening and data extraction. Duplicate records identifying the same study were removed. Titles and abstracts were used to exclude obviously irrelevant reports by two reviewers. Potentially relevant articles were reviewed in full text by two reviewers who had to agree on inclusion, with a third resolving disputes. Authors of publications were contacted if any ambiguity existed about inclusion or exclusion. Data abstraction included the number of subjects, sex and/or gender of subjects, age range, type of treatment, type of control group if any, methodology (blinding, allocation concealment, intent-to-treat analysis), types of outcomes, and results. Sex was defined as biological sex, categorized into male or female. Gender was defined as the individual's self-identified gender role/identity, categorized as girl, boy, or transgendered.

\section{Appraising studies}

The Grading of Recommendations Assessment, Development, and Evaluation (GRADE) system explicitly describes how to rate the quality of each study, as well as how to synthesize the evidence and grade the strength of a recommendation [10-12]. Using this system, we developed an evidence profile of each included study that detailed all of the relevant data about the quality and 
strength of evidence for that particular study. Each evidence profile was created using GRADEpro software. We then used the GRADE system to synthesize and classify the overall quality of evidence for each intervention based on the quality of all of the studies using that intervention combined, taking into account risk of bias, inconsistency, indirectness, imprecision, publication bias, dose-response, and effect size. Although we looked at each outcome independently, when the rating of the evidence was the same, we collapsed the outcomes in the GRADEpro tables for the sake of efficiency.

\section{Guideline-related frameworks}

The Appraisal of Guidelines, Research, and Evaluation (AGREE II) tool is an international standard of practice guideline evaluation that was used to inform our guideline development and reporting, and was developed by a coauthor (MB) [13]. The Guideline Implementability for Decision Excellence Model (GUIDE-M) is a recent model that identifies factors to create recommendations that are optimally implementable [16]. We used these models to guide our methodological processes in the development of our practice guideline.

\section{The guideline team}

The Guideline Team was comprised of a core research team and a larger guideline development panel (GDP). The core team presented the research questions to the GDP, reviewed evidence summaries, formulated practice recommendations, drafted the guideline, and limited biases that could impeach upon the guideline development process [17-19]. The chair of the GDP (MB) is an expert in guideline development having produced the AGREE framework [13]. She is a non-expert in the field of eating disorders, and as such, was an impartial chair. She led the consensus discussions of the GDP and she oversaw conflict-of-interest disclosures and management. A multidisciplinary GDP of 24 diverse stakeholders from across Canada was established including members from academic centres who are experts in the field of eating disorders, multi-disciplinary front-line clinicians/knowledge users from community settings, parent and patient representatives, hospital administrators, and policy-makers (all authors on this guideline).

\section{Procedures}

An initial teleconference was held on May 18, 2016 with the core research team and the GDP to confirm the research questions prior to starting the systematic reviews. The initial teleconference oriented GDP members to the guideline development process, the roles and responsibilities of the GDP, as well as reviewed all conflicts of interest. The research questions were refined, the clinical population and outcomes were discussed, and the target audience reviewed.
Once the reviews were completed and the evidence profiles were generated, an in-person meeting was held at a central location on December 20, 2018. The core research team presented their evidence profiles for discussion with the GDP. The in-person meeting focused on a facilitated discussion of the evidence profiles and draft recommendations generated by the core team. For each question, the panel reviewed the evidence, and discussed: i) whether the interpretation of the evidence put forward by the core team aligned with that of the GDP, ii) strengths and limitations of the evidence base, iii) considerations of the generalizability of the studies, precision of the estimates, and whether the evidence aligned with values and preferences of Canadian patients and clinicians. Alternative interpretations and suggestions for further research were discussed. Minority or dissenting opinions were noted. Issues regarding implementability of the recommendations were considered, and suggestions for dissemination of the guideline were elicited.

Following the in-person meeting, GDP members were provided with the draft guidelines for review and approval. Group consensus on recommendations and strength of recommendations was obtained using a modified Delphi method [20], with voting by all GDP members using an anonymous web-based survey platform, Lime Survey (www.limesurvey.com). For a recommendation to be approved, at least $70 \%$ of the GDP were required to identify their agreement with the recommendation [12]. Consensus was achieved in the first round of voting. The GDP agreed to review and update the guideline every 5 years.

\section{External review}

The purpose of the external review was to add validity to our guideline, but also initiate the dissemination process and elicit suggestions for dissemination and implementation. We invited review from four clinical and research experts in the area of pediatric eating disorders. Upon receiving external review, a summary of the review comments and suggestions was circulated to the GDP, along with a final version of the guideline for approval. The panel again discussed and voted on the changes suggested by the reviewers which included the addition of one further recommendation.

\section{Results}

\section{Family therapy}

Three thousand, five hundred and twenty-two abstracts were identified for review within the family therapy section of our guideline (see PRISMA flow diagram, Fig. 1). Nineteen additional abstracts were identified through citation chaining (up to November 23, 2018) and review of reference lists. Two additional papers were identified through external review. After duplicates were removed, abstracts screened, and full text articles reviewed, 74 


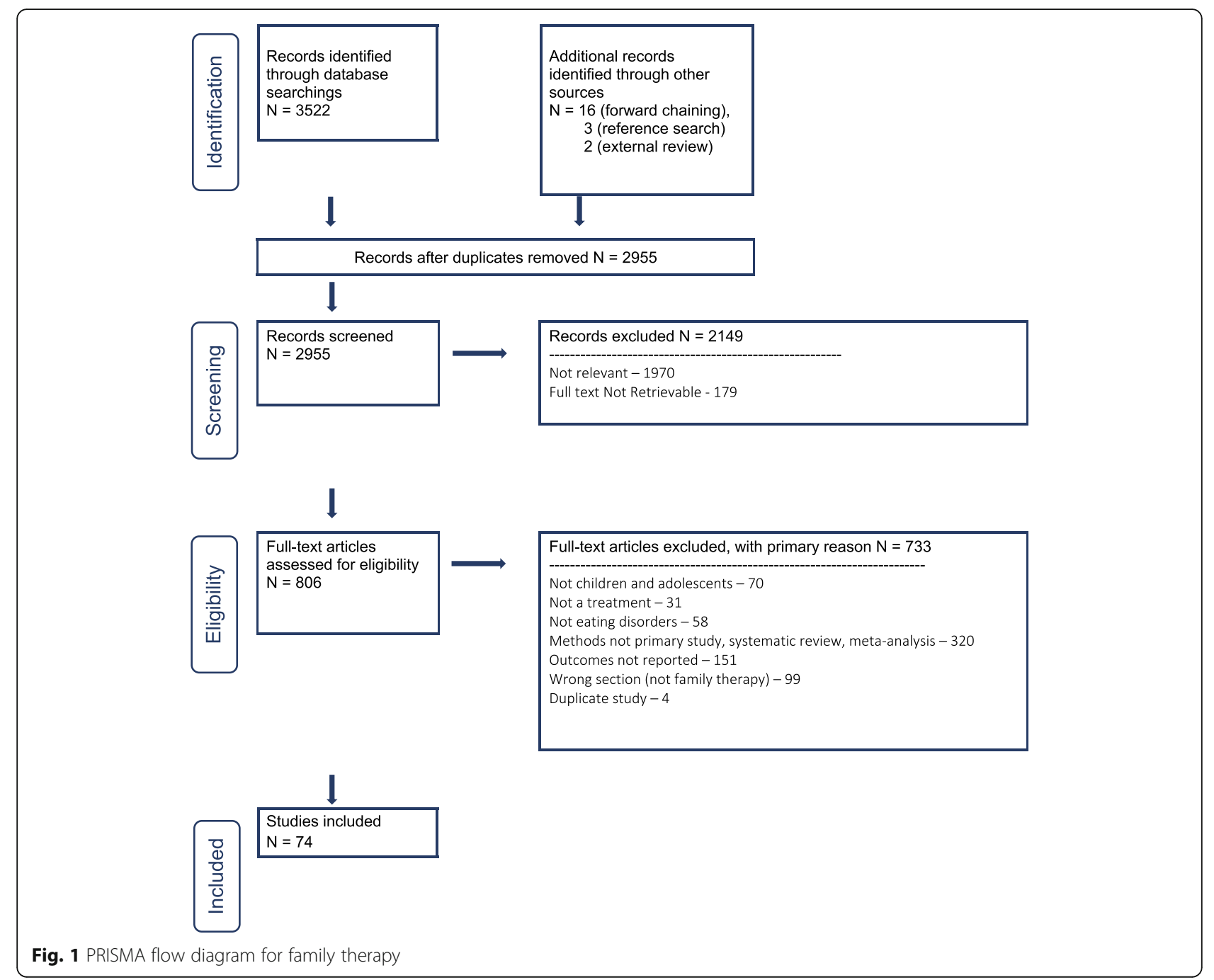

studies were included within the family therapy section of our guideline.

\section{Family-based treatment}

Anorexia nervosa Of all treatments examined, FamilyBased Treatment (FBT), in which parents are placed in charge of the refeeding process, had the most evidence to support its use in children and adolescents with Anorexia Nervosa (AN). One meta-analysis [21] and three high quality RCTs have demonstrated that greater weight gain and higher remission rates are achieved in FBT compared to individual treatment, especially when looking at 1 year follow up [6, 22, 23] (Table 1). One RCT compared a similar behavioural family systems therapy to Cognitive Behavioural Therapy (CBT) and found no significant differences [24], however the sample size was small (Table 1).
In terms of nonrandomized studies, a case-control study of 34 patients treated with FBT compared to 14 treated with "nonspecific therapy" indicated that those in FBT made greater gains in body weight and were less likely to be hospitalized [25]. Seven case series (223 patients) also showed improvement in weight following treatment with FBT [26-32]. Eleven additional case reports (number of total patients $=29)$ are described showing benefit of FBT in terms of weight gain [33, 35-38, 40-44]. Some of these focus on twins [35, 42, 44], comorbid conversion disorder [43], FBT in a group home setting [38], FBT started on a medical unit [39], and FBT combined with medication [42].

Parent-Focused Family Therapy; a type of FBT in which most of the session is spent with the parents alone, may be just as effective as traditional FBT where the family is seen together [45-47] (Table 2).

Bulimia nervosa Three high quality RCTs for Bulimia Nervosa (BN) have been completed and compared FBT 


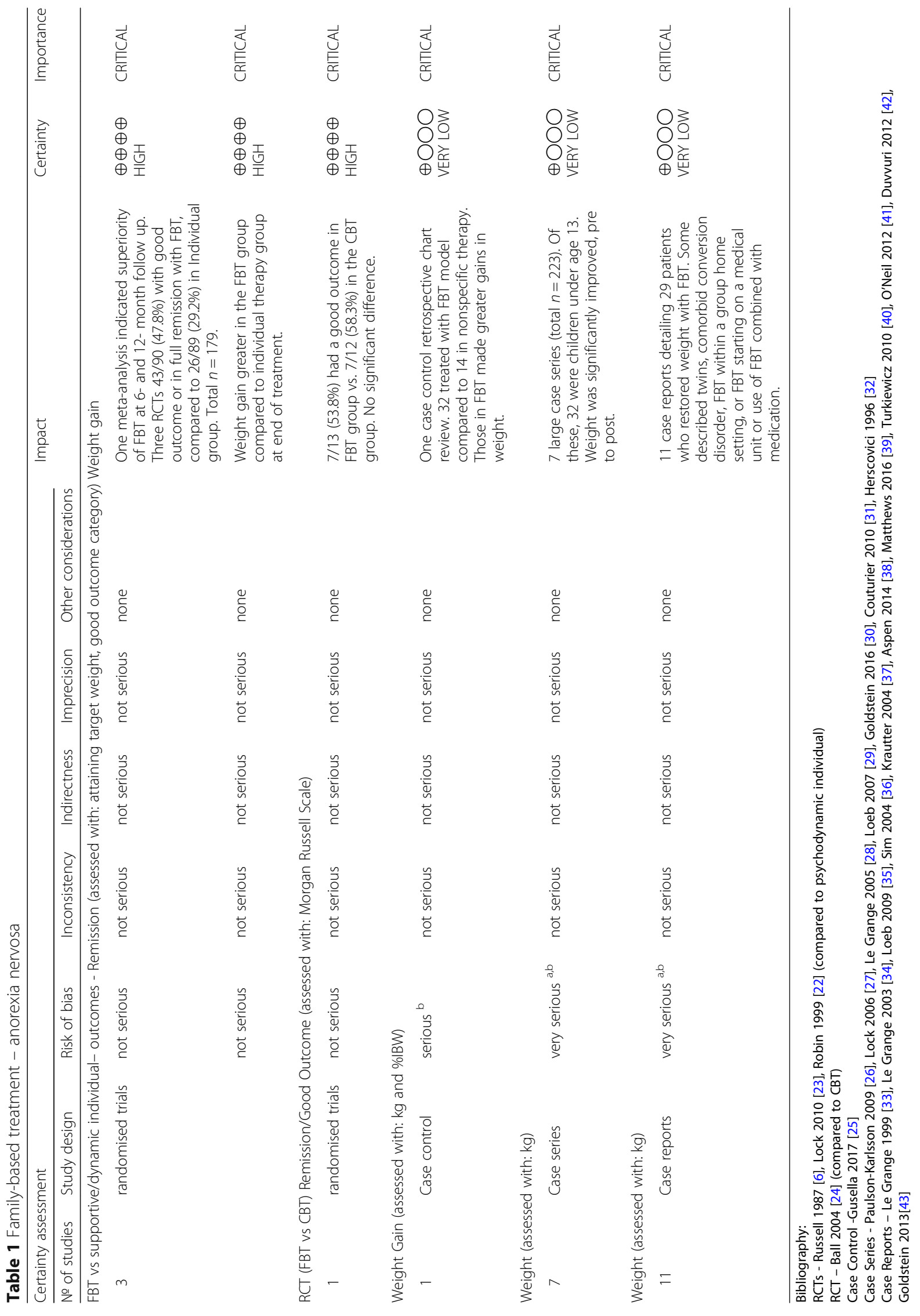


Table 2 Parent focused FBT compared to standard FBT for children and adolescents with anorexia nervosa

\begin{tabular}{|c|c|c|c|c|c|c|c|c|c|}
\hline \multicolumn{7}{|c|}{ Certainty assessment } & \multirow[t]{2}{*}{ Impact } & \multirow[t]{2}{*}{ Certainty } & \multirow[t]{2}{*}{ Importance } \\
\hline $\begin{array}{l}\text { № of } \\
\text { studies }\end{array}$ & Study design & $\begin{array}{l}\text { Risk of } \\
\text { bias }\end{array}$ & Inconsistency & Indirectness & Imprecision & $\begin{array}{l}\text { Other } \\
\text { considerations }\end{array}$ & & & \\
\hline \multicolumn{10}{|c|}{ Remission (assessed with: Weight greater than 95\% and EDE score within 1 SD), Weight (kg), Psychological symptoms (EDI score) } \\
\hline \multirow[t]{3}{*}{3} & $\begin{array}{l}\text { Randomized } \\
\text { Trials }\end{array}$ & $\begin{array}{l}\text { not } \\
\text { serious }\end{array}$ & not serious & not serious & not serious & none & $\begin{array}{l}\text { one RCT ( } n=107) \text { adolescents } \\
\text { aged } 12-18 . \text { Remission higher } \\
\text { in Separated FBT ( } 43 \% \text { vs. 22\%) } \\
\text { compared to Standard FBT at } \\
\text { end of treatment. }\end{array}$ & $\begin{array}{l}\oplus \oplus \oplus \oplus \\
\mathrm{HIGH}\end{array}$ & CRITICAL \\
\hline & & $\begin{array}{l}\text { not } \\
\text { serious }\end{array}$ & not serious & not serious & not serious & none & $\begin{array}{l}\text { one RCT }(n=40) \text {, found no } \\
\text { differences in weight outcome } \\
\text { at end of treatment, except } \\
\text { when subgroups analyzed. } \\
\text { Those with high expressed } \\
\text { emotion did better in separated } \\
\text { family therapy in terms of } \\
\text { weight gain. } \\
\text { One pilot RCT ( } n=18 \text { ) found } \\
\text { no differences in weight outcome } \\
\text { at the end of treatment; both } \\
\text { groups improved. }\end{array}$ & 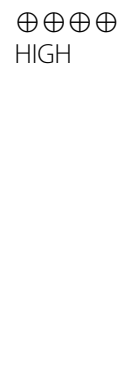 & CRITICAL \\
\hline & & $\begin{array}{l}\text { not } \\
\text { serious }\end{array}$ & not serious & not serious & not serious & none & $\begin{array}{l}\text { Improvement in EDI score was } \\
\text { greater in the standard FBT } \\
\text { group compared to the } \\
\text { separated group. } \\
\text { One pilot RCT ( } n=18 \text { ) found } \\
\text { both groups improved in EAT } \\
\text { scores with no difference } \\
\text { between groups. }\end{array}$ & $\begin{array}{l}\oplus \oplus \oplus \oplus \\
\mathrm{HIGH}\end{array}$ & CRITICAL \\
\hline
\end{tabular}

to varying groups [48-50]. When FBT was compared to CBT, remission rates were significantly higher in the FBT group (39\% versus 20\%) [50]. Remission rates were also significantly better in the FBT group compared to supportive psychotherapy (39\% versus 18\% )[48]. However, when family therapy (with some elements consistent with FBT) was compared to guided self-help CBT, there were no significant differences (10\% versus 14\%) [49]. The adolescents in this study were slightly older and had the option to involve a "close other" rather than a parent, which may have resulted in lower remission rates. A case series and case report also support the use of FBT for BN $[34,51]$ (Table 3).

\section{Family-based treatment with other populations}

Family-Based Treatment has been used for children and adolescents with atypical AN [52]. This case series of 42 adolescents who were not underweight but had lost a significant amount of weight, indicated that there were significant improvements in eating disorder and depressive symptoms, but no improvement in self-esteem (Table 4).

Two case reports describe the application of FBT for children with Avoidant/Restrictive Food Intake Disorder
(ARFID) [53, 54]. These case reports $(n=7$ cases total) indicate that weight improved in all cases (Table 4).

Family-Based Treatment and other family therapies for children and adolescents with eating disorders across the gender spectrum, including those who are gender variant or nonconforming requires more study. However, there is one case report describing the application of FBT with a transgendered youth, along with complexities that arose [55] (Table 4).

\section{Adaptations to family-based treatment for anorexia nervosa}

Adaptations to FBT, such as shorter or longer treatment [56], removal of the family meal [57], guided self-help [58], parent to parent consult [59], adaptive FBT involving extra sessions and another family meal [60], short term intensive formats $[61,62]$ and delivery of FBT by telehealth $[63,64]$, appear promising, but require more study (Table 5).

\section{Adjuncts to family-based treatment for anorexia nervosa}

Adjuncts to FBT, in which additional treatments have been added to FBT, such as cognitive remediation therapy versus art therapy [65], parental skills workshops [66] and Dialectical Behavioural Therapy (DBT) [67] for 
Table 3 Family-based treatment for bulimia nervosa

\begin{tabular}{|c|c|c|c|c|c|c|c|c|c|}
\hline \multicolumn{7}{|c|}{ Certainty assessment } & \multirow[t]{2}{*}{ Impact } & \multirow[t]{2}{*}{ Certainty } & \multirow[t]{2}{*}{ Importance } \\
\hline $\begin{array}{l}\text { № of } \\
\text { studies }\end{array}$ & $\begin{array}{l}\text { Study } \\
\text { design }\end{array}$ & $\begin{array}{l}\text { Risk of } \\
\text { bias }\end{array}$ & Inconsistency & Indirectness & Imprecision & $\begin{array}{l}\text { Other } \\
\text { considerations }\end{array}$ & & & \\
\hline \multicolumn{10}{|c|}{$\begin{array}{l}\text { Remission (assessed with: Abstinence from binge or purge behaviour for } 4 \text { weeks) Psychological Symptoms (assessed with: EDE), Depression } \\
\text { (assessed with: BDI), }\end{array}$} \\
\hline \multirow[t]{3}{*}{3} & \multirow[t]{3}{*}{$\begin{array}{l}\text { randomised } \\
\text { trials }\end{array}$} & $\begin{array}{l}\text { not } \\
\text { serious }\end{array}$ & serious $\mathrm{a}, \mathrm{b}, \mathrm{c}$ & not serious & not serious & none & $\begin{array}{l}\text { one RCT ( } n=130 \text { ) compared FBT } \\
\text { to CBT for adolescents with BN. } \\
\text { FBT group achieved significantly } \\
\text { higher remission rates ( } 39 \% \text { vs. } \\
20 \% \text { ) at end of study. One RCT } \\
\text { (n-85) compared FBT to CBT } \\
\text { guided self care and found no } \\
\text { difference in BP remission } \\
\text { (although Binge alone was } \\
\text { decreased in the CBT group). } \\
\text { One RCT randomized } 80 \text { patients } \\
\text { to FBT or supportive } \\
\text { psychotherapy. } 39 \% \text { in FBT vs. } \\
18 \% \text { in supportive therapy were } \\
\text { in remission at end of treatment; } \\
\text { a significant difference. }\end{array}$ & $\begin{array}{l}\oplus \oplus \oplus \bigcirc \\
\text { MODERATE }\end{array}$ & CRITICAL \\
\hline & & $\begin{array}{l}\text { not } \\
\text { serious }\end{array}$ & serious $a, b, c$ & not serious & not serious & none & $\begin{array}{l}\text { one RCT }(n=130) \text { did not find } \\
\text { any differences in EDE score at } \\
\text { end of treatment for FBT vs. CBT } \\
\text { for adolescents with BN. The } \\
\text { other RCT }(n=80) \text { also showed } \\
\text { all EDE scores were more } \\
\text { improved in the FBT group } \\
\text { compared to supportive group. }\end{array}$ & $\begin{array}{l}\oplus \oplus \oplus \bigcirc \\
\text { MODERATE }\end{array}$ & CRITICAL \\
\hline & & $\begin{array}{l}\text { not } \\
\text { serious }\end{array}$ & serious $a, b, c$ & not serious & not serious & none & $\begin{array}{l}\text { One RCT ( } n=130) \text { showed a } \\
\text { decrease in depression scores } \\
\text { that was greater in the FBT group } \\
\text { compared to the CBT group at } \\
\text { the end of the study. Another } \\
\text { RCT }(n=80) \text { did not show any } \\
\text { differences in depression scores } \\
\text { between FBT and supportive } \\
\text { group. }\end{array}$ & $\begin{array}{l}\oplus \oplus \oplus \bigcirc \\
\text { MODERATE }\end{array}$ & CRITICAL \\
\hline \multicolumn{10}{|c|}{ Binge Purge Frequency (assessed with: Frequency Scores) } \\
\hline 2 & $\begin{array}{l}\text { Case } \\
\text { Reports }\end{array}$ & $\begin{array}{l}\text { very } \\
\text { serious d,e }\end{array}$ & not serious & not serious & not serious & none & $\begin{array}{l}\text { Two case reports of } 9 \text { patients in } \\
\text { total describe decreases in binge } \\
\text { and purge behaviours with FBT } \\
\text { pre compared to post. }\end{array}$ & $\begin{array}{l}\oplus \oplus \oplus \bigcirc \\
\text { VERY LOW }\end{array}$ & CRITICAL \\
\hline
\end{tabular}

ane of three RCTs did not find a difference at end of treatment

b one RCT found a difference in psychological symptoms and the other did not

cone RCT showed a difference in depression scores and the other did not

${ }^{d}$ no randomization

e no control condition

Bibliography:

RCTs - Le Grange 2015 [50], Le Grange 2007 [48], Schmidt 2007 [49]

Case Reports - Dodge 1995 [51], LeGrange 2003 [34]

children and adolescents with AN show promise, but require further study (Table 6).

Two case reports describe the application of adjunctive emotion coaching and attachment based strategies to FBT for one male and one female patient with AN [68, 69] (Table 6).

Cognitive Behavioural Therapy has also been added as an adjunct to $\mathrm{FBT}$ for young patients with $\mathrm{AN}$ or $\mathrm{BN}$. For AN, three case series [70-72] and two case reports $[73,74]$ indicate improved weight and psychological symptoms with added modules on perfectionism or exposure (Table 7). For BN, one case control study exists that compared one patient treated with FBT plus CBT to another patient treated with FBT alone, finding that both patients improved in terms of binge/purge symptoms and Eating Disorder Examination (EDE) scores [75] (Table 8).

\section{Multi-family therapy}

One large high quality RCT $(n=169)$ found that MultiFamily Therapy (MFT) conferred additional benefits compared to single family therapy (FT) in terms of remission rates for adolescents with AN (75\% in MFT versus 60\% in FT), although no differences were found on the EDE [76]. There is one case control study examining MFT versus 
Table 4 Family-based treatment for other populations

\begin{tabular}{|c|c|c|c|c|c|c|c|c|c|}
\hline \multicolumn{7}{|c|}{ Certainty assessment } & \multirow[t]{2}{*}{ Impact } & \multirow[t]{2}{*}{ Certainty } & \multirow[t]{2}{*}{ Importance } \\
\hline $\begin{array}{l}\text { № of } \\
\text { studies }\end{array}$ & $\begin{array}{l}\text { Study } \\
\text { design }\end{array}$ & $\begin{array}{l}\text { Risk of } \\
\text { bias }\end{array}$ & Inconsistency & Indirectness & Imprecision & $\begin{array}{l}\text { Other } \\
\text { considerations }\end{array}$ & & & \\
\hline \multicolumn{10}{|c|}{ Atypical AN - Depressive symptoms - Hughes 2017 (atypical AN) [52] } \\
\hline 1 & $\begin{array}{l}\text { Case } \\
\text { series }\end{array}$ & $\begin{array}{l}\text { very } \\
\text { serious } a, b\end{array}$ & not serious & not serious & not serious & none & $\begin{array}{l}\text { Case series of } 42 \text { adolescents } \\
\text { (age } 12 \text { to } 18 \text { years) with } \\
\text { Atypical AN, that is adolescents } \\
\text { who had lost a significant } \\
\text { amount of weight, but were } \\
\text { not currently underweight. } \\
\text { There were significant } \\
\text { decreases in eating disorder } \\
\text { and depressive symptoms } \\
\text { during FBT but no } \\
\text { improvement in self esteem. }\end{array}$ & $\begin{array}{l}\oplus \bigcirc \bigcirc \bigcirc \\
\text { VERY LOW }\end{array}$ & CRITICAL \\
\hline \multicolumn{10}{|c|}{ Case Reports - Spettigue 2018 [53], Murray 2012 [54] (ARFID) } \\
\hline \multicolumn{10}{|c|}{ ARFID - Food Variety (assessed with: clinical impression), Weight } \\
\hline \multirow[t]{2}{*}{2} & $\begin{array}{l}\text { Case } \\
\text { Reports }\end{array}$ & $\begin{array}{l}\text { very } \\
\text { serious }{ }^{a, b}\end{array}$ & not serious & not serious & not serious & none & $\begin{array}{l}\text { Two case reports describe } 7 \\
\text { cases in total ( } 2 \text { male, } \\
5 \text { female) in which ARFID was } \\
\text { treated using a combination } \\
\text { of FBT techniques, as well as } \\
\text { some behavioural rewards } \\
\text { and cognitive strategies. Food } \\
\text { variety improved by clinical } \\
\text { impression. }\end{array}$ & $\begin{array}{l}\oplus \bigcirc \bigcirc \bigcirc \\
\text { VERY LOW }\end{array}$ & CRITICAL \\
\hline & & $\begin{array}{l}\text { very } \\
\text { serious } a, b\end{array}$ & not serious & not serious & not serious & none & Weight improved in all cases. & $\begin{array}{l}\oplus \bigcirc \bigcirc \bigcirc \\
\text { VERY LOW }\end{array}$ & CRITICAL \\
\hline \multicolumn{10}{|c|}{ Case Report - Strandjord 2015 (transgendered youth) [55] } \\
\hline \multicolumn{10}{|c|}{ Transgendered Youth -BMI } \\
\hline 1 & $\begin{array}{l}\text { Case } \\
\text { Report }\end{array}$ & $\begin{array}{l}\text { very } \\
\text { serious } a, b\end{array}$ & not serious & not serious & not serious & none & $\begin{array}{l}16 \text { yo female sex assigned at } \\
\text { birth treated with FBT to } \\
\text { weight restoration then } \\
\text { disclosed gender dysphoria } \\
\text { with a desire to transition to } \\
\text { male gender. BMl } 14.9 \text { before } \\
\text { treatment, and } 19 \text { with treatment. }\end{array}$ & $\begin{array}{l}\oplus \bigcirc \bigcirc \bigcirc \\
\text { VERY LOW }\end{array}$ & CRITICAL \\
\hline
\end{tabular}

ano control condition

bno randomization

treatment as usual (TAU) in 50 female adolescents with AN [77]. Those in the MFT group had a higher percent body weight (99.6\%) versus the TAU group $(95.4 \%)$ at the end of the study. Two case series have also demonstrated a benefit of MFT for adolescents with AN [78, 79], and one case series with a mixed sample of adolescents with AN or BN showed benefit in psychological symptoms [80]. There is also one small case series examining MFT for adolescents with $\mathrm{BN}$ that found improvements in eating disorder symptoms [81] (Table 9).

\section{Other forms of family therapy}

Systemic Family therapy has been used in one RCT [82] and three case reports [83-85] for AN. The high quality RCT compared Systemic Family Therapy to FBT and found no significant differences in terms of remission rates, however, rate of weight gain was greater in the
FBT group and the use of hospitalization was also significantly lower in the FBT group (Table 10). Structural Family Therapy has been studied within two case series $[86,87]$ and two case reports $[88,89]$. Remission rates in the case series were $75 \%(38 / 51)$ by clinical impression (Table 11). Both of these types of family therapy (Systemic and Structural) might be helpful for children and adolescents with $\mathrm{AN}$, but the evidence generally does not indicate superiority to FBT, especially when costs are taken into consideration.

When looking at other nonspecific, family therapies in which family dynamics were examined, there is one high quality RCT which compared family therapy plus TAU to TAU alone [90] and three case reports [91-93] indicating a benefit of family therapy (Table 12). Family therapy has also been compared to family group psychoeducation with no significant differences in 


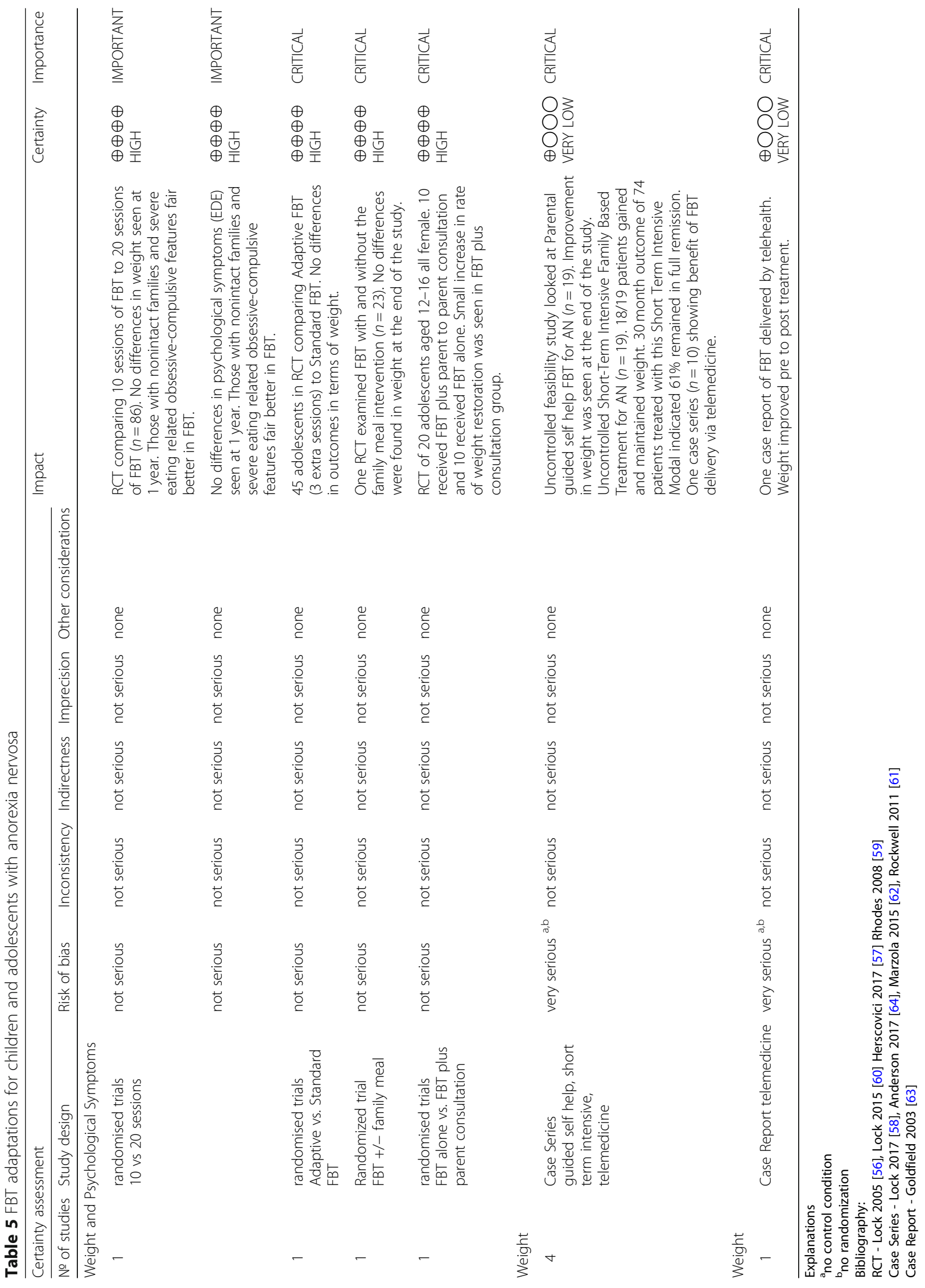




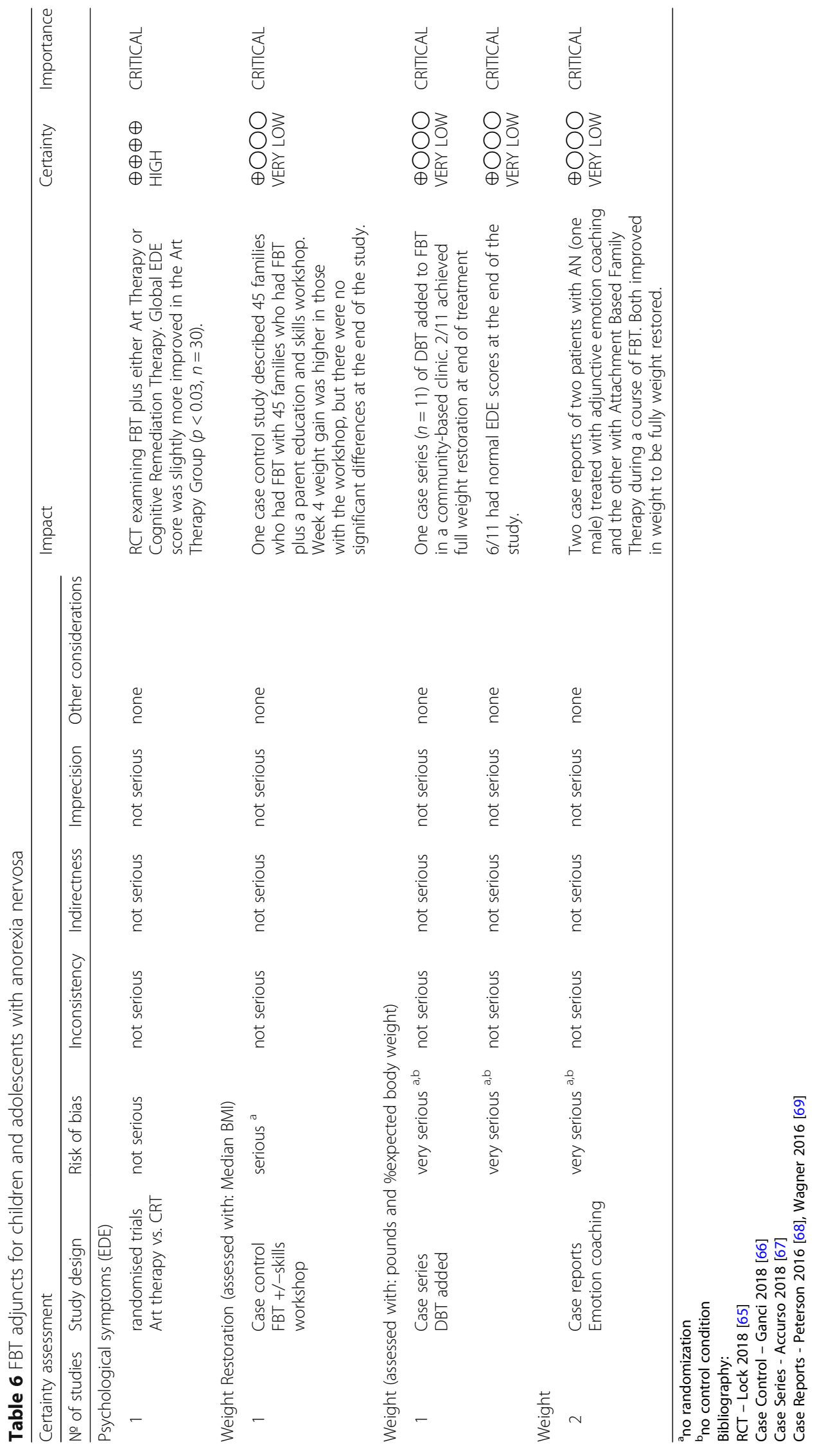


Table 7 FBT plus CBT for children and adolescents with anorexia nervosa

\begin{tabular}{|c|c|c|c|c|c|c|c|c|c|}
\hline \multicolumn{7}{|c|}{ Certainty assessment } & \multirow[t]{2}{*}{ Impact } & \multirow[t]{2}{*}{ Certainty } & \multirow[t]{2}{*}{ Importance } \\
\hline $\begin{array}{l}\text { № of } \\
\text { studies }\end{array}$ & Study design & $\begin{array}{l}\text { Risk of } \\
\text { bias }\end{array}$ & Inconsistency & Indirectness & Imprecision & $\begin{array}{l}\text { Other } \\
\text { considerations }\end{array}$ & & & \\
\hline \multicolumn{10}{|c|}{ Weight (assessed with: percent ideal body weight) Psychological Symptoms of ED (assessed with: EDE and EDI) } \\
\hline \multirow[t]{3}{*}{3} & \multirow[t]{3}{*}{$\begin{array}{l}\text { Case series adding } \\
\text { CBT to FBT }\end{array}$} & $\begin{array}{l}\text { very } \\
\text { serious } a, b\end{array}$ & not serious & not serious & not serious & none & $\begin{array}{l}\text { Total } n=78 \text {. Three case series } \\
\text { looked at a perfectionism } \\
\text { module added to FBT, or an } \\
\text { exposure component to FBT. } \\
\text { Weight increased significantly. } \\
\text { One case series looked at } \\
\text { Acceptance-Based Separated } \\
\text { Family Treatment ( } n=47) \text {, and } \\
\text { also noted weight improved } \\
\text { to ideal weight in about } 50 \% \\
\text { of cases from pre to post } \\
\text { treatment ( } 20 \text { sessions over } \\
24 \text { weeks). }\end{array}$ & $\begin{array}{l}\oplus \bigcirc \bigcirc \bigcirc \\
\text { VERY LOW }\end{array}$ & CRITICAL \\
\hline & & $\begin{array}{l}\text { very } \\
\text { serious } a, b\end{array}$ & not serious & not serious & not serious & none & $\begin{array}{l}\text { In one study } 2 / 3 \text { in full } \\
\text { remission, } 1 / 3 \text { in partial } \\
\text { remission. }\end{array}$ & $\begin{array}{l}\oplus \bigcirc \bigcirc \bigcirc \\
\text { VERY LOW }\end{array}$ & CRITICAL \\
\hline & & $\begin{array}{l}\text { very } \\
\text { serious } a, b\end{array}$ & not serious & not serious & not serious & none & $\begin{array}{l}\text { Decreases in EDE scores and } \\
\text { EDI scores reported. }\end{array}$ & $\begin{array}{l}\oplus \bigcirc \bigcirc \bigcirc \\
\text { VERY LOW }\end{array}$ & CRITICAL \\
\hline \multicolumn{10}{|c|}{ Perfectionism (assessed with: Child and Adolescent Perfectionism Scale) } \\
\hline 2 & Case reports & $\begin{array}{l}\text { very } \\
\text { serious } a, b\end{array}$ & not serious & not serious & not serious & none & $\begin{array}{l}\text { Two case reports ( } n=9 \text { total) } \\
\text { report on decreased } \\
\text { perfectionism scores with the } \\
\text { addition of a CBT perfectionism } \\
\text { module or the addition of } \\
\text { acceptance-based strategies }\end{array}$ & $\begin{array}{l}\oplus \bigcirc \bigcirc \bigcirc \\
\text { VERY LOW }\end{array}$ & IMPORTANT \\
\hline
\end{tabular}

Explanations

ano randomization

${ }^{b}$ no control condition

Bibliography:

Case Series - Hurst 2019 [72], Hildebrandt 2014 [70], Timko 2015 [71]

Case Reports - Hurst 2015 [74], Merwin 2013 [73]

Table 8 FBT plus CBT for children and adolescents with Bulimia Nervosa

\begin{tabular}{|c|c|c|c|c|c|c|c|c|c|}
\hline \multicolumn{7}{|c|}{ Certainty assessment } & \multirow[t]{2}{*}{ Impact } & \multirow[t]{2}{*}{ Certainty } & \multirow[t]{2}{*}{ Importance } \\
\hline $\begin{array}{l}\text { № of } \\
\text { studies }\end{array}$ & $\begin{array}{l}\text { Study } \\
\text { design }\end{array}$ & $\begin{array}{l}\text { Risk of } \\
\text { bias }\end{array}$ & Inconsistency & Indirectness & Imprecision & $\begin{array}{l}\text { Other } \\
\text { considerations }\end{array}$ & & & \\
\hline \multicolumn{10}{|c|}{ Binge Purge Frequency (assessed with: frequency diary), Psychological symptoms (EDE) } \\
\hline \multirow[t]{2}{*}{1} & $\begin{array}{l}\text { Case } \\
\text { control }\end{array}$ & serious $^{a}$ & not serious & not serious & not serious & none & $\begin{array}{l}\text { One } 15 \text { yo female treated with } \\
\text { FBT alone, compared to one } 15 \\
\text { yo female treated with FBT and } \\
\text { CBT ( } 1 \mathrm{~h} \text { sessions were split into } \\
30 \text { min of FBT and } 30 \text { min of CBT). } \\
\text { Both improved significantly - BP } \\
\text { episodes decreased from } 10 \text { to } \\
12 \text { episodes per week to } 0 .\end{array}$ & $\begin{array}{l}\oplus \bigcirc \bigcirc \bigcirc \\
\text { VERY LOW }\end{array}$ & IMPORTANT \\
\hline & & serious $^{\text {a }}$ & not serious & not serious & not serious & none & $\begin{array}{l}\text { EDE scores were collected at end } \\
\text { of this CBT plus FBT compared to } \\
\text { FBT alone study ( } n=2) \text {. EDE scores } \\
\text { were similar in these two patients } \\
\text { and demonstrated normal scores } \\
\text { (in remission). }\end{array}$ & $\begin{array}{l}\oplus \bigcirc \bigcirc \bigcirc \\
\text { VERY LOW }\end{array}$ & IMPORTANT \\
\hline
\end{tabular}




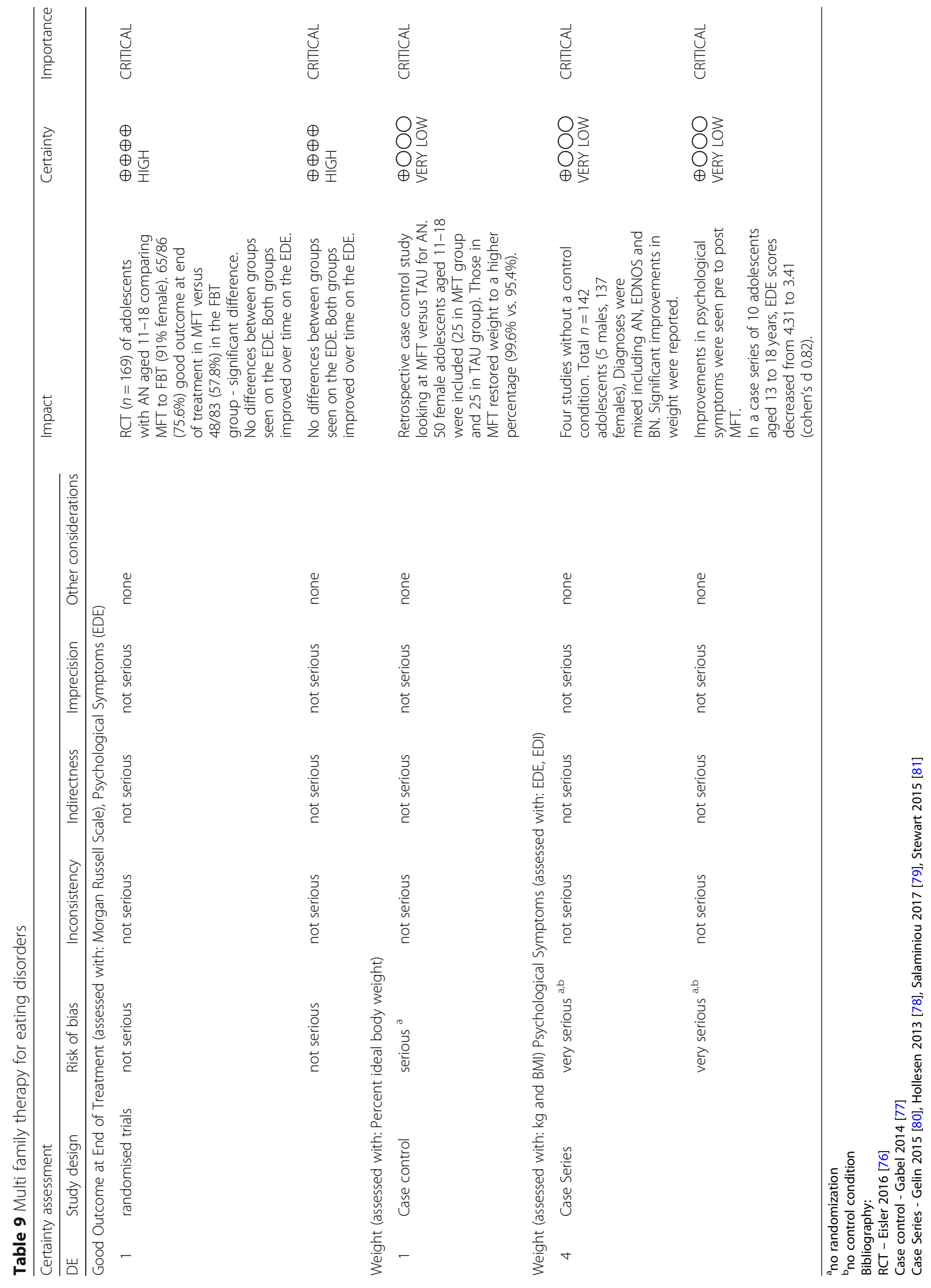


Table 10 Systemic family therapy for anorexia nervosa

\begin{tabular}{|c|c|c|c|c|c|c|c|c|c|}
\hline \multicolumn{7}{|c|}{ Certainty assessment } & \multirow[t]{2}{*}{ Impact } & \multirow[t]{2}{*}{ Certainty } & \multirow[t]{2}{*}{ Importance } \\
\hline $\begin{array}{l}\text { № of } \\
\text { studies }\end{array}$ & Study design & Risk of bias & Inconsistency & Indirectness & Imprecision & $\begin{array}{l}\text { Other } \\
\text { considerations }\end{array}$ & & & \\
\hline \multicolumn{10}{|c|}{ Systemic Family Therapy vs. FBT- Remission (assessed with: greater than 95\% IBW) } \\
\hline \multirow[t]{3}{*}{1} & \multirow[t]{3}{*}{$\begin{array}{l}\text { randomised } \\
\text { trials }\end{array}$} & not serious & not serious & not serious & not serious & none & $\begin{array}{l}\text { One RCT } n=164 \text { ( } 82 \text { in } \\
\text { each group, } 141 \text { were } \\
\text { female). Remission rates } \\
\text { were } 27 / 82 \text { in the FBT } \\
\text { group and } 21 / 82 \text { in the } \\
\text { Systemic Group - not } \\
\text { significantly different. }\end{array}$ & $\begin{array}{l}\oplus \oplus \oplus \oplus \\
\mathrm{HIGH}\end{array}$ & CRITICAL \\
\hline & & not serious & not serious & not serious & not serious & none & $\begin{array}{l}\text { Rate of weight gain } \\
\text { were significantly faster } \\
\text { in the FBT group } \\
\text { compared to the } \\
\text { Systemic Group. }\end{array}$ & $\begin{array}{l}\oplus \oplus \oplus \oplus \\
\mathrm{HIGH}\end{array}$ & CRITICAL \\
\hline & & not serious & not serious & not serious & not serious & none & $\begin{array}{l}\text { No differences were } \\
\text { seen in EDE score at } \\
\text { end of treatment } \\
\text { between FBT and } \\
\text { Systemic Therapy }\end{array}$ & $\begin{array}{l}\oplus \oplus \oplus \oplus \\
\mathrm{HIGH}\end{array}$ & CRITICAL \\
\hline \multicolumn{10}{|c|}{ Weight (assessed with: kg) } \\
\hline 3 & Case Reports & $\begin{array}{l}\text { very } \\
\text { serious }{ }^{a, b}\end{array}$ & not serious & not serious & not serious & none & $\begin{array}{l}\text { Three case reports } \\
\text { describe the use of } \\
\text { systemic family therapy } \\
\text { to good effect in terms } \\
\text { of weight restoration. } \\
\text { One case was a } 14 \text { yo } \\
\text { male in which only the } \\
\text { parents came to some } \\
\text { of the sessions, another } \\
\text { was a } 15 \text { yo female with } \\
\text { comorbid osteosarcoma, } \\
\text { and another is a } 15 \text { yo } \\
\text { male. }\end{array}$ & $\begin{array}{l}\oplus \bigcirc \bigcirc \bigcirc \\
\text { VERY LOW }\end{array}$ & IMPORTANT \\
\hline
\end{tabular}

Explanations

a no control condition

b no randomization

Bibliography:

RCT - Agras 2014 [82]

Case Reports - Carr 1989 [83], De Benedetta 2011 [85], Merl 1989 [84]

outcomes [94]. Both groups were recruited through an inpatient program. Both groups gained weight and were receiving other forms of treatment including medical monitoring and nutritional advice, in addition to the interventions of interest (Table 13).

Emotion focused family therapy (EFFT) was compared in a randomized trial to CBT for 13 adolescents with BN [95] (Table 14). No differences were found in terms of binge/purge symptoms or psychological symptoms at the end of the study, however, the study was likely underpowered to detect differences.

\section{Individual and group outpatient psychotherapies}

Twelve thousand and eleven abstracts were identified in our database searches for the individual and group psychotherapy section of our guideline (see PRISMA flow diagram, Fig. 2). Twenty-five were added with forward chaining up to November 21, 2018, and 15 more through reference list review. Nine thousand, two hundred and eight abstracts were excluded during the abstract screening phase, and a further 1457 were excluded based on full article review, leaving a total of 48 articles included.

\section{Cognitive Behavioural therapy}

Anorexia nervosa A small RCT $(n=22)$ did not show any difference between CBT and Behavioural Family Therapy (similar to FBT) in terms of weight, or psychological symptoms on the EDE for children and adolescents with AN, however, both groups improved [24] (Table 15). One large case series [96] indicated that CBT resulted in weight gain and improvement in eating disorder psychological symptoms for children and adolescent with AN 
Table 11 Structural family therapy for children and adolescents with Anorexia Nervosa

\begin{tabular}{|c|c|c|c|c|c|c|c|c|c|}
\hline \multicolumn{7}{|c|}{ Certainty assessment } & \multirow[t]{2}{*}{ Impact } & \multirow[t]{2}{*}{ Certainty } & \multirow[t]{2}{*}{ Importance } \\
\hline $\begin{array}{l}\text { № of } \\
\text { studies }\end{array}$ & $\begin{array}{l}\text { Study } \\
\text { design }\end{array}$ & $\begin{array}{l}\text { Risk of } \\
\text { bias }\end{array}$ & Inconsistency & Indirectness & Imprecision & $\begin{array}{l}\text { Other } \\
\text { considerations }\end{array}$ & & & \\
\hline \multicolumn{10}{|c|}{ Recovery (assessed with: clinical impression), Weight Gain } \\
\hline \multirow[t]{2}{*}{2} & \multirow[t]{2}{*}{$\begin{array}{l}\text { Case } \\
\text { series }\end{array}$} & $\begin{array}{l}\text { very } \\
\text { serious }{ }^{a, b}\end{array}$ & not serious & not serious & not serious & none & $\begin{array}{l}\text { Two large case series of } 51 \\
\text { female adolescents total } \\
\text { used structural family therapy. } \\
38 / 51(75 \%) \text { were deemed } \\
\text { recovered by clinical } \\
\text { impression. }\end{array}$ & $\begin{array}{l}\oplus \bigcirc \bigcirc \bigcirc \\
\text { VERY LOW }\end{array}$ & CRITICAL \\
\hline & & $\begin{array}{l}\text { very } \\
\text { serious }{ }^{a, b}\end{array}$ & not serious & not serious & not serious & none & $\begin{array}{l}\text { One of these case series } \\
\text { reported between } 5 \text { and } \\
31 \mathrm{~kg} \text { of weight gain with } \\
\text { the treatment }(n=25) \text {. }\end{array}$ & $\begin{array}{l}\oplus \bigcirc \bigcirc \bigcirc \\
\text { VERY LOW }\end{array}$ & CRITICAL \\
\hline \multicolumn{10}{|c|}{ Weight Gain (assessed with: kg) } \\
\hline 2 & $\begin{array}{l}\text { Case } \\
\text { reports }\end{array}$ & $\begin{array}{l}\text { very } \\
\text { serious }{ }^{a, b}\end{array}$ & not serious & not serious & not serious & none & $\begin{array}{l}\text { Two case reports ( } n=2 \text { both } \\
\text { female) report weight } \\
\text { restoration - one of these } \\
\text { cases had co-morbid asthma. }\end{array}$ & $\begin{array}{l}\oplus \bigcirc \bigcirc \bigcirc \\
\text { VERY LOW }\end{array}$ & CRITICAL \\
\hline
\end{tabular}

Explanations

${ }^{a}$ no randomization

b no control condition

Bibliography:

Case Series - Minuchin 1975 [86], Wallin 2002 [87]

Case Reports - Combrinck-Graham 1974 [88], Liebman 1974 [89]

$(n=49)$. Eight additional case reports [97-104] support these results as well. Improvements have also been shown when CBT is delivered in a group setting for $\mathrm{AN}$ in a case control design involving 22 patients [105], and in a case series of 29 adolescents [106] (Table 16).
Bulimia nervosa For $\mathrm{BN}$, three high quality RCTs were found examining CBT (Table 17). One RCT compared CBT to psychodynamic therapy in primarily adolescents, but also some young adults. This trial did not find any difference in terms of remission from BN. There were

Table 12 Family therapy (dynamic) for children and adolescents with Anorexia Nervosa

\begin{tabular}{|c|c|c|c|c|c|c|c|c|c|}
\hline \multicolumn{7}{|c|}{ Certainty assessment } & \multirow[t]{2}{*}{ Impact } & \multirow[t]{2}{*}{ Certainty } & \multirow[t]{2}{*}{ Importance } \\
\hline $\begin{array}{l}\text { № of } \\
\text { studies }\end{array}$ & $\begin{array}{l}\text { Study } \\
\text { design }\end{array}$ & $\begin{array}{l}\text { Risk of } \\
\text { bias }\end{array}$ & Inconsistency & Indirectness & Imprecision & $\begin{array}{l}\text { Other } \\
\text { considerations }\end{array}$ & & & \\
\hline \multicolumn{10}{|c|}{ RCT - Good Outcome (assessed with: Morgan Russell) } \\
\hline 1 & $\begin{array}{l}\text { randomised } \\
\text { trials }\end{array}$ & $\begin{array}{l}\text { not } \\
\text { serious }\end{array}$ & not serious & not serious & not serious & none & $\begin{array}{l}\text { one RCT involving } 60 \\
\text { adolescents randomized } \\
\text { to TAU or TAU plus } \\
\text { Family Therapy looking } \\
\text { at family dynamics. } 12 / 30 \\
\text { had a good outcome in } \\
\text { the FT group compared } \\
\text { to } 5 / 30 \text { in the TAU group } \\
(p<0.05) \text {. }\end{array}$ & $\begin{array}{l}\oplus \oplus \oplus \oplus \\
\mathrm{HIGH}\end{array}$ & CRITICAL \\
\hline \multicolumn{10}{|c|}{ Weight (assessed with: kg) } \\
\hline 3 & $\begin{array}{l}\text { Case } \\
\text { Reports }\end{array}$ & $\begin{array}{l}\text { very } \\
\text { serious a,b }\end{array}$ & not serious & not serious & not serious & none & $\begin{array}{l}\text { three case reports looking } \\
\text { at } 4 \text { female patients (one } \\
\text { set of twins) treated with } \\
\text { family therapy (one } \\
\text { solution focused). Weight } \\
\text { improved in all cases. }\end{array}$ & $\begin{array}{l}\oplus \bigcirc \bigcirc \bigcirc \\
\text { VERY LOW }\end{array}$ & IMPORTANT \\
\hline
\end{tabular}


Table 13 Family therapy compared to family group psychoeducation for adolescents with Anorexia Nervosa

\begin{tabular}{|c|c|c|c|c|c|c|c|c|c|}
\hline \multicolumn{7}{|c|}{ Certainty assessment } & \multirow[t]{2}{*}{ Impact } & \multirow[t]{2}{*}{ Certainty } & \multirow[t]{2}{*}{ Importance } \\
\hline $\begin{array}{l}\text { № of } \\
\text { studies }\end{array}$ & Study design & $\begin{array}{l}\text { Risk of } \\
\text { bias }\end{array}$ & Inconsistency & Indirectness & Imprecision & $\begin{array}{l}\text { Other } \\
\text { considerations }\end{array}$ & & & \\
\hline \multicolumn{10}{|c|}{ Weight Restoration (assessed with: kg) } \\
\hline 1 & $\begin{array}{l}\text { randomised } \\
\text { trials }\end{array}$ & $\begin{array}{l}\text { not } \\
\text { serious }\end{array}$ & not serious & not serious & not serious & none & $\begin{array}{l}\text { No differences in weight } \\
\text { restoration were seen at } \\
\text { the end of the study } \\
\text { between treatments. Both } \\
\text { groups gained weight. } \\
(n=25) \text {. }\end{array}$ & $\begin{array}{l}\oplus \oplus \oplus \oplus \\
\mathrm{HIGH}\end{array}$ & IMPORTANT \\
\hline
\end{tabular}

small differences in terms of a greater reduction in binge-purge frequency in the CBT group [107]. There were also two high quality RCTs identified comparing CBT to family-based approaches for BN $[49,50]$. There are conflicting results between these two studies, with the study by Le Grange and colleagues [50] indicating significantly greater remission rates in the FBT group compared to the CBT group, whereas the study by Schmidt and colleagues [49] showed no significant difference between the groups with only a small proportion remitted in each group. Two large case series indicate significant decreases in binge-purge frequency pre to post treatment $[108,109]$. Several case reports indicating improvement in binge-purge symptoms exist [110-114].

Avoidant/restrictive food intake disorder There were 13 case reports identified in which CBT was used to treat ARFID [115-127]. One of these described the delivery of CBT by telemedicine [127]. One case described the combined treatment of $\mathrm{CBT}$ with fluoxetine for a significant choking phobia [120]. Although these reports are preliminary, improvements in food avoidance were noted in all cases (Table 18).

\section{Adolescent focused psychotherapy}

Anorexia nervosa Adolescent Focused Psychotherapy (AFP: based on psychodynamic principles) [22, 23, 128] and other psychodynamic treatments [129] have some evidence to support their use (Table 19). Remission rates were not significantly different between AFP and FBT in two RCTs involving a total sample of 158 adolescents with AN [22, 23]. Rates of 20\% (12/60) remitted in AFP compared to $34 \%$ (21/60) in FBT were found in a study by Lock and colleagues [23], whereas $41 \%$ in the AFP group met the weight goal of the 50th percentile in a study by Robin and colleagues [22] compared to $53 \%$ in the FBT group. Differences between AFP and FBT became more apparent at 1 year follow-up with FBT demonstrating an advantage [23]. Group analytic psychotherapy also has some evidence to support its use for AN [130] (Table 20).

Table 14 Emotion focused family therapy compared to cognitive behavioural therapy for children and adolescents with Bulimia Nervosa

\begin{tabular}{|c|c|c|c|c|c|c|c|c|c|}
\hline \multicolumn{7}{|c|}{ Certainty assessment } & \multirow[t]{2}{*}{ Impact } & \multirow[t]{2}{*}{ Certainty } & \multirow[t]{2}{*}{ Importance } \\
\hline $\begin{array}{l}\text { № of } \\
\text { studies }\end{array}$ & $\begin{array}{l}\text { Study } \\
\text { design }\end{array}$ & $\begin{array}{l}\text { Risk of } \\
\text { bias }\end{array}$ & Inconsistency & Indirectness & Imprecision & $\begin{array}{l}\text { Other } \\
\text { considerations }\end{array}$ & & & \\
\hline \multicolumn{10}{|c|}{ Binge Purge Frequency (assessed with: frequency), Psychological Symptoms (assessed with: EDI) } \\
\hline \multirow[t]{2}{*}{1} & $\begin{array}{l}\text { randomised } \\
\text { trials }\end{array}$ & $\begin{array}{l}\text { not } \\
\text { serious }\end{array}$ & not serious & not serious & serious $^{\mathrm{a}}$ & none & $\begin{array}{l}n=13 \text { adolescents with } \\
\text { BN randomly assigned to } \\
\text { EFFT or CBT. No differences } \\
\text { in terms of binge purge } \\
\text { frequency at end of study. }\end{array}$ & $\begin{array}{l}\oplus \oplus \oplus \bigcirc \\
\text { MODERATE }\end{array}$ & CRITICAL \\
\hline & & $\begin{array}{l}\text { not } \\
\text { serious }\end{array}$ & not serious & not serious & serious $^{a}$ & none & $\begin{array}{l}\text { No differences in terms } \\
\text { of psychological symptoms } \\
\text { at end of study. Very small } \\
\text { sample size. }\end{array}$ & $\begin{array}{l}\oplus \oplus \oplus \bigcirc \\
\text { MODERATE }\end{array}$ & CRITICAL \\
\hline
\end{tabular}




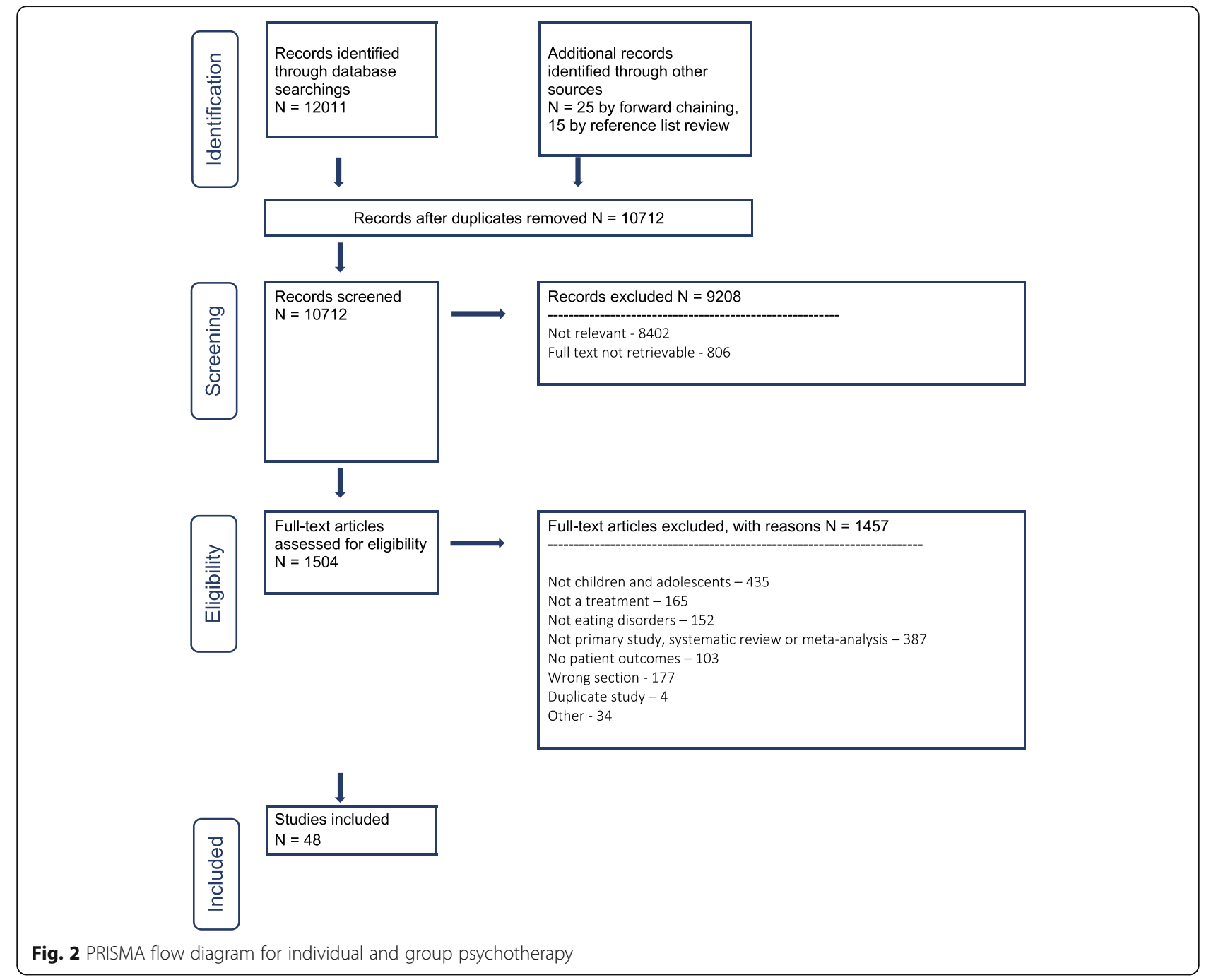

Psychodynamic Therapy (group or individual) for AN may be beneficial, however other treatments have some advantages over psychodynamic therapy in terms of cost and more rapid improvement in symptoms.

\section{Dialectical Behavioural therapy}

Dialectical Behavioural Therapy (DBT) for eating disorders has been applied for youth with AN, BN, Eating Disorder Not Otherwise Specified (EDNOS) and Binge Eating Disorder (BED) with promising results [131-133]. Two case series report decreases in binge-purge symptoms, and improvements in psychological eating disorder symptoms [131, 133], along with reductions in frequency of selfharm in multi-diagnostic youth [131] (Table 21).

\section{Adjunctive treatments}

Cognitive Remediation Therapy (CRT) has been mentioned in the family therapy section of this guideline as an adjunct to FBT [65], however, it has also been studied as an adjunct to other therapies in a case series [134] and a case report [135] for AN (Table 22). It has been used in multiple settings and will be touched upon again within the level of care section of this guideline.

One high quality study suggests some benefits of adjunctive yoga in terms of psychological symptoms of eating disorders, as well as depression and anxiety [136]. In this study, 50 girls and 4 boys were randomly assigned to an 8-week trial of yoga plus standard care versus standard care alone. The majority of the participants had AN (29/54), and others were diagnosed with BN (9/54) and EDNOS (15/54). Eating disorder symptoms measured by the EDE decreased more significantly in the yoga group. Both groups demonstrated maintenance of body mass index (BMI), along with decreases in anxiety and depression scores (Table 23). 


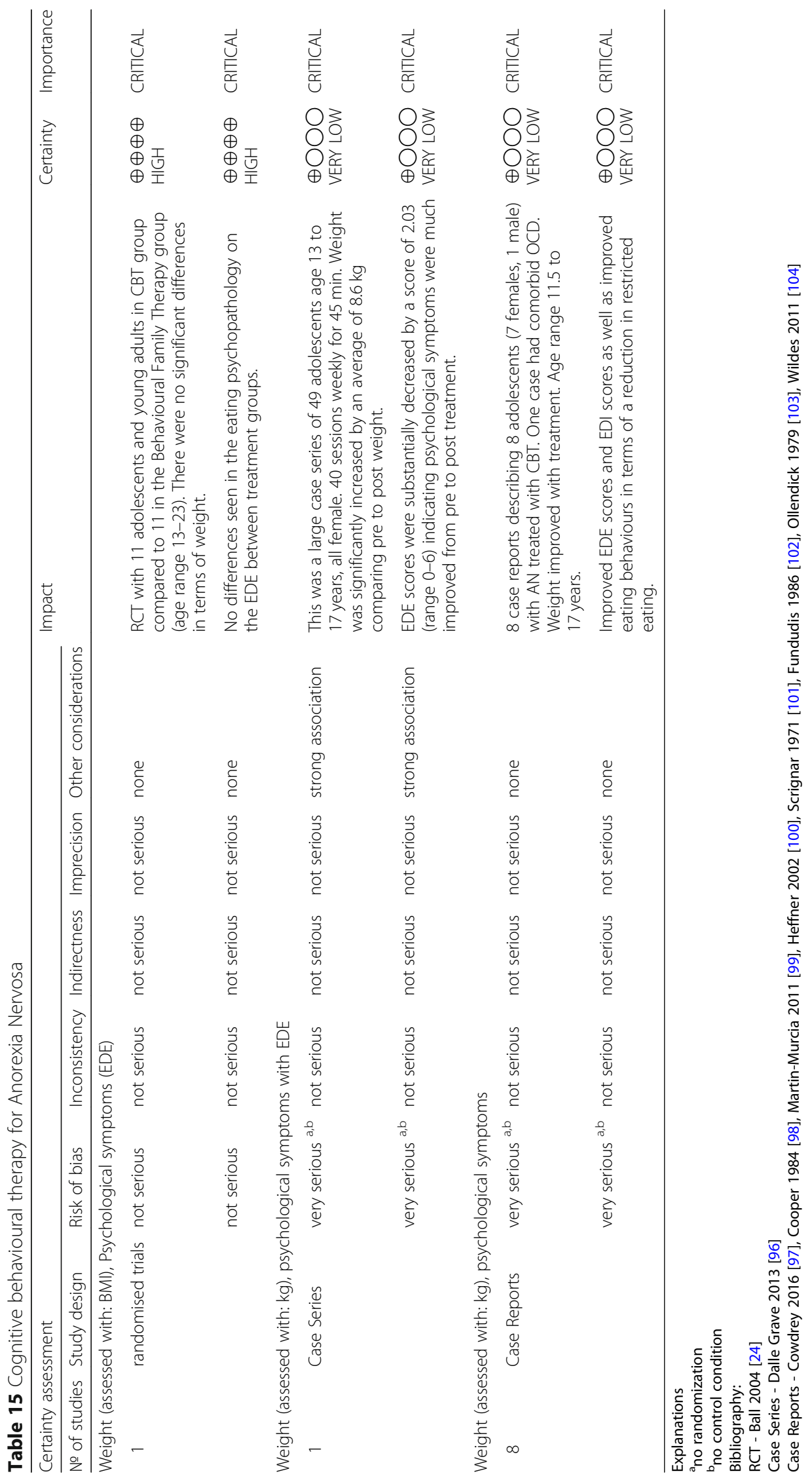


Table 16 Group cognitive behavioural therapy for children and adolescents with Anorexia Nervosa

\begin{tabular}{|c|c|c|c|c|c|c|c|c|c|}
\hline \multicolumn{7}{|c|}{ Certainty assessment } & \multirow{2}{*}{ Impact } & \multirow[t]{2}{*}{ Certainty } & \multirow[t]{2}{*}{ Importance } \\
\hline $\begin{array}{l}\text { № of } \\
\text { studies }\end{array}$ & $\begin{array}{l}\text { Study } \\
\text { design }\end{array}$ & $\begin{array}{l}\text { Risk of } \\
\text { bias }\end{array}$ & Inconsistency & Indirectness & Imprecision & $\begin{array}{l}\text { Other } \\
\text { considerations }\end{array}$ & & & \\
\hline \multicolumn{10}{|c|}{ Weight (assessed with: kg) Psychological Symptoms of ED (assessed with: EDE) } \\
\hline \multirow[t]{2}{*}{1} & \multirow[t]{2}{*}{$\begin{array}{l}\text { Case } \\
\text { Control }\end{array}$} & serious $^{a}$ & not serious & not serious & not serious & none & $\begin{array}{l}\text { This controlled study involved } \\
11 \text { adolescents in the CBT } \\
\text { group condition compared to } \\
11 \text { adolescents in the } \\
\text { treatment as usual condition. } \\
\text { CBT group involved } 24 \text { sessions } \\
\text { ( } 90 \text { min each) over a six-month } \\
\text { period. There were no significant } \\
\text { differences in terms of weight } \\
\text { at the end of treatment. }\end{array}$ & $\begin{array}{l}\oplus \bigcirc \bigcirc \bigcirc \\
\text { VERY LOW }\end{array}$ & CRITICAL \\
\hline & & serious $^{a}$ & not serious & not serious & not serious & none & $\begin{array}{l}\text { Significant difference on the } \\
\text { EDE subscale of Restraint ( } 0.56 \\
\text { vs. } 0.70 \text { - clinical significance } \\
\text { questionable). }\end{array}$ & $\begin{array}{l}\oplus \bigcirc \bigcirc \bigcirc \\
\text { VERY LOW }\end{array}$ & CRITICAL \\
\hline \multicolumn{10}{|c|}{ Weight (assessed with: BMI) Psychological Symptoms of ED (assessed with: EDE) } \\
\hline 1 & $\begin{array}{l}\text { Case } \\
\text { Series }\end{array}$ & $\begin{array}{l}\text { very } \\
\text { serious } a, b\end{array}$ & not serious & not serious & not serious & none & $\begin{array}{l}\text { Case series of } 29 \text { adolescent } \\
\text { females ( } 22 \text { AN-R, } 7 \text { AN-BP). No } \\
\text { control group. } \\
40 \text { sessions of group CBT over } 40 \\
\text { weeks. Weight (BMI) improved pre } \\
\text { to post treatment. EDE restraint } \\
\text { and EDE weight concern improved } \\
\text { Pre to Post treatment. }\end{array}$ & $\begin{array}{l}\oplus \bigcirc \bigcirc \bigcirc \\
\text { VERY LOW }\end{array}$ & CRITICAL \\
\hline
\end{tabular}

Explanations

${ }^{a}$ no randomization

${ }^{b}$ no control condition

Bibliography:

Case Control - Pegado 2018 [105]

Case Series - Ohmann 2013 [106]

\section{Medications}

\section{Atypical antipsychotics}

Two hundred and thirty-six abstracts were identified through database searching for the atypical antipsychotic section of our guideline (see PRISMA flow diagram Fig. 3). Seven additional articles were found through citation chaining and reference list review. After excluding 97 abstracts and then excluding 73 full text articles we arrived at 32 included studies for the atypical antipsychotic section. We then divided up the antipsychotics into their respective categories - Olanzapine, Risperidone, Quetiapine, and Aripiprazole.

\section{Olanzapine}

Anorexia nervosa Olanzapine has been the most commonly studied psychotropic medication for children and adolescents with AN (Table 24). At present, only one double blind placebo-controlled trial in this population has been published. Kafantaris and colleagues [137] examined olanzapine in 20 underweight adolescents being treated in inpatient $(n=9)$, day treatment $(n=6)$ and outpatient $(n=5)$ settings (age range 12.3 to 21.8 years). In a 10-week pilot study, they found no differences in beneficial effect between the olanzapine and placebo groups in the 15 subjects who completed the trial; however, the treated group showed a trend towards increasing fasting glucose and insulin levels by the end of the study. The mean dose of olanzapine was $8.5 \mathrm{mg}$ daily. Of note, only $21 \%$ of eligible patients were recruited into the study and there was a high attrition rate. Although other research teams have also attempted RCTs using olanzapine in this population, trials have been hampered by a myriad of confounding and recruitment issues [155].

Three case control studies have examined the use of olanzapine in children and adolescents with AN [138-140]. The most recent of these studies enrolled 38 patients with $\mathrm{AN} ; 22$ of whom took olanzapine and 10 who declined medication and were retained as a comparison group [138]. The mean dose of medication was $5.28 \mathrm{mg}$ daily over a 12 week trial period. Those in the medication group demonstrated a significantly higher rate of weight gain in the first 4 weeks, although approximately one third of participants discontinued olanzapine early due to side effects [138]. Norris and colleagues [139] completed a retrospective chart 


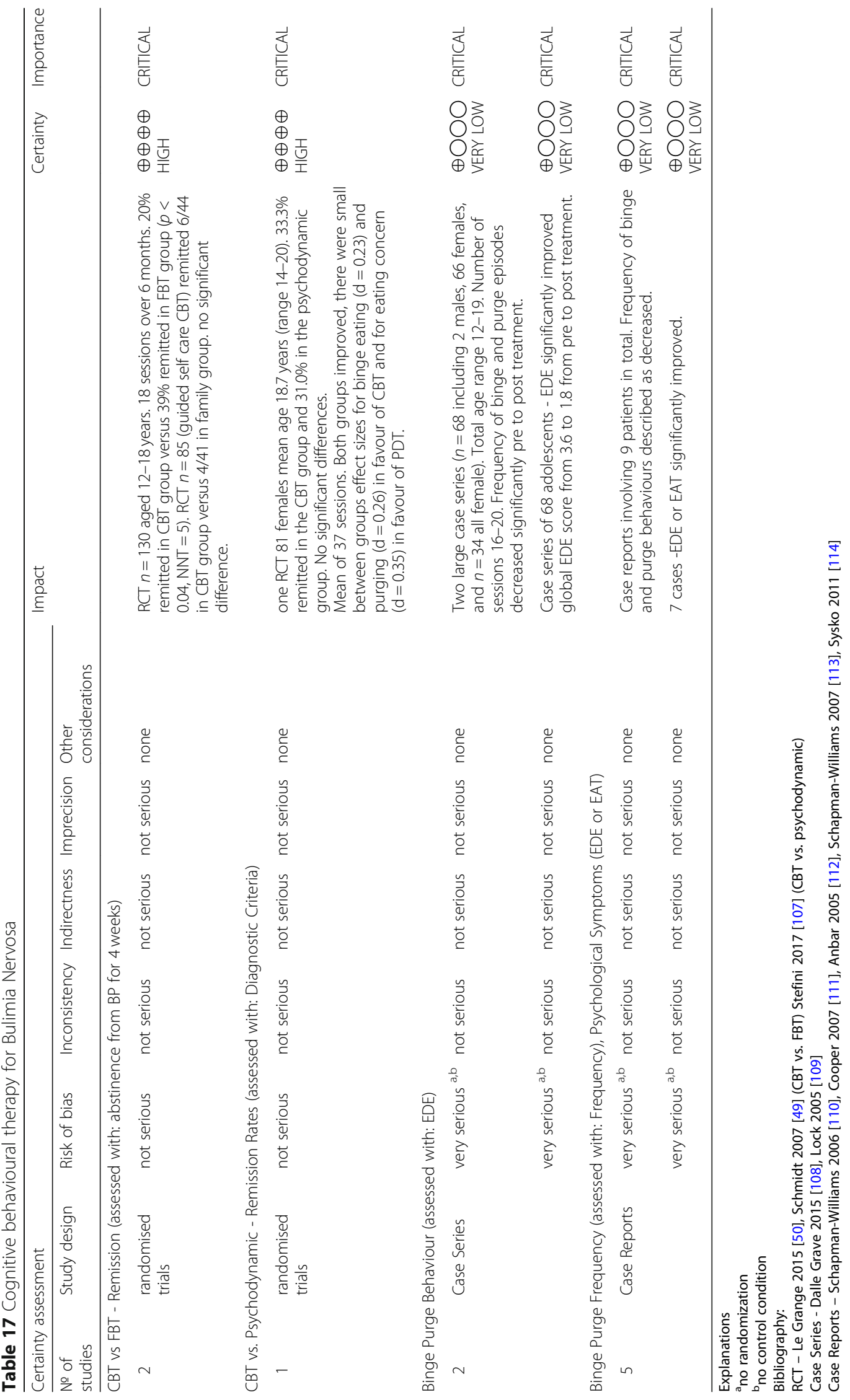


Table 18 Cognitive behavioural therapy for ARFID

\begin{tabular}{|c|c|c|c|c|c|c|c|c|c|}
\hline \multicolumn{7}{|c|}{ Certainty assessment } & \multirow[t]{2}{*}{ Impact } & \multirow[t]{2}{*}{ Certainty } & \multirow[t]{2}{*}{ Importance } \\
\hline $\begin{array}{l}\text { № of } \\
\text { studies }\end{array}$ & $\begin{array}{l}\text { Study } \\
\text { design }\end{array}$ & $\begin{array}{l}\text { Risk of } \\
\text { bias }\end{array}$ & Inconsistency & Indirectness & Imprecision & $\begin{array}{l}\text { Other } \\
\text { considerations }\end{array}$ & & & \\
\hline \multicolumn{10}{|c|}{ Avoidance of Food (assessed with: clinical impression) } \\
\hline 12 & $\begin{array}{l}\text { Case } \\
\text { Reports }\end{array}$ & $\begin{array}{l}\text { very } \\
\text { serious } a, b\end{array}$ & not serious & not serious & not serious & none & $\begin{array}{l}28 \text { cases are described in which } \\
\text { various cognitive behavioural } \\
\text { strategies including systematic } \\
\text { desensitization (17), hypnosis (6) } \\
\text { and EMDR (4) were used. Patients } \\
\text { were aged } 3 \text { to } 16 \text { years ( } 12 \text { male, } \\
16 \text { female). Improvement in food } \\
\text { avoidance behaviour was reported } \\
\text { in all cases. }\end{array}$ & $\begin{array}{l}\oplus \bigcirc \bigcirc \bigcirc \\
\text { VERY LOW }\end{array}$ & IMPORTANT \\
\hline \multicolumn{10}{|c|}{ Telemedicine - Increased food variety (assessed with: bites of nonpreferred food) } \\
\hline 1 & $\begin{array}{l}\text { Case } \\
\text { Report }\end{array}$ & $\begin{array}{l}\text { very } \\
\text { serious } a, b\end{array}$ & not serious & not serious & not serious & none & $\begin{array}{l}\text { Case report with CBT delivered } \\
\text { by teleconsultation to parents } \\
\text { of } 8 \text { year old boy with ARFID. } \\
\text { Increased frequency of bites } \\
\text { of nonpreferred food was noted. }\end{array}$ & $\begin{array}{l}\oplus \bigcirc \bigcirc \bigcirc \\
\text { VERY LOW }\end{array}$ & IMPORTANT \\
\hline
\end{tabular}

Explanations

${ }^{a}$ no randomization

bno control condition

Bibliography:

Case Reports - Murphy 2016 [125], Fischer 2015 [124], Nock 2002 [119], Okada 2007 [122], Ciyiltepe 2006 [121], de Roos 2008 [123], Culbert 1996 [117],

Siegel 1982 [115], Reid 2016 [126], Chatoor 1988 [116], Chorpita 1997 [118], Bloomfield 2018 [127], Bailly 2003 [120]

Table 19 Adolescent focused psychotherapy/psychodynamic for Anorexia Nervosa

\begin{tabular}{|c|c|c|c|c|c|c|c|c|c|}
\hline \multicolumn{7}{|c|}{ Certainty assessment } & \multirow[t]{2}{*}{ Impact } & \multirow[t]{2}{*}{ Certainty } & \multirow[t]{2}{*}{ Importance } \\
\hline $\begin{array}{l}\text { № of } \\
\text { studies }\end{array}$ & $\begin{array}{l}\text { Study } \\
\text { design }\end{array}$ & $\begin{array}{l}\text { Risk of } \\
\text { bias }\end{array}$ & Inconsistency & Indirectness & Imprecision & $\begin{array}{l}\text { Other } \\
\text { considerations }\end{array}$ & & & \\
\hline \multicolumn{10}{|c|}{ Remission (assessed with: normal weight and EDE score) } \\
\hline \multirow[t]{2}{*}{2} & \multirow[t]{2}{*}{$\begin{array}{l}\text { randomised } \\
\text { trials }\end{array}$} & $\begin{array}{l}\text { not } \\
\text { serious }\end{array}$ & not serious & not serious & not serious & none & $\begin{array}{l}\text { RCT of Adolescent Focused } \\
\text { Psychotherapy versus FBT } \\
\text { ( } n=121,11 \text { male, } 110 \text { female, } \\
\text { age } 12-18) .12 / 60 \text { ( } 20 \% \text { ) remitted } \\
\text { at end of treatment in AFT group } \\
\text { versus } 21 / 61 \text { ( } 34.4 \%) \text { in FBT group. } \\
\text { No significant differences in terms } \\
\text { of remission. No differences in } \\
\text { remission in another RCT ( } n=37) \text {. } \\
52.6 \% \text { in FBT reached } 50 \text { th } \\
\text { percentile weight vs. } 41.2 \text { in } \\
\text { individual ( } p<0.05) \text {. }\end{array}$ & $\begin{array}{l}\oplus \oplus \oplus \oplus \\
\mathrm{HIGH}\end{array}$ & CRITICAL \\
\hline & & $\begin{array}{l}\text { not } \\
\text { serious }\end{array}$ & not serious & not serious & not serious & none & $\begin{array}{l}\text { Those in FBT had greater } \\
\text { change on EDE scores at } \\
\text { end of treatment. }\end{array}$ & $\begin{array}{l}\oplus \oplus \oplus \oplus \\
\mathrm{HIGH}\end{array}$ & CRITICAL \\
\hline \multicolumn{10}{|l|}{ Weight } \\
\hline 2 & $\begin{array}{l}\text { Case } \\
\text { Reports }\end{array}$ & $\begin{array}{l}\text { very } \\
\text { serious } a, b\end{array}$ & not serious & not serious & not serious & none & $\begin{array}{l}\text { Two case reports describing } \\
\text { three cases total (age 12-16 } \\
\text { years, all female) in which } \\
\text { psychodynamic therapy over } \\
1-2 \text { years of therapy resulted } \\
\text { in weight restoration. }\end{array}$ & $\begin{array}{l}\oplus \bigcirc \bigcirc \bigcirc \\
\text { VERY LOW }\end{array}$ & CRITICAL \\
\hline
\end{tabular}

\section{Explanations}

a no control condition

${ }^{b}$ no randomization

Bibliography:

RCT - Lock 2010 [23], Robin 1999 [22]

Case Reports - Fitzpatrick 2010 [128], Pharis 1984 [129] 
Table $\mathbf{2 0}$ Group analytic therapy for children and adolescents with AN and BN

\begin{tabular}{|c|c|c|c|c|c|c|c|c|c|}
\hline \multicolumn{7}{|c|}{ Certainty assessment } & \multirow[t]{2}{*}{ Impact } & \multirow[t]{2}{*}{ Certainty } & \multirow[t]{2}{*}{ Importance } \\
\hline $\begin{array}{l}\text { № of } \\
\text { studies }\end{array}$ & $\begin{array}{l}\text { Study } \\
\text { design }\end{array}$ & $\begin{array}{l}\text { Risk of } \\
\text { bias }\end{array}$ & Inconsistency & Indirectness & Imprecision & $\begin{array}{l}\text { Other } \\
\text { considerations }\end{array}$ & & & \\
\hline \multicolumn{10}{|c|}{ Psychological Symptoms (assessed with: EDI, SEED-short evaluation eating disorders) } \\
\hline 1 & $\begin{array}{l}\text { Case } \\
\text { Reports }\end{array}$ & $\begin{array}{l}\text { very } \\
\text { serious }^{\text {a }}\end{array}$ & not serious & not serious & not serious & none & $\begin{array}{l}8 \text { female adolescents aged } 15-17 \\
\text { ( } 3 \text { with AN, } 5 \text { with BN). SEED AN } \\
\text { and EDI maturity fears significantly } \\
\text { decreased from pre to post. Setting } \\
\text { was outpatient - } 2 \text { years } 1.5 \mathrm{~h} \text { per } \\
\text { week }\end{array}$ & $\begin{array}{l}\oplus \bigcirc \bigcirc \bigcirc \\
\text { VERY LOW }\end{array}$ & IMPORTANT \\
\hline
\end{tabular}

Explanations

ano control condition

Bibliography:

Case Report - Prestano 2008 [130]

review of 22 inpatients treated with olanzapine compared to an untreated age-matched group. The rate of weight gain was not significantly different, however, the treated group had more psychiatric co-morbidities than those not taking olanzapine and experienced side effects of sedation and dyslipidemia [139]. Hillebrand and colleagues [140] also reported on olanzapine use in seven patients (mean age 16.0 years) with AN. Most were taking $5 \mathrm{mg}$ of olanzapine, with one patient receiving $15 \mathrm{mg}$ once daily. The authors found reductions in activity levels in the adolescents taking olanzapine in comparison to 11 adolescents not treated with olanzapine. All patients were receiving either inpatient or day hospital care and there were no significant differences in weight [140].
In terms of case series, Leggero and colleagues [142] reported on 13 young patients (age 9.6 to 16.3 years) treated with a mean dose of $4.13 \mathrm{mg}$ daily of olanzapine. Significant improvements were seen in weight, functioning, eating disorder symptoms and hyperactivity. Similarly, Swenne and Rosling [141] reported on 47 adolescents with AN treated with a mean dose of $5.1 \mathrm{mg}$ daily. A mean weight gain of 9 $\mathrm{kg}$ was noted. The patients were treated for a mean of 228 days with olanzapine and were followed for three months following medication discontinuation. Biochemical side effects were closely monitored and were felt to be more related to refeeding processes than to medication [141].

Table 21 Dialectical behavioural therapy for eating disorders

\begin{tabular}{|c|c|c|c|c|c|c|c|c|c|}
\hline \multicolumn{7}{|c|}{ Certainty assessment } & \multirow[t]{2}{*}{ Impact } & \multirow[t]{2}{*}{ Certainty } & \multirow[t]{2}{*}{ Importance } \\
\hline $\begin{array}{l}\text { № of } \\
\text { studies }\end{array}$ & $\begin{array}{l}\text { Study } \\
\text { design }\end{array}$ & $\begin{array}{l}\text { Risk of } \\
\text { bias }\end{array}$ & Inconsistency & Indirectness & Imprecision & $\begin{array}{l}\text { Other } \\
\text { considerations }\end{array}$ & & & \\
\hline \multicolumn{10}{|c|}{ Binge Frequency (assessed with: number per month) Purge Frequency } \\
\hline \multirow[t]{3}{*}{2} & \multirow[t]{3}{*}{$\begin{array}{l}\text { Case } \\
\text { Series }\end{array}$} & $\begin{array}{l}\text { very } \\
\text { serious }\end{array}$ & not serious & not serious & not serious & none & $\begin{array}{l}\text { Two case series and one case } \\
\text { report for a total of } 22 \text { patients } \\
\text { (10 EDNOS, } 6 \text { AN, } 6 \text { BN) } \\
\text { reported a significant } \\
\text { decrease in binge frequency. } \\
\text { Reduction in vomiting pre and } \\
\text { post treatment. }\end{array}$ & $\begin{array}{l}\oplus \bigcirc \bigcirc \bigcirc \\
\text { VERY LOW }\end{array}$ & IMPORTANT \\
\hline & & $\begin{array}{l}\text { very } \\
\text { serious }^{a}\end{array}$ & not serious & not serious & not serious & none & $\begin{array}{l}\text { There were decreases in } \\
\text { psychological symptoms. }\end{array}$ & $\begin{array}{l}\oplus \bigcirc \bigcirc \bigcirc \\
\text { VERY LOW }\end{array}$ & IMPORTANT \\
\hline & & $\begin{array}{l}\text { very } \\
\text { serious }^{\text {a }}\end{array}$ & not serious & not serious & not serious & none & $\begin{array}{l}\text { A decrease in self harm also } \\
\text { noted. }\end{array}$ & $\begin{array}{l}\oplus \bigcirc \bigcirc \bigcirc \\
\text { VERY LOW }\end{array}$ & IMPORTANT \\
\hline \multicolumn{10}{|c|}{ Binge Frequency, EDE scores } \\
\hline \multirow[t]{2}{*}{1} & \multirow[t]{2}{*}{$\begin{array}{l}\text { Case } \\
\text { Report }\end{array}$} & $\begin{array}{l}\text { very } \\
\text { serious }^{a}\end{array}$ & not serious & not serious & not serious & none & $\begin{array}{l}N=1 \text { female with } B E D- \\
\text { decreased frequency of binge } \\
\text { episodes }\end{array}$ & $\begin{array}{l}\oplus \bigcirc \bigcirc \bigcirc \\
\text { VERY LOW }\end{array}$ & IMPORTANT \\
\hline & & $\begin{array}{l}\text { very } \\
\text { serious }\end{array}$ & not serious & not serious & not serious & none & improvement in EDE scores. & $\begin{array}{l}\oplus \bigcirc \bigcirc \bigcirc \\
\text { VERY LOW }\end{array}$ & IMPORTANT \\
\hline
\end{tabular}

Explanations

ano control group

Bibliography:

Case Series - Salbach-Andrae 2008 [133], Fischer 2015 [131]

Case Report - Safer 2007 [132] 
Table 22 Cognitive remediation therapy for children and adolescents with Anorexia Nervosa

\begin{tabular}{|c|c|c|c|c|c|c|c|c|c|}
\hline \multicolumn{7}{|c|}{ Certainty assessment } & \multirow[t]{2}{*}{ Impact } & \multirow[t]{2}{*}{ Certainty } & \multirow[t]{2}{*}{ Importance } \\
\hline $\begin{array}{l}\text { № of } \\
\text { studies }\end{array}$ & $\begin{array}{l}\text { Study } \\
\text { design }\end{array}$ & $\begin{array}{l}\text { Risk of } \\
\text { bias }\end{array}$ & Inconsistency & Indirectness & Imprecision & $\begin{array}{l}\text { Other } \\
\text { considerations }\end{array}$ & & & \\
\hline \multicolumn{10}{|c|}{ ART vs. CRT - Weight (assessed with: BMI), ED symptoms, depression, anxiety } \\
\hline \multirow[t]{4}{*}{1} & \multirow[t]{4}{*}{$\begin{array}{l}\text { randomised } \\
\text { trials }\end{array}$} & $\begin{array}{l}\text { not } \\
\text { serious }\end{array}$ & not serious & not serious & not serious & none & $\begin{array}{l}\text { RCT comparing Art Therapy } \\
\text { and CRT (both receiving FBT) } \\
n=30 \text { ( } 3 \text { male, } 27 \text { female). } \\
\text { BMI not significantly different. }\end{array}$ & $\begin{array}{l}\oplus \oplus \oplus \oplus \\
\mathrm{HIGH}\end{array}$ & CRITICAL \\
\hline & & $\begin{array}{l}\text { not } \\
\text { serious }\end{array}$ & not serious & not serious & not serious & none & $\begin{array}{l}\text { Art Therapy significantly better } \\
\text { than CRT in terms of global EDE } \\
\text { score at the end of } 15 \text { sessions. }\end{array}$ & $\begin{array}{l}\oplus \oplus \oplus \oplus \\
\mathrm{HIGH}\end{array}$ & CRITICAL \\
\hline & & $\begin{array}{l}\text { not } \\
\text { serious }\end{array}$ & not serious & not serious & not serious & none & $\begin{array}{l}\text { No difference between CRT and } \\
\text { Art Therapy with respect to } \\
\text { depression scores. }\end{array}$ & $\begin{array}{l}\oplus \oplus \oplus \oplus \\
\mathrm{HIGH}\end{array}$ & CRITICAL \\
\hline & & $\begin{array}{l}\text { not } \\
\text { serious }\end{array}$ & not serious & not serious & not serious & none & $\begin{array}{l}\text { No difference between CRT } \\
\text { and Art Therapy with respect } \\
\text { to Anxiety scores }\end{array}$ & $\begin{array}{l}\oplus \oplus \oplus \oplus \\
\mathrm{HIGH}\end{array}$ & CRITICAL \\
\hline \multicolumn{10}{|c|}{ Weight (assessed with: BMI), Depression (BDI), Anxiety (STAl) } \\
\hline \multirow[t]{3}{*}{1} & \multirow[t]{3}{*}{ Case Series } & $\begin{array}{l}\text { very } \\
\text { serious } a, b\end{array}$ & not serious & not serious & not serious & none & $\begin{array}{l}\text { One open trial of } 20 \text { patients } \\
\text { (10 inpatients, } 10 \text { outpatients) } \\
\text { describes weight improvement } \\
\text { with } 10 \text { sessions of CRT. Open } \\
\text { trial was pre post CRT. }\end{array}$ & $\begin{array}{l}\oplus \bigcirc \bigcirc \bigcirc \\
\text { VERY LOW }\end{array}$ & CRITICAL \\
\hline & & $\begin{array}{l}\text { very } \\
\text { serious }{ }^{a, b}\end{array}$ & not serious & not serious & not serious & none & $\begin{array}{l}\text { Depression scores decreased } \\
\text { significantly following CRT } \\
\text { (pre compared to post) }\end{array}$ & $\begin{array}{l}\oplus \bigcirc \bigcirc \bigcirc \\
\text { VERY LOW }\end{array}$ & CRITICAL \\
\hline & & $\begin{array}{l}\text { very } \\
\text { serious } a, b\end{array}$ & not serious & not serious & not serious & none & $\begin{array}{l}\text { No differences pre and post } \\
\text { were seen in terms of Anxiety. }\end{array}$ & $\begin{array}{l}\oplus \bigcirc \bigcirc \bigcirc \\
\text { VERY LOW }\end{array}$ & CRITICAL \\
\hline \multicolumn{10}{|l|}{ Weight } \\
\hline 1 & $\begin{array}{l}\text { Case } \\
\text { Report }\end{array}$ & $\begin{array}{l}\text { very } \\
\text { serious } a, b\end{array}$ & not serious & not serious & not serious & none & $\begin{array}{l}\text { Case report - } 12 \text { year old female } \\
\text { with AN - pre post and } 7 \text { month } \\
\text { follow up after } 10 \text { sessions CRT. } \\
\text { Weight improved at the follow } \\
\text { up assessment to a healthy } \\
\text { weight range. }\end{array}$ & $\begin{array}{l}\oplus \bigcirc \bigcirc \bigcirc \\
\text { VERY LOW }\end{array}$ & IMPORTANT \\
\hline
\end{tabular}

Explanations

${ }^{a}$ no control group

${ }^{b}$ no randomization

Bibliography:

RCT - Lock 2018 [65]

Case Series -Dahlgren 2013 [134]

Case Report - van Noort 2015 [135]

Thirteen case reports (Table 24) have also been published [42, 143-154]. Pisano and colleagues [143] reported on five cases of adolescents with AN treated with 2.5 to $7.5 \mathrm{mg}$ of olanzapine. At 6 month followup these patients demonstrated increased oral intake and improved BMI. Dennis, Le Grange, and Bremer [144] used olanzapine at a dose of $5 \mathrm{mg}$ daily in five adolescent females with AN and found an increase in BMI, reduction of body concerns, and improvements in sleep and anxiety surrounding food and weight. Another case series involving four young patients aged 10 to 12 years reported on the use of olanzapine at a dose of $2.5 \mathrm{mg}$ daily to treat AN [145]. These authors reported improvements in compliance and weight gain, as well as decreases in agitation. Mehler et al. [146] reported on five female patients aged 12 to 17 years on a dose range of $5 \mathrm{mg}$ to $12.5 \mathrm{mg}$ daily of olanzapine. They found improvements in body image distortion and rigidity. La Via, Gray, and Kaye [147] described two females with AN who experienced reduction of inner tension and "paranoid ideas" with use of $10 \mathrm{mg}$ daily of olanzapine. Finally, there is a case report using olanzapine $5 \mathrm{mg}$ daily to treat a 17 year old girl with AN and co-morbid pervasive developmental disorder not otherwise specified [150]. These authors reported weight restoration and improvements in eating behavior within 5 months of initiating treatment. 
Table 23 Yoga for eating disorders

\begin{tabular}{|c|c|c|c|c|c|c|c|c|c|}
\hline \multicolumn{7}{|c|}{ Certainty assessment } & \multirow[t]{2}{*}{ Impact } & \multirow[t]{2}{*}{ Certainty } & \multirow[t]{2}{*}{ Importance } \\
\hline $\begin{array}{l}\text { № of } \\
\text { studies }\end{array}$ & $\begin{array}{l}\text { Study } \\
\text { design }\end{array}$ & $\begin{array}{l}\text { Risk of } \\
\text { bias }\end{array}$ & Inconsistency & Indirectness & Imprecision & $\begin{array}{l}\text { Other } \\
\text { considerations }\end{array}$ & & & \\
\hline \multicolumn{10}{|c|}{ Psychological Symptoms (assessed with: EDE), weight, anxiety, depression } \\
\hline \multirow[t]{4}{*}{1} & $\begin{array}{l}\text { randomised } \\
\text { trials }\end{array}$ & $\begin{array}{l}\text { not } \\
\text { serious }\end{array}$ & not serious & not serious & not serious & none & $\begin{array}{l}\text { In this RCT } 50 \text { girls and } 4 \text { boys } \\
\text { were randomized to yoga plus } \\
\text { standard treatment, or standard } \\
\text { treatment alone.. There were no } \\
\text { differences in weight between the } \\
\text { yoga group and the no yoga } \\
\text { group at the end of the study. }\end{array}$ & $\begin{array}{l}\oplus \oplus \oplus \oplus \\
H I G H\end{array}$ & CRITICAL \\
\hline & & $\begin{array}{l}\text { not } \\
\text { serious }\end{array}$ & not serious & not serious & not serious & none & $\begin{array}{l}\text { The yoga group demonstrated } \\
\text { greater decreases in EDE score } \\
\text { at } 12 \text { weeks. }\end{array}$ & $\begin{array}{l}\oplus \oplus \oplus \oplus \\
\mathrm{HIGH}\end{array}$ & CRITICAL \\
\hline & & $\begin{array}{l}\text { not } \\
\text { serious }\end{array}$ & not serious & not serious & not serious & none & $\begin{array}{l}\text { Anxiety scores improved over } \\
\text { time in the yoga group and } \\
\text { were significantly improved } \\
\text { compared to the no yoga } \\
\text { group. }\end{array}$ & $\begin{array}{l}\oplus \oplus \oplus \oplus \\
\mathrm{HIGH}\end{array}$ & CRITICAL \\
\hline & & $\begin{array}{l}\text { not } \\
\text { serious }\end{array}$ & not serious & not serious & not serious & none & $\begin{array}{l}\text { Depression scores were } \\
\text { significantly improved in the } \\
\text { yoga group compared to the } \\
\text { control group. }\end{array}$ & $\begin{array}{l}\oplus \oplus \oplus \oplus \\
\mathrm{HIGH}\end{array}$ & CRITICAL \\
\hline
\end{tabular}

Bibliography:

RCT - Carei 2010 [136]

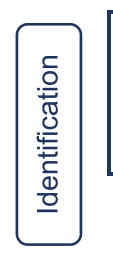

Records identified
through database

searchings

identified through other

$\mathrm{N}=236$

$\mathrm{N}=7$ ( 6 citation chaining

and 1 reference lists)

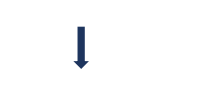

I

Records after duplicates removed $\mathrm{N}=202$

I

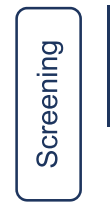

Records screened

$\mathrm{N}=202$

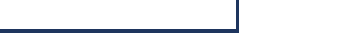

Records excluded $\mathrm{N}=97$

Not relevant -87

Full Text Not Retrievable - 10

Full-text articles excluded, with reasons $\mathrm{N}=73$

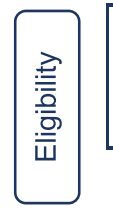

Full-text articles

assessed for eligibility

$\longrightarrow$

$\mathrm{N}=105$

Not children and adolescents -23

Not a treatment -7

Not eating disorders -31

Not primary study, systematic review or meta-analysis -2

No patient outcomes reported -10

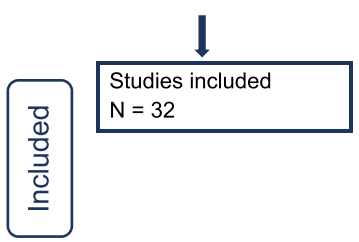

Fig. 3 PRISMA flow diagram for antipsychotics 
Table 24 Olanzapine for children and adolescents with Anorexia Nervosa

\begin{tabular}{|c|c|c|c|c|c|c|c|c|c|}
\hline \multicolumn{7}{|c|}{ Certainty assessment } & \multirow[t]{2}{*}{ Impact } & \multirow[t]{2}{*}{ Certainty } & \multirow[t]{2}{*}{ Importance } \\
\hline $\begin{array}{l}\text { № of } \\
\text { studies }\end{array}$ & $\begin{array}{l}\text { Study } \\
\text { design }\end{array}$ & $\begin{array}{l}\text { Risk of } \\
\text { bias }\end{array}$ & Inconsistency & Indirectness & Imprecision & $\begin{array}{l}\text { Other } \\
\text { considerations }\end{array}$ & & & \\
\hline \multicolumn{10}{|c|}{ Weight (assessed with: BMI), Psychological Symptoms, Side Effects } \\
\hline \multirow[t]{3}{*}{1} & \multirow[t]{3}{*}{$\begin{array}{l}\text { randomised } \\
\text { trials }\end{array}$} & $\begin{array}{l}\text { not } \\
\text { serious }\end{array}$ & not serious & not serious & not serious & none & $\begin{array}{l}\text { RCT with } 10 \text { subjects in olanzapine } \\
\text { group and } 10 \text { in placebo group. } \\
\text { No differences were found } \\
\text { between groups in rate of weight } \\
\text { restoration or final weight. } \\
\text { Difference in BMl was } 0.4 \mathrm{~kg} / \mathrm{m} 2 \\
\text { and was not significant. Mean } \\
\text { dose was } 8.5 \mathrm{mg} / \text { day. }\end{array}$ & $\begin{array}{l}\oplus \oplus \oplus \oplus \\
\mathrm{HIGH}\end{array}$ & CRITICAL \\
\hline & & $\begin{array}{l}\text { not } \\
\text { serious }\end{array}$ & not serious & not serious & not serious & none & $\begin{array}{l}\text { No differences in eating disorder } \\
\text { symptoms or psychological } \\
\text { functioning. }\end{array}$ & $\begin{array}{l}\oplus \oplus \oplus \oplus \\
\mathrm{HIGH}\end{array}$ & CRITICAL \\
\hline & & $\begin{array}{l}\text { not } \\
\text { serious }\end{array}$ & not serious & not serious & not serious & none & $\begin{array}{l}\text { A trend of increasing fasting } \\
\text { glucose and insulin levels were } \\
\text { found in the olanzapine group. }\end{array}$ & $\begin{array}{l}\oplus \oplus \oplus \oplus \\
\mathrm{HIGH}\end{array}$ & CRITICAL \\
\hline \multicolumn{10}{|c|}{ Weight gain, activity levels, side effects } \\
\hline \multirow[t]{3}{*}{3} & \multirow[t]{3}{*}{ Case Control } & serious $^{a}$ & not serious & not serious ${ }^{a}$ & not serious & none & $\begin{array}{l}\text { There are three non randomized } \\
\text { case control studies. One of the } \\
\text { studies found the rate of weight } \\
\text { gain was greater in the olanzapine } \\
\text { group, while another study found } \\
\text { no differences between cases and } \\
\text { controls in terms of weight gain. }\end{array}$ & $\begin{array}{l}\oplus \bigcirc \bigcirc \bigcirc \\
\text { VERY LOW }\end{array}$ & CRITICAL \\
\hline & & serious $^{a}$ & not serious & not serious $^{a}$ & not serious & none & $\begin{array}{l}\text { Reduced activity levels were } \\
\text { observed in one study. }\end{array}$ & $\begin{array}{l}\oplus \bigcirc \bigcirc \bigcirc \\
\text { VERY LOW }\end{array}$ & CRITICAL \\
\hline & & serious $^{a}$ & not serious & not serious ${ }^{a}$ & not serious & none & $\begin{array}{l}\text { Sedation and dyslipidemia was } \\
\text { found in } 56 \% \text { of patients in one } \\
\text { study. One study found that 32\% } \\
\text { of patients discontinued the } \\
\text { treatment due to a side effect. }\end{array}$ & $\begin{array}{l}\oplus \bigcirc \bigcirc \bigcirc \\
\text { VERY LOW }\end{array}$ & CRITICAL \\
\hline \multicolumn{10}{|c|}{ Weight, hyperactivity, side effects } \\
\hline \multirow[t]{3}{*}{2} & \multirow[t]{3}{*}{ Case Series } & $\begin{array}{l}\text { very } \\
\text { serious }^{\text {a }}\end{array}$ & not serious & not serious & not serious & none & $\begin{array}{l}60 \text { patients total involved in } \\
\text { these two case series. } \\
\text { Improvements in weight } \\
\text { noted. }\end{array}$ & $\begin{array}{l}\oplus \bigcirc \bigcirc \bigcirc \\
\text { VERY LOW }\end{array}$ & CRITICAL \\
\hline & & $\begin{array}{l}\text { very } \\
\text { serious }\end{array}$ & not serious & not serious & not serious & none & $\begin{array}{l}\text { Improvements in hyperactivity } \\
\text { are noted. }\end{array}$ & $\begin{array}{l}\oplus \bigcirc \bigcirc \bigcirc \\
\text { VERY LOW }\end{array}$ & CRITICAL \\
\hline & & $\begin{array}{l}\text { very } \\
\text { serious a }\end{array}$ & not serious & not serious & not serious & none & $\begin{array}{l}\text { No long term adverse effects } \\
\text { were seen } 3 \text { months after } \\
\text { discontinuing medication. }\end{array}$ & $\begin{array}{l}\oplus \bigcirc \bigcirc \bigcirc \\
\text { VERY LOW }\end{array}$ & CRITICAL \\
\hline \multicolumn{10}{|c|}{ Weight, side effects } \\
\hline \multirow[t]{2}{*}{13} & \multirow[t]{2}{*}{$\begin{array}{l}\text { Case } \\
\text { Reports }\end{array}$} & $\begin{array}{l}\text { very } \\
\text { serious }^{\text {a }}\end{array}$ & not serious & not serious & not serious & none & $\begin{array}{l}\text { Thirteen studies report on } 30 \\
\text { cases. All studies report } \\
\text { improvement in weight. }\end{array}$ & $\begin{array}{l}\oplus \bigcirc \bigcirc \bigcirc \\
\text { VERY LOW }\end{array}$ & CRITICAL \\
\hline & & $\begin{array}{l}\text { very } \\
\text { serious a }\end{array}$ & not serious & not serious & not serious & none & $\begin{array}{l}\text { One case study reports on } \\
\text { QTc prolongation (a problem } \\
\text { on the ECG), another reports } \\
\text { a case with neuroleptic } \\
\text { malignant syndrome. }\end{array}$ & $\begin{array}{l}\oplus \bigcirc \bigcirc \bigcirc \\
\text { VERY LOW }\end{array}$ & CRITICAL \\
\hline
\end{tabular}

\section{Explanations}

abservational study, non randomized

Bibliography:

RCT - Kafantaris 2011 [137]

Case Control - Spettigue 2018 [138], Norris 2011 [139], Hillebrand 2005 [140]

Case Series -Swenne 2011 [141], Leggero 2010 [142]

Case Reports - Pisano 2014 [143], Duvvuri 2012 [42], Dennis 2006 [144], Boachie 2003 [145], Mehler 2001 [146], La Via 2000 [147],

Dadic-Hero 2009 [148], Hein 2010 [149], Tateno 2008 [150], Ercan 2003 [151], Dodig-Curkovic 2010 [152], Ayyildiz 2016 [153], Ritchie 2009 [154] 
Table 25 Olanzapine for children and adolescents with OSFED/EDNOS

\begin{tabular}{|c|c|c|c|c|c|c|c|c|c|}
\hline \multicolumn{7}{|c|}{ Certainty assessment } & \multirow[t]{2}{*}{ Impact } & \multirow[t]{2}{*}{ Certainty } & \multirow[t]{2}{*}{ Importance } \\
\hline $\begin{array}{l}\text { № of } \\
\text { studies }\end{array}$ & $\begin{array}{l}\text { Study } \\
\text { design }\end{array}$ & $\begin{array}{l}\text { Risk of } \\
\text { bias }\end{array}$ & Inconsistency & Indirectness & Imprecision & $\begin{array}{l}\text { Other } \\
\text { considerations }\end{array}$ & & & \\
\hline \multicolumn{10}{|c|}{ Global improvement (assessed with: Clinical Global Impressions Scale) } \\
\hline 1 & $\begin{array}{l}\text { Case } \\
\text { Report }\end{array}$ & $\begin{array}{l}\text { very } \\
\text { serious }^{a}\end{array}$ & not serious & serious $^{b}$ & not serious & none & $\begin{array}{l}\text { Single case report of } 12 \text { year } \\
\text { old female with EDNOS. CGl } \\
\text { improved with olanzapine } \\
10 \text { mg daily. }\end{array}$ & $\begin{array}{l}\oplus \bigcirc \bigcirc \bigcirc \\
\text { VERY LOW }\end{array}$ & IMPORTANT \\
\hline
\end{tabular}

Explanations

asingle case report, no control

boutcome measured does not really answer our clinical question

Bibliography:

Case Report - Bozabali 2002 [156]

Eating disorder not otherwise specified Olanzapine was used in a case report of a 12 year old female with EDNOS with improvements on the clinical global impressions scale at a dose of $10 \mathrm{mg}$ daily [156] (Table 25).

Avoidant/restrictive food intake disorder In a recent case series, Spettigue and colleagues [53] described six patients with ARFID and co-morbid anxiety (median age 12.9 years) who were treated with a combination of family therapy plus pharmacotherapy (Table 26). All patients were treated with olanzapine in combination with other medications, making interpretation of the results difficult: three cases were treated with a combination of olanzapine and fluoxetine, one case was treated with olanzapine followed by fluvoxamine, and two cases were treated with a combination of olanzapine, cyproheptadine and fluoxetine. All six cases reached their treatment goal weights.

Another recent case series reported beneficial effects from olanzapine in the treatment of patients with ARFID [157]. These authors completed a retrospective chart review and described a significant increase in weight, as well as improvements in anxiety and depressive symptoms in nine patients with ARFID treated with olanzapine. The mean final dose of olanzapine was $2.8 \mathrm{mg}$ daily. All nine patients had comorbid mental health diagnoses including separation

Table 26 Olanzapine for children and adolescents with avoidant/restrictive food intake disorder

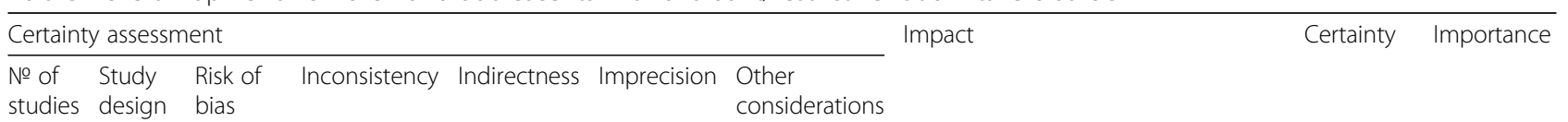

Weight (assessed with: Ibs), Anxious/Depressive Symptoms

2 Case very not serious not serious not serious none

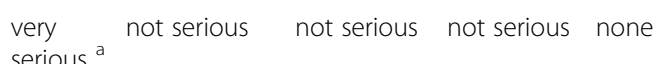

$N=15$ total in two studies. Nine patients aged 9-19years in this prepost- study. Rate of weight gain increased significantly with olanzapine treatment from 3.3lbs to $13.1 \mathrm{lbs}$. All patients were in a residential treatment facility. Another case series of 6 patients indicated all patients gained to their target weight with olanzapine (2.5 to 7.5 mg daily) in combination with SSRIs and family therapy.

The Clinical global impressions scale was used to rate anxious/depressive symptoms for 9 patients pre and post. The rating changed from markedly ill to mildly ill. All patients were in a residential treatment facility.

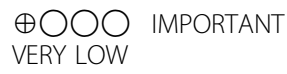


Table 27 Risperidone for children and adolescents with anorexia nervosa

\begin{tabular}{|c|c|c|c|c|c|c|c|c|c|}
\hline \multicolumn{7}{|c|}{ Certainty assessment } & \multirow[t]{2}{*}{ Impact } & \multirow[t]{2}{*}{ Certainty } & \multirow[t]{2}{*}{ Importance } \\
\hline $\begin{array}{l}\text { № of } \\
\text { studies }\end{array}$ & $\begin{array}{l}\text { Study } \\
\text { design }\end{array}$ & $\begin{array}{l}\text { Risk of } \\
\text { bias }\end{array}$ & Inconsistency & Indirectness & Imprecision & $\begin{array}{l}\text { Other } \\
\text { considerations }\end{array}$ & & & \\
\hline \multicolumn{10}{|c|}{ Weight (assessed with: kg), Psychological Symtpoms, Side Effects } \\
\hline \multirow[t]{3}{*}{1} & \multirow[t]{3}{*}{$\begin{array}{l}\text { randomised } \\
\text { trials }\end{array}$} & $\begin{array}{l}\text { not } \\
\text { serious }\end{array}$ & not serious & not serious & not serious & none & $\begin{array}{l}\text { There were no significant } \\
\text { differences in weight at end of } \\
\text { study (risperidone } n=18 \text {, placebo } \\
n=22 \text { ). Even when just data from } \\
\text { those under age } 18 \text { (placebo 18, } \\
\text { risperidone } 12 \text { ) were analyzed } \\
\text { separately, there were no } \\
\text { differences. Mean dose } 2.5 \mathrm{mg} \\
\text { over } 9 \text { weeks. }\end{array}$ & $\begin{array}{l}\oplus \oplus \oplus \oplus \\
\mathrm{HIGH}\end{array}$ & CRITICAL \\
\hline & & $\begin{array}{l}\text { not } \\
\text { serious }\end{array}$ & not serious & not serious & not serious & none & $\begin{array}{l}\text { There were no significant } \\
\text { differences at end of study on } \\
\text { any subscale of the EDI (Eating } \\
\text { Disorders Inventory). }\end{array}$ & $\begin{array}{l}\oplus \oplus \oplus \oplus \\
\mathrm{HIGH}\end{array}$ & CRITICAL \\
\hline & & $\begin{array}{l}\text { not } \\
\text { serious }\end{array}$ & not serious & not serious & not serious & none & $\begin{array}{l}\text { ECG, bloodwork (prolactin, lipids, } \\
\text { liver enzymes, glucose) no } \\
\text { differences. Patient in the treated } \\
\text { group reported fatigue and } \\
\text { dizziness. }\end{array}$ & $\begin{array}{l}\oplus \oplus \oplus \oplus \\
\mathrm{HIGH}\end{array}$ & CRITICAL \\
\hline \multicolumn{10}{|c|}{ Weight (assessed with: kg), Psychological Symptoms } \\
\hline \multirow[t]{2}{*}{4} & \multirow[t]{2}{*}{$\begin{array}{l}\text { Case } \\
\text { Reports }\end{array}$} & $\begin{array}{l}\text { very } \\
\text { serious a }\end{array}$ & not serious & not serious & serious $^{a}$ & none & $\begin{array}{l}\text { Weight generally increased pre } \\
\text { to post study period by several } \\
\mathrm{kg} \text { in } 4 \text { cases. }\end{array}$ & $\begin{array}{l}\oplus \bigcirc \bigcirc \bigcirc \\
\text { VERY LOW }\end{array}$ & CRITICAL \\
\hline & & $\begin{array}{l}\text { very } \\
\text { serious a }\end{array}$ & not serious & not serious & serious $^{a}$ & none & $\begin{array}{l}\text { Psychological symptoms } \\
\text { including willingness to eat } \\
\text { improved over the study period. } \\
\text { Rigidity decreased. }(n=4)\end{array}$ & $\begin{array}{l}\oplus \bigcirc \bigcirc \bigcirc \\
\text { VERY LOW }\end{array}$ & CRITICAL \\
\hline
\end{tabular}

\section{Explanations}

${ }^{a}$ These are four case reports with no comparison condition

Bibliography:

RCT - Hagman 2011 [158]

Case Reports - Fisman 1996 [159], Kracke 2014 [160], Umehara 2014 [161], Newman-Toker 2000 [162]

anxiety, obsessive-compulsive disorder, posttraumatic stress disorder, generalized anxiety disorder, and social anxiety disorder. Six of the nine also had significant major depressive symptoms.

\section{Risperidone}

Anorexia nervosa The use of risperidone for AN has been studied in one high quality RCT and four case reports (Table 27). Hagman and colleagues [158] conducted a double-blind placebo-controlled trial of risperidone in adolescents and young adults with AN (age range 12 to 21 years). These authors randomized 40 patients to risperidone or placebo. The mean dose of risperidone was $2.5 \mathrm{mg}$ daily over a mean duration of 9 weeks. There were no differences found between the groups at the end of the study [158]. Personal communication with the primary author indicates that even when the subgroup of patients under age 18 years was examined, no differences were found. These authors concluded that their results do not support the use of risperidone in the weight restoration phase of treatment for young patients with AN [158].

Four case reports were found on the use of risperidone in the treatment of AN [159-162]. Weight generally increased in all four cases described, and willingness to eat increased. Of these was a case report of a 12 year old girl with autism and AN who is described as benefitting from treatment with risperidone at a dose of $0.5 \mathrm{mg}$ twice daily [159]. One of these cases describes the use of risperidone longacting injection [161].

Avoidant/restrictive food intake disorder Pennell and colleagues [163] described two cases of ARFID where significant weight loss occurred with stimulant treatment for Attention Deficit Hyperactivity Disorder (ADHD), resulting in the need for hospitalization. These cases were managed by temporarily stopping the stimulant and adding risperidone to help with appetite and behaviour (Table 28). 
Table 28 Risperidone for children and adolescents with avoidant/restrictive food intake disorder

\begin{tabular}{|c|c|c|c|c|c|c|c|c|c|}
\hline \multicolumn{7}{|c|}{ Certainty assessment } & \multirow[t]{2}{*}{ Impact } & \multirow[t]{2}{*}{ Certainty } & \multirow[t]{2}{*}{ Importance } \\
\hline $\begin{array}{l}\text { № of } \\
\text { studies }\end{array}$ & $\begin{array}{l}\text { Study } \\
\text { design }\end{array}$ & $\begin{array}{l}\text { Risk of } \\
\text { bias }\end{array}$ & Inconsistency & Indirectness & Imprecision & $\begin{array}{l}\text { Other } \\
\text { considerations }\end{array}$ & & & \\
\hline \multicolumn{10}{|c|}{ Weight, psychological symptoms } \\
\hline \multirow[t]{2}{*}{1} & $\begin{array}{l}\text { Case } \\
\text { Report }\end{array}$ & $\begin{array}{l}\text { very } \\
\text { serious }^{a}\end{array}$ & not serious & not serious & not serious & none & $\begin{array}{l}\text { In two cases of ARFID on dose } \\
\text { of } 1 \mathrm{mg} \text { daily of risperidone. } \\
\text { Weight gain was observed to } \\
\text { target weight over several } \\
\text { weeks. }\end{array}$ & $\begin{array}{l}\oplus \bigcirc \bigcirc \bigcirc \\
\text { VERY LOW }\end{array}$ & IMPORTANT \\
\hline & & $\begin{array}{l}\text { very } \\
\text { serious }^{\text {a }}\end{array}$ & not serious & not serious & not serious & none & $\begin{array}{l}\text { Oppositional behaviour and } \\
\text { rigidity around eating improved. }\end{array}$ & $\begin{array}{l}\oplus \bigcirc \bigcirc \bigcirc \\
\text { VERY LOW }\end{array}$ & IMPORTANT \\
\hline
\end{tabular}

Explanations

atwo case reports with no control group

Bibliography:

Case Report - Pennell 2016 [163]

\section{Quetiapine}

Anorexia nervosa Very few studies could be found on the treatment of AN with quetiapine (Table 29). One case series described quetiapine use in three subjects, aged 11 to 15 years with severe AN (lengthy hospitalization, use of nasogastric tubes, and BMI 12.3 to 13.9) [164]. Two of these patients were treated with quetiapine $100 \mathrm{mg}$ twice daily, and one patient was treated with $250 \mathrm{mg}$ twice daily. Authors reported improvements in body image disturbance, weight phobia, and "paranoid ideas". Sedation and constipation were noted as side effects.

\section{Aripiprazole}

Anorexia nervosa One case control study and two case reports were found on the use of aripiprazole in AN (Table 30). Frank and colleagues completed a retrospective case control study [165] and a case report [166] on the use of aripiprazole in adolescents with AN. The chart review described 22 adolescents with AN taking aripiprazole at a mean dose of $3.59 \mathrm{mg}$ daily compared to an untreated comparison group of 84 adolescents with AN. These authors found a greater increase in BMI in the treated group [165]. The case report described four adolescents who benefitted in terms of weight and improved eating disorder cognitions [166]. One other case report was found on the use of aripiprazole [167]. The adolescent received a dose of $5 \mathrm{mg}$ daily. The authors report an improvement in anxiety and rigidity around eating with aripiprazole.

Avoidant/restrictive food intake disorder One case report described the beneficial use of fluoxetine $(20 \mathrm{mg}$ daily) in combination with aripiprazole ( $2.5 \mathrm{mg}$ daily) for a 15 year old girl with severe choking phobia [168] (Table 31).

\section{Antidepressants}

Nine hundred and ninety-six abstracts were identified through our database searches along with six additional articles through citation chaining and reference list searching for the antidepressant section of our guideline (see PRISMA flow diagram Fig. 4). Six hundred and fifty-seven citations were excluded on screening. On full text review, 197 articles were excluded, leaving 19 papers for data extraction.

Table 29 Quetiapine for children and adolescents with Anorexia Nervosa

\begin{tabular}{|c|c|c|c|c|c|c|c|c|c|}
\hline \multicolumn{7}{|c|}{ Certainty assessment } & \multirow[t]{2}{*}{ Impact } & \multirow[t]{2}{*}{ Certainty } & \multirow[t]{2}{*}{ Importance } \\
\hline $\begin{array}{l}\text { № of } \\
\text { studies }\end{array}$ & $\begin{array}{l}\text { Study } \\
\text { design }\end{array}$ & $\begin{array}{l}\text { Risk of } \\
\text { bias }\end{array}$ & Inconsistency & Indirectness & Imprecision & $\begin{array}{l}\text { Other } \\
\text { considerations }\end{array}$ & & & \\
\hline \multicolumn{10}{|c|}{ Weight, fear of weight gain, side effects } \\
\hline \multirow[t]{3}{*}{1} & $\begin{array}{l}\text { Case } \\
\text { Report }\end{array}$ & $\begin{array}{l}\text { very } \\
\text { serious }^{a}\end{array}$ & not serious & not serious & not serious & none & $\begin{array}{l}\text { Three cases described in } \\
\text { which weight increased. }\end{array}$ & $\begin{array}{l}\oplus \bigcirc \bigcirc \bigcirc \\
\text { VERY LOW }\end{array}$ & CRITICAL \\
\hline & & $\begin{array}{l}\text { very } \\
\text { serious }^{a}\end{array}$ & not serious & not serious & not serious & none & $\begin{array}{l}\text { Fear of weight gain } \\
\text { improved. }\end{array}$ & $\begin{array}{l}\oplus \bigcirc \bigcirc \bigcirc \\
\text { VERY LOW }\end{array}$ & CRITICAL \\
\hline & & $\begin{array}{l}\text { very } \\
\text { serious }^{a}\end{array}$ & not serious & not serious & not serious & none & $\begin{array}{l}\text { Side effects - Initial Fatigue, } \\
\text { constipation. }\end{array}$ & $\begin{array}{l}\oplus \bigcirc \bigcirc \bigcirc \\
\text { VERY LOW }\end{array}$ & CRITICAL \\
\hline
\end{tabular}

Explanations

athis a series of three cases with no control group

Bibliography:

Case Report - Mehler-Wex 2008 [164] 
Table 30 Aripiprazole for children and adolescents with Anorexia Nervosa

\begin{tabular}{|c|c|c|c|c|c|c|c|c|c|}
\hline \multicolumn{7}{|c|}{ Certainty assessment } & \multirow[t]{2}{*}{ Impact } & \multirow[t]{2}{*}{ Certainty } & \multirow[t]{2}{*}{ Importance } \\
\hline $\begin{array}{l}\text { № of } \\
\text { studies }\end{array}$ & $\begin{array}{l}\text { Study } \\
\text { design }\end{array}$ & $\begin{array}{l}\text { Risk of } \\
\text { bias }\end{array}$ & Inconsistency & Indirectness & Imprecision & $\begin{array}{l}\text { Other } \\
\text { considerations }\end{array}$ & & & \\
\hline \multicolumn{10}{|l|}{ Weight } \\
\hline 1 & $\begin{array}{l}\text { Case } \\
\text { Control }\end{array}$ & serious $^{a}$ & not serious & not serious & not serious & none & $\begin{array}{l}\text { Retrospective case-control study } \\
\text { with } 22 \text { subjects treated with } \\
\text { aripiprazole, } 84 \text { no treatment. } \\
\text { BMI was slightly different } \\
\text { between groups } 18.8 \text { vs. } 17.9 \\
p<0.35 \text {. }\end{array}$ & $\begin{array}{l}\oplus \bigcirc \bigcirc \bigcirc \\
\text { VERY LOW }\end{array}$ & CRITICAL \\
\hline \multicolumn{10}{|l|}{ Weight } \\
\hline 2 & $\begin{array}{l}\text { Case } \\
\text { Reports }\end{array}$ & $\begin{array}{l}\text { very } \\
\text { serious }\end{array}$ & not serious & not serious & not serious & none & $\begin{array}{l}5 \text { cases report a benefit in terms } \\
\text { of weight gain }\end{array}$ & $\begin{array}{l}\oplus \bigcirc \bigcirc \bigcirc \\
\text { VERY LOW }\end{array}$ & CRITICAL \\
\hline
\end{tabular}

Explanations

athe study was not randomized

$b_{\text {there }}$ are five cases reported on in total with no comparison group

Bibliography:

Case Control - Frank 2017 [165]

Case Reports - Frank 2016 [166], Trunko 2011 [167]

\section{Selective serotonin reuptake inhibitors}

Anorexia nervosa In terms of Selective Serotonin Reuptake Inhibitors (SSRIs) for AN, one case control study and five case reports were found (Table 32). One retrospective study compared 19 adolescent patients with AN taking SSRIs to 13 patients with $\mathrm{AN}$ not treated with SSRIs [169]. These authors found no differences between groups in terms of BMI, eating disorder psychopathology, or depressive and obsessive-compulsive symptoms after evaluating patients on admission, discharge and one-year follow-up. The SSRIs involved in this study included fluoxetine ( $n=7$, mean dose $35 \mathrm{mg}$ daily), fluvoxamine $(n=8$, mean dose $120 \mathrm{mg}$ daily), and sertraline ( $n=4$, mean dose $100 \mathrm{mg}$ daily).

Five adolescent case reports have been published on the use of SSRIs in AN. One of these focused on the use of sertraline in an adolescent with $\mathrm{AN}$ and symptoms of purging [170], another on the use of fluoxetine in an adolescent with AN and depressive features [171], and another on the use of fluoxetine for comorbid obsessive compulsive disorder [172]. All of these cases described a benefit in terms of anxiety, mood and weight restoration. Two additional case reports examined SSRIs in combination with antipsychotics [151, 162]. Newman-Toker [162] described two cases of adolescents with AN in which risperidone ( $1.5 \mathrm{mg}$ daily) was added to antidepressant treatment, with improvements in anxiety and weight gain. Similarly, Ercan and colleagues [151] described a case of a 15 year old female with severe AN treated with olanzapine, fluoxetine, alprazolam, and thioridazine, demonstrating that polypharmacy is sometimes needed for severe symptoms of AN including agitation and fear of weight gain. These authors also reported that once stabilized in terms of agitation, a maintenance dose of $10 \mathrm{mg}$ of olanzapine daily resulted in an

Table 31 Aripiprazole for children and adolescents with avoidant/restrictive food intake disorder

\begin{tabular}{|c|c|c|c|c|c|c|c|c|c|}
\hline \multicolumn{7}{|c|}{ Certainty assessment } & \multirow[t]{2}{*}{ Impact } & \multirow[t]{2}{*}{ Certainty } & \multirow[t]{2}{*}{ Importance } \\
\hline $\begin{array}{l}\text { № of } \\
\text { studies }\end{array}$ & $\begin{array}{l}\text { Study } \\
\text { design }\end{array}$ & Risk of bias & Inconsistency & Indirectness & Imprecision & $\begin{array}{l}\text { Other } \\
\text { considerations }\end{array}$ & & & \\
\hline \multicolumn{10}{|c|}{ Weight (assessed with: kg), psychological Symptoms } \\
\hline \multirow[t]{2}{*}{1} & $\begin{array}{l}\text { Case } \\
\text { Report }\end{array}$ & $\begin{array}{l}\text { very } \\
\text { serious }^{a}\end{array}$ & not serious & not serious & not serious & none & $\begin{array}{l}\text { Only one case report. } \\
\text { Patient gained } 10 \mathrm{~kg} \text {. } \\
\text { Also on fluoxetine. }\end{array}$ & $\begin{array}{l}\oplus \bigcirc \bigcirc \bigcirc \\
\text { VERY LOW }\end{array}$ & IMPORTANT \\
\hline & & $\begin{array}{l}\text { very } \\
\text { serious }\end{array}$ & not serious & not serious & not serious & none & $\begin{array}{l}\text { Psychological symptoms } \\
\text { including anxiety and } \\
\text { rigidity improved. }\end{array}$ & $\begin{array}{l}\oplus \bigcirc \bigcirc \bigcirc \\
V E R Y L O W\end{array}$ & IMPORTANT \\
\hline
\end{tabular}

Explanations

aone case report, no comparison

Bibliography:

Case Report - Sivri 2018 [168] 


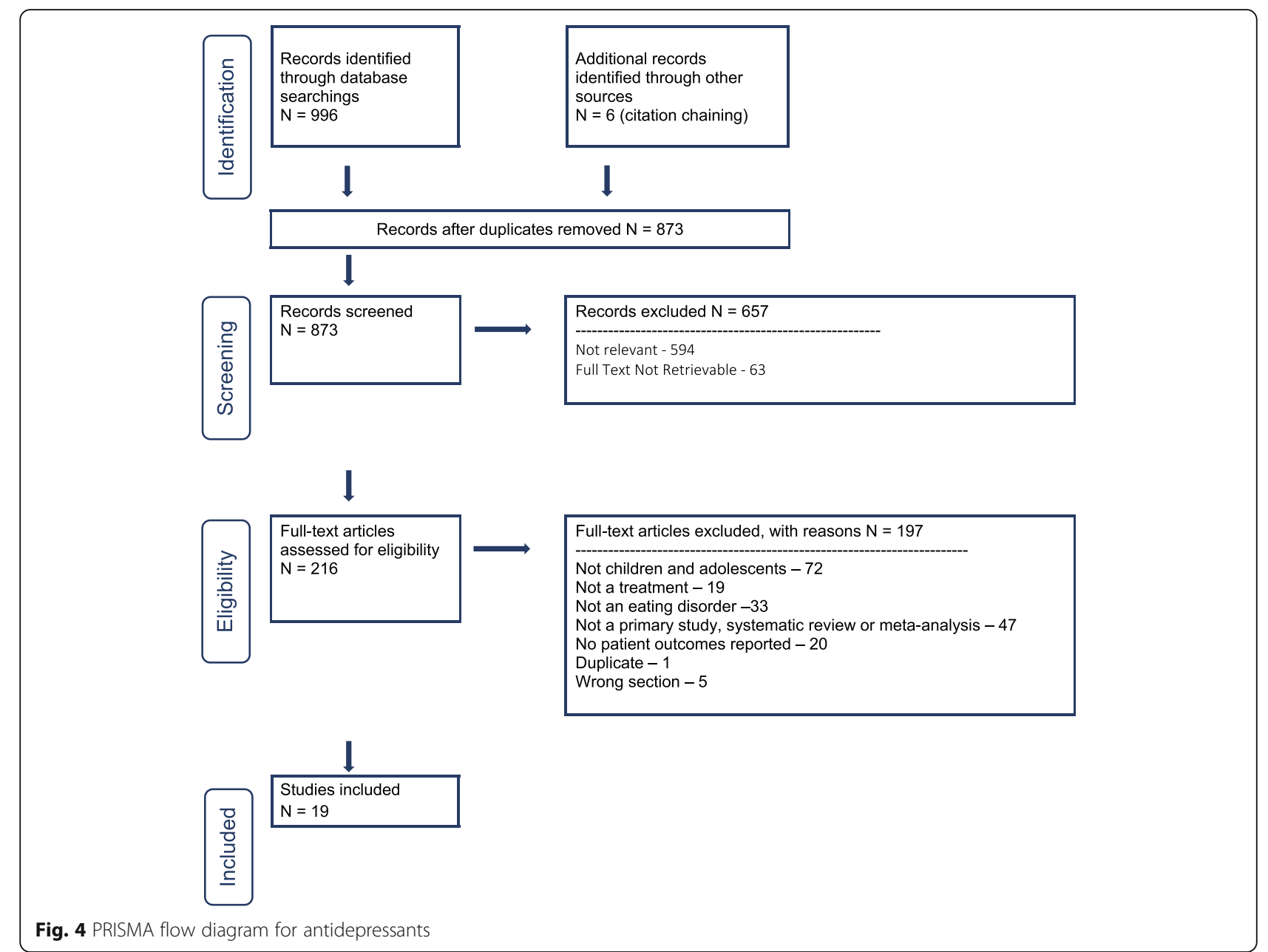

increase in BMI, along with a reduction of obsessivecompulsive symptoms, exercising, and eating disorder cognitions [151].

Bulimia nervosa Selective serotonin reuptake inhibitors have been studied in children and youth with BN, although the evidence is scant (Table 33). One open trial of fluoxetine in ten adolescents aged 12 to 18 years [173] reported on 8 weeks of a titrating dose of fluoxetine (maximum $60 \mathrm{mg}$ daily) along with supportive psychotherapy. Frequencies of binge episodes decreased significantly from a mean of 4.1 to zero episodes per week, and weekly purges decreased from 6.4 to 0.4 episodes per week [173]. Seventy percent of patients were rated as improved or much improved on the clinical global impressions-improvement scale. No significant side effects were noted. Whether patients maintained these benefits over the long term is unknown.

One case report describes the use of valproate $200 \mathrm{mg}$ twice daily following onset of mania felt to be related to the use of fluoxetine in an adolescent female with $\mathrm{BN}$. In this report mood stabilized and binge eating and purging symptoms resolved once the fluoxetine had been stopped and valproate was initiated [174].

Other specified feeding and eating disorders Our review identified one case report of a patient with Other Specified Feeding and Eating Disorder (OSFED), atypical AN, whose depressive symptoms were treated with escitalopram with improvement noted [175]. She had lost almost $40 \mathrm{~kg}$ over a period of 4 months, but remained within a normal weight range (Table 34). Body image concerns remained.

Avoidant/restrictive food intake disorder In terms of the 'post-traumatic' subtype of ARFID where there has been a choking event followed by refusal to eat and drink, the SSRIs have been described in case reports as being helpful (Table 35). Several SSRIs have been mentioned in case reports including; escitalopram [177] and fluoxetine $[120,178]$. Of note, Celik and colleagues reported a case of two 2-year old twins who were treated with fluoxetine $5 \mathrm{mg}$ daily for a severe posttraumatic food avoidance, with good effect [178]. Similarly, a case 
Table 32 SSRIs for children and adolescents with Anorexia Nervosa

\begin{tabular}{|c|c|c|c|c|c|c|c|c|c|}
\hline \multicolumn{7}{|c|}{ Certainty assessment } & \multirow[t]{2}{*}{ Impact } & \multirow[t]{2}{*}{ Certainty } & \multirow[t]{2}{*}{ Importance } \\
\hline $\begin{array}{l}\text { № of } \\
\text { studies }\end{array}$ & $\begin{array}{l}\text { Study } \\
\text { design }\end{array}$ & $\begin{array}{l}\text { Risk of } \\
\text { bias }\end{array}$ & Inconsistency & Indirectness & Imprecision & $\begin{array}{l}\text { Other } \\
\text { considerations }\end{array}$ & & & \\
\hline \multicolumn{10}{|c|}{ Weight (assessed with: BMI), Core Eating disorder Symptoms (assessed with: ANIS), Depression (assessed with: DIJK) } \\
\hline \multirow[t]{4}{*}{1} & \multirow[t]{4}{*}{$\begin{array}{l}\text { Case } \\
\text { Control }\end{array}$} & serious $^{a}$ & not serious & not serious & not serious & none & $\begin{array}{l}\text { Retrospective chart review - } 19 \\
\text { patients on SSRIs ( } 7 \text { fluoxetine } \\
20-60 \text { mg, } 8 \text { fluvoxamine 100-150 } \\
\text { mg, } 4 \text { sertraline } 50-150 \text { mg) } \\
\text { compared to } 13 \text { on no medication. } \\
\text { No differences in BMI. }\end{array}$ & $\begin{array}{l}\oplus \bigcirc \bigcirc \bigcirc \\
\text { VERY LOW }\end{array}$ & CRITICAL \\
\hline & & serious $^{a}$ & not serious & not serious & not serious & none & $\begin{array}{l}\text { No differences in core ED } \\
\text { pathology. }\end{array}$ & $\begin{array}{l}\oplus \bigcirc \bigcirc \bigcirc \\
\text { VERY LOW }\end{array}$ & CRITICAL \\
\hline & & serious $^{a}$ & not serious & not serious & not serious & none & $\begin{array}{l}\text { No difference in depression scores } \\
\text { between treated and untreated } \\
\text { groups. }\end{array}$ & $\begin{array}{l}\oplus \bigcirc \bigcirc \bigcirc \\
\text { VERY LOW }\end{array}$ & CRITICAL \\
\hline & & serious $^{a}$ & not serious & not serious & not serious & none & $\begin{array}{l}\text { No difference in obsessive } \\
\text { compulsive symptoms between } \\
\text { treated and untreated groups. }\end{array}$ & $\begin{array}{l}\oplus \bigcirc \bigcirc \bigcirc \\
\text { VERY LOW }\end{array}$ & CRITICAL \\
\hline \multicolumn{10}{|c|}{ Weight (assessed with: kg) } \\
\hline 5 & $\begin{array}{l}\text { Case } \\
\text { Reports }\end{array}$ & $\begin{array}{l}\text { very } \\
\text { serious } a, b\end{array}$ & not serious & not serious & not serious & none & $\begin{array}{l}\text { Five case reports ( } 3 \text { fluoxetine } \\
20 \mathrm{mg}, 2 \text { sertraline } 75-100 \mathrm{mg} \text { ) are } \\
\text { described in which patients had a } \\
\text { good response to various SSRIs } \\
\text { and gained weight. }\end{array}$ & $\begin{array}{l}\oplus \bigcirc \bigcirc \bigcirc \\
\text { VERY LOW }\end{array}$ & CRITICAL \\
\hline
\end{tabular}

\section{Explanations}

${ }^{\mathrm{a}}$ Non randomized study

${ }^{\mathrm{b}}$ No control condition

Bibliography:

Case Control - Holtkamp 2005 [169]

Case Report - Frank 2001 [170], Newman Toker 2000 [162], Lyles 1990 [171], Ercan 2003 [151], Gee 1999 [172]

Table 33 SSRIs for children and adolescents with Bulimia Nervosa

\begin{tabular}{|c|c|c|c|c|c|c|c|c|c|}
\hline \multicolumn{7}{|c|}{ Certainty assessment } & \multirow[t]{2}{*}{ Impact } & \multirow[t]{2}{*}{ Certainty } & \multirow[t]{2}{*}{ Importance } \\
\hline $\begin{array}{l}\text { № of } \\
\text { studies }\end{array}$ & $\begin{array}{l}\text { Study } \\
\text { design }\end{array}$ & $\begin{array}{l}\text { Risk of } \\
\text { bias }\end{array}$ & Inconsistency & Indirectness & Imprecision & $\begin{array}{l}\text { Other } \\
\text { considerations }\end{array}$ & & & \\
\hline \multicolumn{10}{|c|}{ Binge Frequency (assessed with: average weekly binges), purge frequency, psychological symptoms, depression (BDI) } \\
\hline \multirow[t]{3}{*}{1} & \multirow[t]{3}{*}{$\begin{array}{l}\text { Case } \\
\text { Series }\end{array}$} & $\begin{array}{l}\text { very } \\
\text { serious a }\end{array}$ & not serious & not serious & not serious & none & $\begin{array}{l}\text { Ten subjects all female, no control } \\
\text { group. } 8 \text { week study of fluoxetine } \\
60 \mathrm{mg} / \text { day. Binge frequency } \\
\text { decreased from } 4.1 \text { to } 3.8(p<0.01) \text {. } \\
\text { Purge frequency decreased from } 6.4 \\
\text { to } 5.2(p<0.005) \text {. }\end{array}$ & $\begin{array}{l}\oplus \bigcirc \bigcirc \bigcirc \\
\text { VERY LOW }\end{array}$ & CRITICAL \\
\hline & & $\begin{array}{l}\text { very } \\
\text { serious }^{a}\end{array}$ & not serious & not serious & not serious & none & $\begin{array}{l}\text { EDI Bulimia Subscale decreased } \\
\text { significantly from } 10.6 \text { to } 4.2(P< \\
0.01) \text {. }\end{array}$ & $\begin{array}{l}\oplus \bigcirc \bigcirc \bigcirc \\
\text { VERY LOW }\end{array}$ & CRITICAL \\
\hline & & $\begin{array}{l}\text { very } \\
\text { serious a }\end{array}$ & not serious & not serious & not serious & none & $\begin{array}{l}\text { BDI scores were not significantly } \\
\text { different pre and post. }\end{array}$ & $\begin{array}{l}\oplus \bigcirc \bigcirc \bigcirc \\
\text { VERY LOW }\end{array}$ & CRITICAL \\
\hline \multicolumn{10}{|c|}{ Adverse Effect - Mania } \\
\hline 1 & $\begin{array}{l}\text { Case } \\
\text { Report }\end{array}$ & $\begin{array}{l}\text { very } \\
\text { serious } a, b\end{array}$ & not serious & not serious & not serious & none & $\begin{array}{l}\text { Case described of teen with BN } \\
\text { treated with fluoxetine } 20 \mathrm{mg} \text { who } \\
\text { developed mania - fluoxetine } \\
\text { stopped and valproate started. }\end{array}$ & $\begin{array}{l}\oplus \bigcirc \bigcirc \bigcirc \\
\text { VERY LOW }\end{array}$ & CRITICAL \\
\hline
\end{tabular}

\section{Explanations}

a no control group

Bibliography:

Case Series - Kotler 2003 [173]

Case report - Tor 2008 [174] 
Table 34 SSRIs for children and adolescents with OSFED/EDNOS

\begin{tabular}{|c|c|c|c|c|c|c|c|c|c|}
\hline \multicolumn{7}{|c|}{ Certainty assessment } & \multirow[t]{2}{*}{ Impact } & \multirow[t]{2}{*}{ Certainty } & \multirow[t]{2}{*}{ Importance } \\
\hline $\begin{array}{l}\text { № of } \\
\text { studies }\end{array}$ & $\begin{array}{l}\text { Study } \\
\text { design }\end{array}$ & $\begin{array}{l}\text { Risk of } \\
\text { bias }\end{array}$ & Inconsistency & Indirectness & Imprecision & $\begin{array}{l}\text { Other } \\
\text { considerations }\end{array}$ & & & \\
\hline \multicolumn{10}{|c|}{ Depressive symptoms (assessed with: clinical impression) } \\
\hline 1 & $\begin{array}{l}\text { Case } \\
\text { Report }\end{array}$ & $\begin{array}{l}\text { very } \\
\text { serious }{ }^{a}\end{array}$ & not serious & not serious & not serious & none & $\begin{array}{l}\text { Single case report of adolescent } \\
\text { female, initially overweight with } \\
\text { depressive symptoms. Treated with } \\
\text { escitalopram } 10 \mathrm{mg} \text { and depressive } \\
\text { symptoms improved. }\end{array}$ & $\begin{array}{l}\oplus \bigcirc \bigcirc \bigcirc \\
\text { VERY LOW }\end{array}$ & IMPORTANT \\
\hline
\end{tabular}

Explanations

${ }^{a}$ no control group, single case report

Bibliography:

Case Report - Wolter 2009 [175]

series of three children with "severe choking phobias" were successfully treated with low-dose SSRIs (sertraline and paroxetine) [176]. Spettigue and colleagues [53] also described the treatment of six children with ARFID treated with combinations of SSRIs and antipsychotics (described above in more detail in the olanzapine section).

\section{Other antidepressants - mirtazapine}

Anorexia nervosa To date, one case control study as well as two case reports involving the use of mirtazapine in AN have been published (Table 36). Hrdlicka and colleagues [179] examined nine adolescent patients with AN who had been treated with mirtazapine for anxiety or depression compared to nine female controls with AN. The two groups were matched in terms of age and BMI. The mean dose of mirtazapine was $21.7 \mathrm{mg}$ daily. There were no significant differences in terms of weight or BMI at the end of this study [179].

In terms of the case reports, the first case report described a 16 year old female hospitalized for AN and depression treated with mirtazapine [180]. These authors found positive results in terms of weight restoration and mood improvement, and suggested further study of the medication was needed. More recently, Naguy and Al-Mutairi [181] described the case of a 16 year old boy hospitalized for severe AN who responded well to mirtazapine $30 \mathrm{mg} /$ day in terms of weight restoration.

Avoidant/restrictive food intake disorder For ARFID, mirtazapine has also been used to good effect, although the evidence is limited to one case series and one case report (Table 37). The case series described 14 cases with the rate of weight gain reported pre and post initiation of mirtazapine (average dose $25.5 \mathrm{mg}$ daily) [182]. Rate of weight gain was significantly greater after the initiation of the medication. An additional case report described the treatment of a 10 year old girl with ARFID and Obsessive-Compulsive Disorder (OCD). Anxiety and eating improved with $15 \mathrm{mg}$ daily [183].

Lack of evidence No studies could be found on the use of Selective Norepinephrine Reuptake Inhibitors (SNRIs)

Table 35 SSRIs for children and adolescents with avoidant/restrictive food intake disorder

\begin{tabular}{|c|c|c|c|c|c|c|c|c|c|}
\hline \multicolumn{7}{|c|}{ Certainty assessment } & \multirow[t]{2}{*}{ Impact } & \multirow[t]{2}{*}{ Certainty } & \multirow[t]{2}{*}{ Importance } \\
\hline $\begin{array}{l}\text { № of } \\
\text { studies }\end{array}$ & $\begin{array}{l}\text { Study } \\
\text { design }\end{array}$ & $\begin{array}{l}\text { Risk of } \\
\text { bias }\end{array}$ & Inconsistency & Indirectness & Imprecision & $\begin{array}{l}\text { Other } \\
\text { considerations }\end{array}$ & & & \\
\hline \multicolumn{10}{|c|}{ Anxiety (assessed with: clinical impression) } \\
\hline 5 & $\begin{array}{l}\text { Case } \\
\text { Reports }\end{array}$ & $\begin{array}{l}\text { very } \\
\text { serious }^{a}\end{array}$ & not serious & not serious & not serious & none & $\begin{array}{l}13 \text { patients ( } 3 \text { male, } 10 \text { female) } \\
\text { treated with various SSRIs } \\
\text { including fluoxetine (8), } \\
\text { paroxetine (2), fluvoxamine (1), } \\
\text { sertraline (1), escitalopram (1). } \\
\text { All cases } \\
\text { experienced an improvement } \\
\text { in anxiety and improved eating. }\end{array}$ & $\begin{array}{l}\oplus \bigcirc \bigcirc \bigcirc \\
\text { VERY LOW }\end{array}$ & CRITICAL \\
\hline
\end{tabular}


Table 36 Mirtazapine for children and adolescents with Anorexia Nervosa

\begin{tabular}{|c|c|c|c|c|c|c|c|c|c|}
\hline \multicolumn{7}{|c|}{ Certainty assessment } & \multirow[t]{2}{*}{ Impact } & \multirow[t]{2}{*}{ Certainty } & \multirow[t]{2}{*}{ Importance } \\
\hline $\begin{array}{l}\text { № of } \\
\text { studies }\end{array}$ & $\begin{array}{l}\text { Study } \\
\text { design }\end{array}$ & $\begin{array}{l}\text { Risk of } \\
\text { bias }\end{array}$ & Inconsistency & Indirectness & Imprecision & $\begin{array}{l}\text { Other } \\
\text { considerations }\end{array}$ & & & \\
\hline \multicolumn{10}{|c|}{ Weight (assessed with: kg) } \\
\hline 1 & $\begin{array}{l}\text { Case } \\
\text { Control }\end{array}$ & serious $^{a}$ & not serious & not serious & not serious & none & $\begin{array}{l}9 \text { females with AN treated with } \\
\text { mirtazapine (mean dose } 21.7 \mathrm{mg} / \\
\text { day) matched with } 9 \text { controls. No } \\
\text { significant differences in weight or } \\
\text { BMl at the end of } 4 \text { weeks of } \\
\text { treatment. }\end{array}$ & $\begin{array}{l}\oplus \bigcirc \bigcirc \bigcirc \\
\text { VERY LOW }\end{array}$ & CRITICAL \\
\hline \multicolumn{10}{|c|}{ Weight (assessed with: kg) Depression (assessed with: clinical impression) } \\
\hline \multirow[t]{2}{*}{2} & $\begin{array}{l}\text { Case } \\
\text { Reports }\end{array}$ & $\begin{array}{l}\text { very } \\
\text { serious } a, b\end{array}$ & not serious & not serious & not serious & none & $\begin{array}{l}\text { Two case reports (one male, one } \\
\text { female) with AN and depression. } \\
\text { Both improved in weight. }\end{array}$ & $\begin{array}{l}\oplus \bigcirc \bigcirc \bigcirc \\
\text { VERY LOW }\end{array}$ & CRITICAL \\
\hline & & $\begin{array}{l}\text { very } \\
\text { serious }{ }^{a, b}\end{array}$ & not serious & not serious & not serious & none & $\begin{array}{l}\text { One of these case reports } \\
\text { mentioned remission of depression } \\
\text { in the context of AN with } \\
\text { treatment with mirtazapine }(30 \mathrm{mg}) \text {. }\end{array}$ & $\begin{array}{l}\oplus \bigcirc \bigcirc \bigcirc \\
\text { VERY LOW }\end{array}$ & CRITICAL \\
\hline
\end{tabular}

\section{Explanations}

${ }^{\text {a }}$ subjects were not randomized

bno control condition

Bibliography:

Case Control - Hrdlicka 2008 [179]

Case Report - Jaafar 2007 [180], Naguy 2018 [181]

for this population. The same was true for Mood Stabilizers.

\section{Level of care}

The database search initially provided 7136 citations, as reported in the PRISMA flow diagram (Fig. 5). An additional 49 citations were added through review of references, and forward citation chaining. After removing the duplicates, 6426 records remained, of which 5881 were eliminated on screening given that they did not meet the inclusion criteria. Of the 545 full text articles assessed for eligibility, 440 full text articles were excluded because they were longitudinal follow-up studies, primarily adult studies, review or secondary analysis papers, book chapters or guidelines, did not provide sufficient description of the treatment provided, did not focus on inpatient treatment or otherwise did not meet the inclusion criteria. Ultimately, 105 studies were selected for inclusion in the level of care section of this guideline -70 within the inpatient subsection, 29 within the day hospital subsection, and six within the residential subsection.

Table 37 Mirtazapine for children and adolescents with avoidant/restrictive food intake disorder

\begin{tabular}{|c|c|c|c|c|c|c|c|c|c|}
\hline \multicolumn{7}{|c|}{ Certainty assessment } & \multirow[t]{2}{*}{ Impact } & \multirow[t]{2}{*}{ Certainty } & \multirow[t]{2}{*}{ Importance } \\
\hline $\begin{array}{l}\text { № of } \\
\text { studies }\end{array}$ & $\begin{array}{l}\text { Study } \\
\text { design }\end{array}$ & $\begin{array}{l}\text { Risk of } \\
\text { bias }\end{array}$ & Inconsistency & Indirectness & Imprecision & $\begin{array}{l}\text { Other } \\
\text { considerations }\end{array}$ & & & \\
\hline \multicolumn{10}{|c|}{ Mealtime Anxiety (assessed with: clinical impression) } \\
\hline 1 & $\begin{array}{l}\text { Case } \\
\text { Series }\end{array}$ & $\begin{array}{l}\text { very } \\
\text { serious }^{a}\end{array}$ & not serious & not serious & not serious & none & $\begin{array}{l}\text { Retrospective chart review of } 14 \text { cases } \\
\text { pre and post documentation of rate } \\
\text { of weight gain pre and post } \\
\text { mirtazapine. Rate of gain significantly } \\
\text { greater after mirtazapine (mean dose } \\
25.5 \mathrm{mg} \text { ). }\end{array}$ & $\begin{array}{l}\oplus \bigcirc \bigcirc \bigcirc \\
\text { VERY LOW }\end{array}$ & CRITICAL \\
\hline \multicolumn{10}{|l|}{ Anxiety } \\
\hline 1 & $\begin{array}{l}\text { Case } \\
\text { Report }\end{array}$ & $\begin{array}{l}\text { very } \\
\text { serious }^{a}\end{array}$ & not serious & not serious & not serious & none & $\begin{array}{l}\text { Single case report of } 10 \text { yo girl with } \\
\text { ARFID and OCD treated with } 15 \text { mg/ } \\
\text { day of mirtazapine. Anxiety improved } \\
\text { and she began to eat solid food } \\
\text { within } 1-2 \text { weeks. }\end{array}$ & $\begin{array}{l}\oplus \bigcirc \bigcirc \bigcirc \\
V E R Y \text { LOW }\end{array}$ & CRITICAL \\
\hline
\end{tabular}

Explanations

ano control condition

Bibliography:

Case series - Gray 2018 [182]

Case Report - Tanidir 2015 [183] 


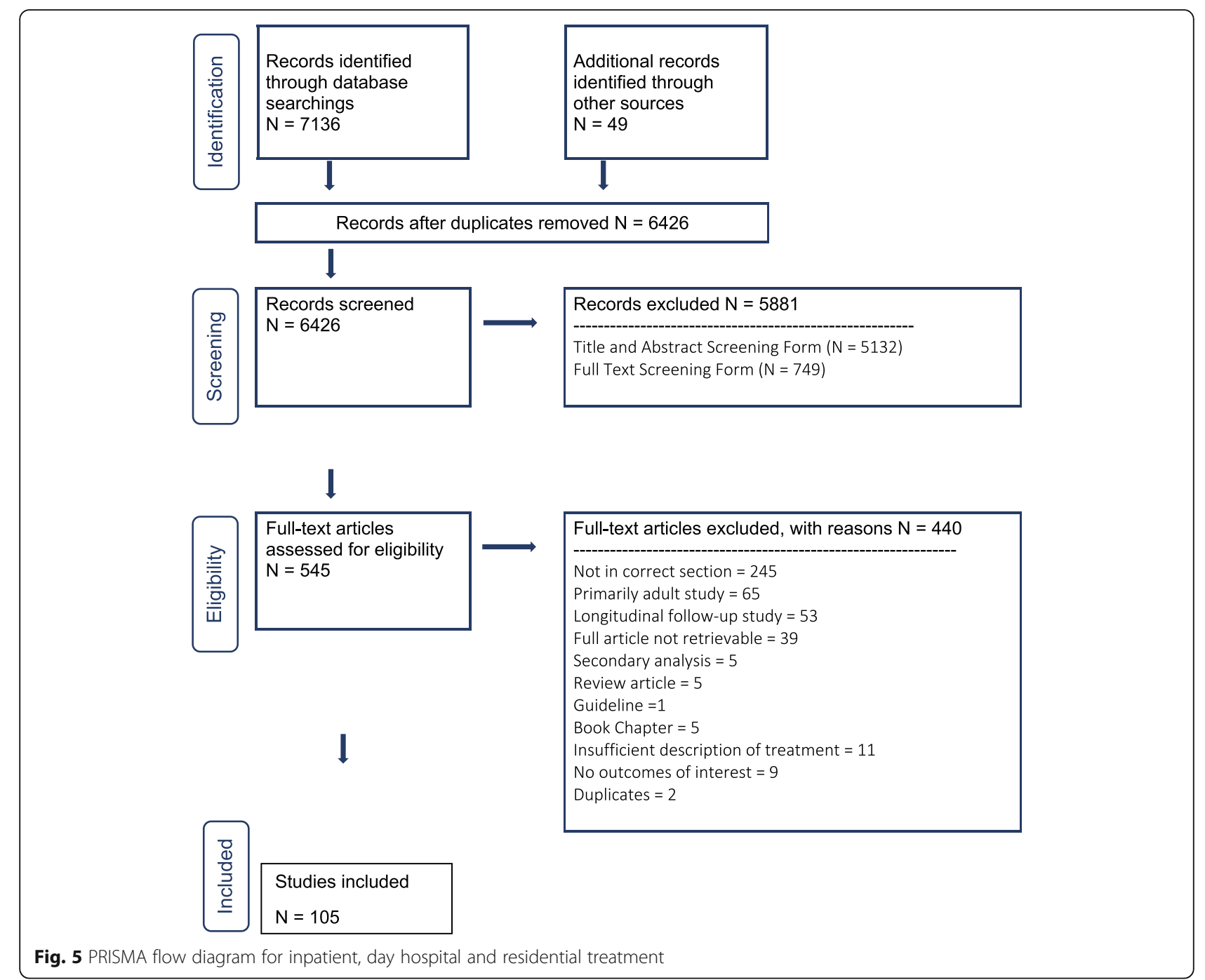

\section{Inpatient}

\section{Multimodal treatment}

Anorexia nervosa Twenty-one observational studies, none of which included control or comparison groups, have been published for a combined total of 1347 patients (Table 38) [184-191, 193-196, 198, 199, 201-207]. Various measures of change in weight were used across these studies including BMI, absolute weight in $\mathrm{kg}$, percent Treatment Goal Weight (\%TGW), weight gain per week and percent of patients attaining a predetermined discharge weight prior to discharge. Mean change in weight was positive in all studies. Mean length of stay ranged from 20.10 to 328.5 days.

While all of the observational studies of multimodal inpatient treatment reported on change in weight, fewer reported on change in eating disorder symptoms. Three studies (total $n=88$ ) reported on Eating Disorders Examination-Questionnaire (EDE-Q) and one of the three studies reported significant change $(n=44, p<$ $0.05)[187,201,207]$. This pre-post difference was attributed predominantly to the restraint and eating concerns subscales. Mean length of stay for these studies was between 203 and 115 days. Three studies (total $n=126$ ) reported improvements in Eating Attitudes Test (EAT) scores at admission and discharge [186, 198, 203]. Length of stay varied between these three studies (29.8 days, 91 days and not reported). One study (total $n=44$ ), with a mean LOS of 115 days reported on Eating Disorder Inventory (EDI) scores at admission and discharge [187]. This study found no significant change in total or subscales of the EDI. One study reported on frequency of binge, laxative and exercise symptoms, however the total number of patients reporting these symptoms at admission was small (i.e. laxatives 0, bingeing 3, exercise 5) [188]. Overall the study population was small (total $n=11$ at admission and 7 at discharge). No statistical change was noted in any of these outcomes. 
Table 38 Multimodal inpatient treatment for anorexia nervosa and/or low weight eating disorders

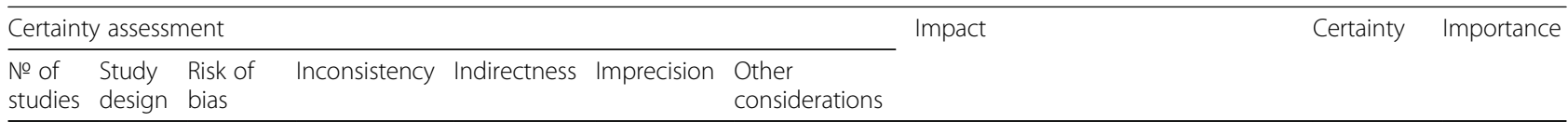

Weight (assessed with: Change in Weight Measures from Admission to Discharge), ED Symptoms (EDE-Q, EDI, EAT), motivational stage of change, laxative use, binge eating

Case very
Series serious ${ }^{a}$ very serious $^{\text {d }}$ not serious serious $^{c}$ all plausible

residual confounding would reduce the demonstrated effect
Twenty studies examined change in weight during inpatient treatment for total 1346 patients. Various measures of change in weight used across studies including BMI, absolute weight in KG, \%TGW, weight gain per week and $\%$ of patients attaining predetermined $\mathrm{D} / \mathrm{C}$ weight prior to $d / c$. Seventeen $(N=1319)$ used $\mathrm{BMI}$ as measure of weight. Mean $\mathrm{BMI}$ at admission varied from 13.2 to 16.3 between studies. Mean $\mathrm{BMl}$ at $\mathrm{d} / \mathrm{c}$ varied from 16.3 to 19.49. Change in BMl from admission to $\mathrm{d} / \mathrm{c}$ varied from 1.4 to 4.1. One study $(n=40)$ reported on mean $\mathrm{BMI} \%$ change which rose from BMI $8.98(+/-2.07)$ to 21.25 $(+/-3.13)$. Six studies $(n=134)$ reported mean absolute weight gain during admission which varied from 5.4 to $10.1 \mathrm{~kg}$. Three studies $(N=151)$ reported mean \%TGW change admission to discharge of 10.3 and $10.5 \%$. One study $(n=40)$ only reported weight outcomes as rate of weight gain per week which was $1.86 \mathrm{~kg} / \mathrm{wk}$. with a mean LOS of 20.63 days (SD 13.03). Finally 2 studies reported on the $\%$ of patients attaining a pre-determined adequate weight as inpatients with 1 study reporting $76.1 \%$ $(n=196)$ reaching a mean $\mathrm{BMI}$ of $>17.63$ and 1 study reporting 79.6\% $(n=108)$ attaining $>90 \%$ TGW at time of $d / c$. LOS varied considerably which is likely related to difference in weight change as an inpatient. Mean LOS ranged from 20.10 to 328.5 days between studies. One study noted that longer LOS, lower age at admission and no previous inpatient treatment was associated with greater improvement in BMI.

Three studies - Two self-report measures of symptoms were used (EDI-3 and EDE-Q), change reported from admission to discharge. Treatment provided was multimodal. Three studies (total $n=88$ ) reported on EDE-Q. Change in EDE-Q was found to be significant in one of these studies $(n=44, p<0.05)$ - this difference was attributed to the restraint and eating concerns subscales. In the other 2 studies there was no difference in EDE scores from admission to discharge. LOS for $\oplus \bigcirc \bigcirc \bigcirc$ CRITICAL VERY LOW $\oplus \bigcirc \bigcirc \bigcirc$ CRITICAL VERY LOW 
Table 38 Multimodal inpatient treatment for anorexia nervosa and/or low weight eating disorders (Continued)

\begin{tabular}{|c|c|c|c|c|c|c|}
\hline \multicolumn{7}{|c|}{ Certainty assessment } \\
\hline $\begin{array}{l}\text { № of } \\
\text { studies }\end{array}$ & $\begin{array}{l}\text { Study } \\
\text { design }\end{array}$ & $\begin{array}{l}\text { Risk of } \\
\text { bias }\end{array}$ & Inconsistency & Indirectness & Imprecision & $\begin{array}{l}\text { Other } \\
\text { considerations }\end{array}$ \\
\hline
\end{tabular}

$$
\text { Impact }
$$

these studies was a mean of 203 and 115 days. BMI at discharge was higher in the study which found significant change in EDE-Q (ie BMI 19.49 vs 18.5 and BMI\% 21.25 at discharge).

\begin{tabular}{|c|c|c|}
\hline $\begin{array}{l}\text { very } \\
\text { serious }\end{array}$ & not serious serious ${ }^{c}$ & $\begin{array}{l}\text { all plausible } \\
\text { residual } \\
\text { confounding } \\
\text { would reduce } \\
\text { the } \\
\text { demonstrated } \\
\text { effect }\end{array}$ \\
\hline
\end{tabular}

\begin{tabular}{|c|c|c|c|c|}
\hline $\begin{array}{l}\text { very } \\
\text { serious }\end{array}$ & serious $^{e}$ & not serious & serious $^{9}$ & $\begin{array}{l}\text { all plausible } \\
\text { residual } \\
\text { confounding } \\
\text { would reduce } \\
\text { the } \\
\text { demonstrated } \\
\text { effect }\end{array}$ \\
\hline
\end{tabular}

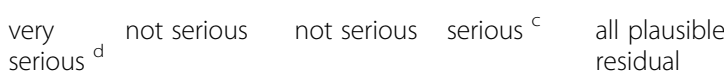
confounding would reduce the demonstrated effect

All three studies (total $n=126$ ) reported EAT scores at admission and discharge. Two studies used the EAT-26 and 1 study used the EAT-40. Treatment was multimodal and varied between studies. The difference in EAT score was noted to be statistically different in 2 studies $(p<0.001)$ and the third study reported a difference of 19 on the EAT-26 pre-post. LOS varied between studies (29.8 days, 91 days and not reported). Mean BMls at discharge in these 3 studies were 19.2. 18.4 and 16.3 .

One study - Number of patients reporting laxative use, binge/purge, exercise symptoms, even at admission were exceedingly small (ie laxatives 0 , bingeing 3 , exercise 5). Overall study small (total $n=11$ at admission and 7 at discharge). No statistical change noted in any of these outcomes.

One study with $n=49$ patients and mean LOS 30 days. Change in mean ANSOCQ was statistically significant, however both admission and $d / c$ scores fall into "preparation" phase of motivation and confidence intervals wide (ie admit score 53.6, SD 19.7 and d/c score 62.9, SD 24.5). During the course of the study BMI rose from 15.5 to 18.4 .

very
serious

strong association all plausible residual confounding would reduce the demonstrated effect
Three studies $(n=353)$, mean LOS 115 days, 33.61 and 81.9 days respectively, reported on EDI-2 outcomes. One study (LOS 115 days) found no significant change in total or subscales of EDl-2 from admission to discharge. One study ( $n=71$ and LOS 33.61 days) found statistically significant improvement on Drive for Thinness $(13.19+/-6.86$ at admission and $11.23+/-6.52$ at discharge, $p<0.05)$ and Bulimia $(1.50+/-2.15$ at admission and $0.66+/-1.08$ at discharge, $p<0.05$ ), but no change in Body Dissatisfaction. The final study ( $n=238)$ found statistically significant improvements in global (ES 0.8) and all subscales of the EDI-2. The largest effect size was found for Drive for Thinness $(E S=1.1)$ and the lowest for $\oplus \bigcirc \bigcirc \bigcirc \quad C R I T I C A L$ VERY LOW

$\oplus \bigcirc \bigcirc \bigcirc \quad$ IMPORTANT VERY LOW

$\oplus \bigcirc \bigcirc \bigcirc \quad$ IMPORTANT VERY LOW

$\oplus \bigcirc \bigcirc \bigcirc$ CRITICAL VERY LOW 
Table 38 Multimodal inpatient treatment for anorexia nervosa and/or low weight eating disorders (Continued)

\begin{tabular}{|c|c|c|c|c|c|c|c|c|c|}
\hline \multicolumn{7}{|c|}{ Certainty assessment } & \multirow[t]{2}{*}{ Impact } & \multirow[t]{2}{*}{ Certainty } & \multirow[t]{2}{*}{ Importance } \\
\hline $\begin{array}{l}\text { № of } \\
\text { studies }\end{array}$ & $\begin{array}{l}\text { Study } \\
\text { design }\end{array}$ & $\begin{array}{l}\text { Risk of } \\
\text { bias }\end{array}$ & Inconsistency & Indirectness & Imprecision & $\begin{array}{l}\text { Other } \\
\text { considerations }\end{array}$ & & & \\
\hline & & & & & & & "Maturity Fears" (ES = 0.3). & & \\
\hline \multicolumn{10}{|l|}{ Weight } \\
\hline 1 & $\begin{array}{l}\text { Case } \\
\text { Study }\end{array}$ & $\begin{array}{l}\text { very } \\
\text { serious }\end{array}$ & serious $^{\mathrm{e}}$ & not serious & serious $^{c}$ & $\begin{array}{l}\text { strong } \\
\text { association } \\
\text { all plausible } \\
\text { residual } \\
\text { confounding } \\
\text { would reduce } \\
\text { the } \\
\text { demonstrated } \\
\text { effect }\end{array}$ & $\begin{array}{l}\text { One case report describing a } \\
17.1 \mathrm{~kg} \text { wt gain }\end{array}$ & $\begin{array}{l}\oplus \bigcirc \bigcirc \bigcirc \\
\text { VERY LOW }\end{array}$ & CRITICAL \\
\hline
\end{tabular}

Explanations

abservational studies with no comparison group

${ }^{\mathrm{b}}$ Multimodal treatment not well described/defined

cConfidence interval wide and cross over threshold for change

${ }^{\mathrm{d}}$ Self-report measures and no control/comparison group

eDiffering inclusion/exclusion criteria and treatments provided

funclear how these symptoms were measured and study took place over two sites which may have resulted in variation

${ }^{9}$ Number of patients in study small and numbers reporting these particular symptoms even smaller

Case Series - Anis 2016 [184], Ayton 2009 [185], Castro-Fornieles 2007 [186], Fennig 2017 [187], Goddard 2013 [188], Heinberg 2003 [189], Kalisvaart 2007 [190],

Leon 1985 [191], Lievers 2009 [192], Mekori 2017 [193], Morris 2015 [194], Nova 2007 [195], Roux 2016 [196], Schlegl 2016 [197], Shugar 1995 [198], Tasaka 2017

[199], Treat 2008 [200], Vall 2017 [201], Bourion-Bedes 2013 [202], Rothschild-Yakar 2013 [203]

Case Reports - Toms 1972 [204]

Although not a focus of our guideline, one study measured motivation for change using the Anorexia Nervosa Stage of Change Questionnaire (ANSOCQ) at admission and then again at discharge [186]. The study included 49 patients whose mean length of stay was 30 days. Change in mean ANSOCQ score was noted to be statistically significant, however both admission and discharge scores fell into the "preparation" phase of motivation and the confidence intervals were wide.

Mixed diagnoses Two studies of multimodal inpatient treatment were found which reported on weight gain during inpatient treatment for patients with mixed eating disorder diagnoses (Table 39). One study differentiated between patients with AN restricting type versus those with AN binge-purge type or BN [203], and the other differentiated between those with AN restricting type or AN binge-purge type versus those with $\mathrm{BN}$ or Eating Disorder Not Otherwise Specified binge-purge type (EDNOS-B/P) [193]. Multimodal treatment was provided in both studies but varied between studies. Total number of patients studied was 150 across the two studies. In both cases there was a significantly greater increase in BMI for the group containing AN restricting type patients (total $n=94$ ). In both cases this group started with a much lower BMI. Length of stay in these studies was approximately 6-7 months.

One of these studies compared symptom change using the EAT at admission to discharge in the group of patients with AN restricting type $(n=33)$ versus AN binge-purge type or BN $(n=29)$ [203]. Overall there was a statistically significant improvement in EAT scores over the course of the admission. There was no significant difference in change on EAT by diagnosis.

Avoidant/restrictive food intake disorder Four articles were found which reported on the inpatient treatment of a total of thirteen children treated using either a family-based or cognitive behaviour therapy approach [53, 208-210] (Table 40). Length of stay for these studies varied from 16 days to 60 days. In two of these studies weight gain was reported as an outcome and all patients gained weight [53, 208]. One of these studies reported on caloric intake in $\mathrm{kcal} /$ day which rose for all three patients [208]. The third study reported on two cases of females ages 17 and 13 years who were "severely underweight" due to the onset of vomiting and food refusal [209]. After admission, nasojejunum (NJ) tubes were placed to initiate refeeding when oral feeding was not tolerated. The authors reported that the use of an individualized behaviour plan for each patient providing reinforcements for eating was the critical factor which helped these patients to tolerate oral intake without vomiting and allowed for the removal of the NJ tubes.

\section{Family-based inpatient care}

Anorexia nervosa There were three studies found examining inpatient treatment utilizing a family-based 
Table 39 Multimodal inpatient treatment for children and adolescents with eating disorders

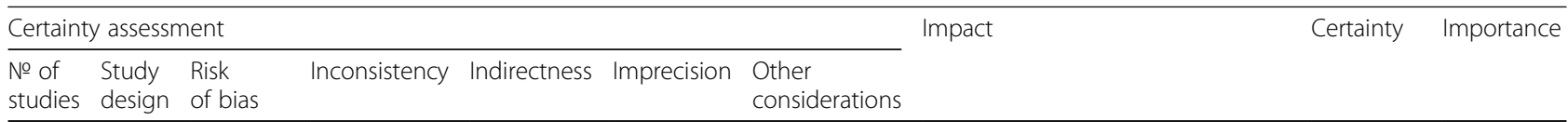

Change in Weight (assessed with: Change in BMl from Admit to D/C) $2 \quad$ Case very serious $^{b}$ not serious not serious none

$$
\begin{aligned}
& \text { very not serious not serious serious } \\
& \text { serious }^{\mathrm{a}, \mathrm{c}}
\end{aligned}
$$

Explanations

a Observational Study with no control/comparison

${ }^{b}$ Differing inclusion/exclusion criteria and treatments provided

'Self-report scale

${ }^{d}$ Wide confidence intervals which cross over threshold of change

Bibliography:

Case Series - Rothschild-Yakar 2013 [203], Mekori 2017 [193]

approach, one of which included 37 patients [211], and the other two studies which included one patient each (i.e. case reports) $[39,63]$ (Table 41 ). Length of stay in hospital was a mean of 20.6 weeks $(\mathrm{SD}=13.6$, range 358 ) in the first study [211] and 10 days in one case report [39] and unclear in the second case report [63]. Mean weight gain was reported as $7.5 \mathrm{~kg}$ in the case series [211], a change in BMI from 16.32 to 17.5 in one case report [39], and a change in BMI of 15.4 to 19.5 in the other case report [63]. In the case report by Goldfield and Boachie [63], the family received eight sessions of family-based informed therapy via telepsychiatry as one parent and siblings were not local.
One study differentiated between patients with AN-R vs those with $\mathrm{AN}-\mathrm{B} / \mathrm{P}$ or $\mathrm{BN}$ and the other differ entiated between those with $\mathrm{AN}-\mathrm{R}$ or $\mathrm{AN}-\mathrm{B} / \mathrm{P}$ and those with $\mathrm{BN}$ or EDNOS-B/P. Multimodal treatment was provided in both studies, but varied between studies. Total $n=$ 150 across the two studies. In both studies there was a significantly greater increase in BMl for the (total $n=94$ ). In both studies this group started with a much lower BMI (ie 14.94 and 15.78) and d/c BMI was 19.24 and 19.79. In the group containing only $\mathrm{BN}$ and EDNOS-B/P $(n=27)$ there was no change in BMl during admission. LOS in these studies was 6.25 $+/-2.28$ months and $6.8+/-3$ months.

all plausible Study compared EAT-26 at residual confounding would reduce the demonstrated effect admission to discharge in group of patients with $\mathrm{AN}-\mathrm{R}(n=33)$ vs was a statistically significant improvement in EAT-26 over the course of the admission $(p<0.001)$. group containing AN-R patients

\section{$\oplus \bigcirc \bigcirc \bigcirc$ CRITICAL} VERY LOW $\mathrm{AN}-\mathrm{B} / \mathrm{P}$ or $\mathrm{BN}(n=29)$. Overall there In AN-R groups EAT-26 score decreased from 41.8 (SD 18.56) to 32.17 (SD 22.2) and in AN-B/P or BN group EAT-26 score decreased from 46.67 (SD 15) to 28.83 (SD 14.74). There was no significant difference in change on EAT-26 by diagnosis. LOS was $6.25+/-2.28$ months. $\oplus \bigcirc \bigcirc \bigcirc$
VERY LOW IMPORTANT 
Table $\mathbf{4 0}$ Inpatient Treatment for ARFID

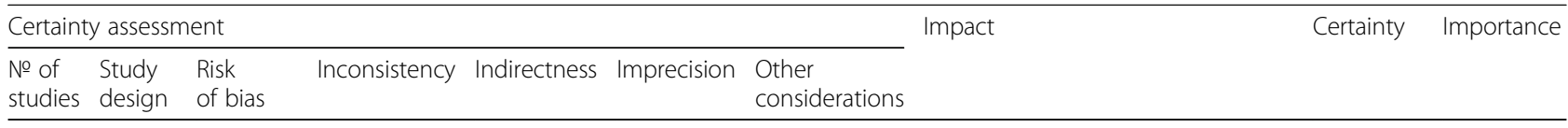

Weight Change (assessed with: Pre-post weight in KG), caloric intake, ability to tolerate oral intake Case very not serious not serious not serious none
Reports serious very not serious not serious not serious none

very serious $^{b}$ not serious not serious serious ${ }^{c}$ none
Two articles reporting on case studies of 3 boys with ARFID ages 6-8 yrs. treated in an inpatient CBTbased treatment program and 2 studies reporting on a total of 5 children ages 9-13 yrs. treated in a family-based inpatient setting. LOS varied from 16 days to 112 days. All patients gained weight. For studies reporting on absolute weight gain the cases gained $2.7 \mathrm{~kg}$ in 60 days, $1.2 \mathrm{~kg}$ in 16 days and $0.3 \mathrm{~kg}$ in 19 days). At discharge these patients were at 97, 104 and 96\%TGW. For the study reporting on change in $\%$ TGW, patients weight improved from 83 to $100 \%$ TGW (in $38 \mathrm{~d}$ ), 75.8 to $100 \%$ TGW (in 2 months) and 72 to $88 \%$ TGW (in 2 months) and 69 to $86.8 \%$ TGW (LOS unclear)

One study reporting on 3 case studies on boys with ARFID ages 6-8 years treated in an inpatient CBT-based program. LOS varied from 16 to 60 days. Caloric intake in $\mathrm{kcal} /$ day rose for all 3 patients (from 1557 to 2208,740 to 1300 , and 1200 to 1500 ).

One study reporting on 2 cases of females ages 17 and 13 yrs. and one study describing two 9 yo girls. In the adolescent case reports both patients were severely underweight and due to the onset of vomiting and food refusal after admission NJ tubes were placed. Authors report that the use of an individualized behaviour plan for each patient providing reinforcements for eating was the critical factor in helping patients to tolerate oral intake without vomiting. The case reports involving the 9 yo girls, in both cases the patients were exclusively NGT fed due to a refusal of all oral nutrition, but with the addition of family therapy and mobilization from hospital the patients were able to resume eating orally. $\oplus \bigcirc \bigcirc \bigcirc \quad$ CRITICAL VERY LOW

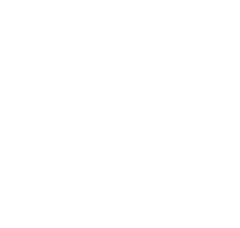

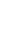


Table 41 Family-based inpatient treatment for children and adolescents with anorexia nervosa

\begin{tabular}{|c|c|c|c|c|c|c|c|c|c|}
\hline \multicolumn{7}{|c|}{ Certainty assessment } & \multirow[t]{2}{*}{ Impact } & \multirow[t]{2}{*}{ Certainty } & \multirow[t]{2}{*}{ Importance } \\
\hline $\begin{array}{l}\text { № of } \\
\text { studies }\end{array}$ & $\begin{array}{l}\text { Study } \\
\text { design }\end{array}$ & $\begin{array}{l}\text { Risk } \\
\text { of bias }\end{array}$ & Inconsistency & Indirectness & Imprecision & $\begin{array}{l}\text { Other } \\
\text { considerations }\end{array}$ & & & \\
\hline \multicolumn{10}{|c|}{ Change in weight (assessed with: Absolute weight gain during admission in kg) } \\
\hline 1 & $\begin{array}{l}\text { Case } \\
\text { Series }\end{array}$ & $\begin{array}{l}\text { very } \\
\text { serious }\end{array}$ & not serious & not serious & not serious & none & $\begin{array}{l}\text { One case series including } 37 \text { patients. } \\
\text { LOS in hospital was a mean of } \\
20.6 \text { weeks ( } S D=13.6 \text {, range } 3-58 \text { ) in } \\
\text { this study. Weight gain was reported } \\
\text { as } 7.5 \mathrm{~kg} \text { (SD } 4.4 \text {, range }-1.1 \text { to } 14.8 \mathrm{~kg} \text { ) }\end{array}$ & $\begin{array}{l}\oplus \bigcirc \bigcirc \bigcirc \\
\text { VERY LOW }\end{array}$ & CRITICAL \\
\hline \multicolumn{10}{|l|}{ Weight } \\
\hline 2 & $\begin{array}{l}\text { Case } \\
\text { Reports }\end{array}$ & $\begin{array}{l}\text { very } \\
\text { serious }^{a}\end{array}$ & not serious & not serious & not serious & none & $\begin{array}{l}\text { Two case reports - LOS in hospital } \\
\text { was } 10 \text { days in one case report and } \\
\text { unclear in the second case report. A } \\
\text { change in BMI from } 16.32 \text { to } 17.5 \\
\text { (ie } 82 \% \text { TGW to } 85.8 \% \text { TGW) in one } \\
\text { case report, and a change in BMl of } \\
15.4 \text { to } 19.5 \text { in the second case report. } \\
\text { In the second case report the family } \\
\text { received } 8 \text { sessions of family-based } \\
\text { informed therapy via telepsychiatry as } \\
\text { one parent and siblings were not local. }\end{array}$ & $\begin{array}{l}\oplus \bigcirc \bigcirc \bigcirc \\
\text { VERY LOW }\end{array}$ & CRITICAL \\
\hline
\end{tabular}

Explanations

a Observational study with no comparison or control

Bibliography:

Case Series - Halvorsen 2018 [211]

Case Reports - Goldfield 2003 [63], Matthews 2016 [39]

Global Scores, $23.6 \%$ showed "reliable" changes, $28 \%$ of patients remained "unchanged" and 3.7\% "deteriorated".

\section{Behaviour therapy based inpatient care}

Anorexia nervosa Fifteen studies reported on inpatient treatment utilizing a behaviour therapy approach (4 case series and 11 case reports ) [214-228] (Table 43). These studies included a total of 219 patients. Length of stay in these studies ranged from 13 days to 6.25 weeks $[215,217,218]$. In all studies patients gained weight.

Two of the case reports described change in intake as measured by kcal/day from admission to discharge. Only one of these studies reported the length of stay, which was 39 days. Calorie intake increased from $1600 \mathrm{kcal} / \mathrm{d}$ at admission to $3900 \mathrm{kcal} / \mathrm{d}$ at discharge in this study [214]. The other study did not report the length of stay, but stated that intake increased from $850 \mathrm{kcal} / \mathrm{d}$ at admission to $1700 \mathrm{kcal} / \mathrm{d}$ at discharge [221].

Several studies reported on symptom change during admission to hospital. One case report described a decrease in purging after meals from $48 \%$ of meals/week to $0 \%$ of meals per week, although the length of stay for this patient was not noted [221]. Two studies reported on EAT scores over the course of inpatient treatment. One was a case report describing that EAT scores remained high for the first 7 weeks of treatment and then dropped (from total score of 60 to 10) over the last 3 weeks of a 10-week admission [225]. The other study measured EAT scores in 24 patients at admission and discharge (mean length of stay 11 weeks) and reported a change from total mean EAT of 37.1 at admission to 12.7 at discharge $(p=0.0001)$ [224].

Bulimia nervosa Only one case series of 24 patients was found that examined inpatient treatment specifically for $\mathrm{BN}$, and the treatment provided was based on behaviour therapy [229] (Table 44). The only eating disorder related outcome that was reported was weight. The mean LOS was 9.9 wks. (+/- 3.5 wks.). Weight decreased slightly over admission from a mean BMI of 20.6 to 20.5.

\section{Psychodynamic based inpatient care}

Anorexia nervosa Only two reports of a total of six patients being treated as inpatients using a psychodynamic based approach were found [230, 231] (Table 45). The length of stay for these patients varied between 1.5 months and 5 months. Patients were reported to have gained between $1.3 \mathrm{~kg} / \mathrm{month}$ to $6 \mathrm{~kg} / \mathrm{month}$ while admitted.

\section{Admission to pediatric unit}

Mixed diagnoses Four studies including a total of 200 patients, examined the effect of admission to a pediatric unit in terms of weight change in hospital [232-235] (Table 46). These studies did not include comparator groups and included patients with AN, BN and EDNOS. Mean length of stay varied between studies from 31 days to 85 days. In all studies weight improved. 
Table 42 CBT-based inpatient treatment for children and adolescents with anorexia nervosa

\begin{tabular}{|c|c|c|c|c|c|c|c|c|c|}
\hline \multicolumn{7}{|c|}{ Certainty assessment } & \multirow[t]{2}{*}{ Impact } & \multirow[t]{2}{*}{ Certainty } & \multirow[t]{2}{*}{ Importance } \\
\hline $\begin{array}{l}\text { № of } \\
\text { studies }\end{array}$ & $\begin{array}{l}\text { Study } \\
\text { design }\end{array}$ & $\begin{array}{l}\text { Risk of } \\
\text { bias }\end{array}$ & Inconsistency & Indirectness & Imprecision & $\begin{array}{l}\text { Other } \\
\text { considerations }\end{array}$ & & & \\
\hline \multicolumn{10}{|c|}{ Weight Change (assessed with: Pre-post weight measures), EDI-2 Scores pre and post } \\
\hline \multirow[t]{2}{*}{2} & \multirow[t]{2}{*}{$\begin{array}{l}\text { Case } \\
\text { Series }\end{array}$} & $\begin{array}{l}\text { very } \\
\text { serious }^{\text {a }}\end{array}$ & not serious & not serious & serious $^{b}$ & none & $\begin{array}{l}\text { Two studies - Total } 295 \text { patients. } \\
\text { In all studies patients gained } \\
\text { weight in hospital. Weight change } \\
\text { reported differently across studies. } \\
\text { One study reported BMl pre/post } \\
\text { with BMI increasing from } 14.83 \\
(+/-1.22) \text { at admission to } 17.34 \\
(+/-1.37) \text { at discharge signifying } \\
\text { an ES of } 2.1 \text {. One study reported } \\
\text { change in BMl \% which rose from } \\
\text { mean of } 1.46(+/-2.41) \text { at } \\
\text { admission to } 9.44(+/-6.68) \text { at } \\
\text { discharge. }\end{array}$ & $\begin{array}{l}\oplus \bigcirc \bigcirc \bigcirc \\
\text { VERY LOW }\end{array}$ & CRITICAL \\
\hline & & $\begin{array}{l}\text { very } \\
\text { serious }\end{array}$ & not serious & not serious & serious $^{b}$ & $\begin{array}{l}\text { all plausible } \\
\text { residual } \\
\text { confounding } \\
\text { would reduce } \\
\text { the } \\
\text { demonstrated } \\
\text { effect }\end{array}$ & $\begin{array}{l}\text { One study which included } 238 \\
\text { patients, mean LOS } 81.9(+/-31.9) \\
\text { days. Global score and all subscales } \\
\text { of the EDI-2 showed significant } \\
\text { improvements. The ES of the Global } \\
\text { score was } 0.8 \text {. For subscales the } \\
\text { highest ES was found for Drive for } \\
\text { Thinness with an ES of 1.1, and the } \\
\text { lowest ES was for Maturity Fears with } \\
\text { an ES of } 0.3 \text {. Forty-five \% showed } \\
\text { "clinically significant" changes in } \\
\text { EDI-2 Global Scores, } 23.6 \% \text { showed } \\
\text { "reliable" changes, } 28 \% \text { of patients } \\
\text { remained unchanged and } 3.7 \% \\
\text { deteriorated. }\end{array}$ & $\begin{array}{l}\oplus \bigcirc \bigcirc \bigcirc \\
\text { VERY LOW }\end{array}$ & IMPORTANT \\
\hline \multicolumn{10}{|l|}{ Weight } \\
\hline 1 & $\begin{array}{l}\text { Case } \\
\text { Report }\end{array}$ & $\begin{array}{l}\text { very } \\
\text { serious }\end{array}$ & not serious & not serious & serious $^{b}$ & none & $\begin{array}{l}\text { In the case study weight increased } \\
1.1 \mathrm{~kg} \text { in } 6 \text { days. }\end{array}$ & $\begin{array}{l}\oplus \bigcirc \bigcirc \bigcirc \\
\text { VERY LOW }\end{array}$ & CRITICAL \\
\hline
\end{tabular}

Explanations

${ }^{a}$ Observational study, no comparison/control

${ }^{b}$ Confidence intervals wide in some studies and overlapping with any true effect Bibliography:

Case Series - Salbach-Andrae 2009 [213], Schlegl 2016 [197]

Case Report - Paul 2013 [212]

\section{Inpatient adjunctive treatments}

\section{Adjunctive multi-family/parent group therapy}

Mixed diagnoses One study with total 112 patients with various eating disorder diagnoses reported on symptom change as measured by the EDI during admission to a multimodal inpatient eating disorders unit in two groups of patients; those who received adjunctive multi-family group therapy (MFT, $n=62$ ) and those who received adjunctive multi-parent group therapy (MPT, $n=50$ ) [236] (Table 47). Both MPT and MFT interventions "promoted an autonomy-supportive parental attitude and the adolescents' autonomy and self-determination." Parents were encouraged to "create the conditions supporting their daughters' autonomy in establishing healthy eating at home to indirectly increase their daughters' motivation". Affected children were only included in the MFT group. Group format was one introductory 3-h session followed by five 2-h sessions every 2 weeks. Measures were taken pre/post of the intervention. Patients were not randomized, but rather were allocated to MFT versus MPT depending on the time of admission. Results reported a main effect of time on drive for thinness $(p<0.001)$ and body dissatisfaction $(p<$ 0.001 ) as measured by EDI. Both scales improved independent of type of intervention. A separate case series of 32 inpatient adolescents ( 29 with $\mathrm{AN}, 3$ with $\mathrm{BN}$ ) described improvements in EDI score pre-post delivery of FamilyOriented Group Therapy [237].

\section{Meal support}

Mixed diagnoses Three studies were found that examined the effect of meal support/supervision as part of inpatient treatment for groups of patients with mixed eating disorders diagnoses [238-240] (Table 48). There were no significant differences between cohorts who 
Table 43 Behaviour therapy based inpatient treatment for children and adolescents with anorexia nervosa

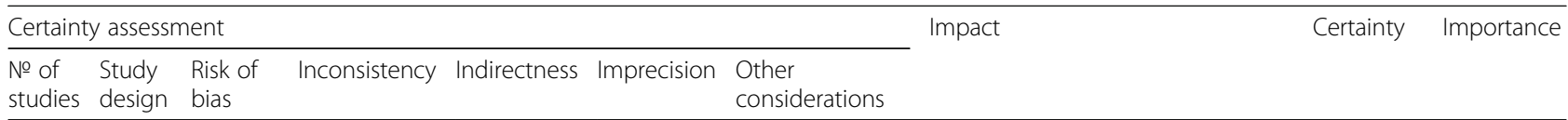

Change in Weight (assessed with: Pre-post measures of weight), Change in EAT scores, EDI Scores $4 \quad \begin{array}{ll}\text { Case very not serious not serious serious } \\ \text { Series } \\ { }^{b} \text { serious }\end{array}$
Four Case series utilizing a behaviour therapy approach. Total 198 patients. Various approaches to reporting change in weight. One study reported absolute weight change of $1.89 \mathrm{~kg} \mathrm{(+/-}$ 1.41) over a mean of 23 days in hospital; one study reported a rise from a mean of $65.9 \% \mathrm{TGW}$ to 87.4\%TGW over 11 weeks. One study reported that patients admitted at $>75 \%$ TGW all reached $100 \%$ of their TGW by discharge, $91 \%$ of those admitted at $<$ 75\%TGW not requiring NGT feeds reached their TGW by discharge and only $62 \%$ of patients admitted at $<75 \%$ TGW and requiring NGT feeds reached $100 \%$ of their TGW at discharge. This study also noted that those admitted at $>75 \%$ TGW had a mean LOS of $20.8 \mathrm{~d}$, those < 75\% TGW at admission had a mean LOS of $18.4 \mathrm{~d}$ and those < 75\%TGW and NGT fed had a mean LOS of 32.7d. The final case series reported weight gain under 2 types of behaviour contracts, varying only with regards to the expected rate of weight gain (ie $0.36 \mathrm{~kg} / \mathrm{q} 4 \mathrm{~d}$ vs $0.55 \mathrm{~kg} / \mathrm{q} 4 \mathrm{~d})$. Those treated under the contract requiring greater weight restoration gained weight at a faster rate $(0.09 \mathrm{~kg} / \mathrm{d}$, range $0.04-$ $0.4 \mathrm{~kg} / \mathrm{d}$ vs $0.17 \mathrm{~kg} / \mathrm{d}$, range $0.01-$ $0.64 \mathrm{~kg} / \mathrm{d}$ ), thereby attaining a greater weight gain overall during admission (LOS 28 days). Most case series reported weight gain observed while patients were adhering to a behaviour contract. LOS in these studies ranged from 13 days to 6.25 weeks. In all cases patients gained weight (ranging from 0.17 to $0.63 \mathrm{~kg} / \mathrm{day}$.

$\operatorname{very}_{\text {serious }}{ }^{a}$ not serious not serious serious ${ }^{c}$

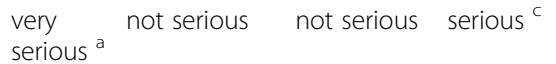

all plausible residual confounding would reduce the

demonstrated effect

One study measured EAT scores in 24 patients at admission and discharge (mean LOS 11 weeks) and reported a change from total mean EAT of 37.1 at admission to 12.7 at discharge $(p=0.0001)$.

all plausible residual confounding would reduce the

demonstrated effect $\oplus \bigcirc \bigcirc \bigcirc$ CRITICAL VERY LOW

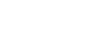


Table 43 Behaviour therapy based inpatient treatment for children and adolescents with anorexia nervosa (Continued)

\begin{tabular}{|c|c|c|c|c|c|c|c|c|c|}
\hline \multicolumn{7}{|c|}{ Certainty assessment } & \multirow[t]{2}{*}{ Impact } & \multirow[t]{2}{*}{ Certainty } & \multirow[t]{2}{*}{ Importance } \\
\hline $\begin{array}{l}\text { № of } \\
\text { studies }\end{array}$ & $\begin{array}{l}\text { Study } \\
\text { design }\end{array}$ & $\begin{array}{l}\text { Risk of } \\
\text { bias }\end{array}$ & Inconsistency & Indirectness & Imprecision & $\begin{array}{l}\text { Other } \\
\text { considerations }\end{array}$ & & & \\
\hline \multicolumn{10}{|c|}{ Change in Weight, Change in EAT score, change in intake, change in rate of purging } \\
\hline \multirow[t]{4}{*}{11} & $\begin{array}{l}\text { Case } \\
\text { reports }\end{array}$ & $\begin{array}{l}\text { very } \\
\text { serious }^{a}\end{array}$ & not serious & not serious & serious $^{b}$ & none & $\begin{array}{l}\text { Case reports all described patients } \\
\text { gaining weight in hospital ranging } \\
\text { from } 0.45 \mathrm{~kg} / \mathrm{wk} \text {. to } 4.0 \mathrm{~kg} / \mathrm{wk} \text {. Two } \\
\text { case reports did not note the LOS } \\
\text { andstated that the patients gained } \\
10 \mathrm{~kg} \text { total and change in BMl } \\
\text { from } 13.5 \text { to } 16.5 \text { during their } \\
\text { admissions. }\end{array}$ & $\begin{array}{l}\oplus \bigcirc \bigcirc \bigcirc \\
\text { VERY LOW }\end{array}$ & CRITICAL \\
\hline & & $\begin{array}{l}\text { very } \\
\text { serious }^{a}\end{array}$ & not serious & not serious & serious $^{c}$ & $\begin{array}{l}\text { all plausible } \\
\text { residual } \\
\text { confounding } \\
\text { would reduce } \\
\text { the } \\
\text { demonstrated } \\
\text { effect }\end{array}$ & $\begin{array}{l}\text { One case report describing that } \\
\text { EAT scores remained high for the } \\
\text { first } 7 \text { weeks of treatment and } \\
\text { weight restoration ( } 4.5 \mathrm{~kg} \text { over first } \\
7 \text { weeks) and then dropped (from } \\
\text { total score of } 60 \text { to 10) over the } \\
\text { last } 3 \text { weeks of } 10 \text { week admission. }\end{array}$ & $\begin{array}{l}\oplus \bigcirc \bigcirc \bigcirc \\
\text { VERY LOW }\end{array}$ & IMPORTANT \\
\hline & & $\begin{array}{l}\text { very } \\
\text { serious a }\end{array}$ & not serious & not serious & not serious & $\begin{array}{l}\text { strong } \\
\text { association }\end{array}$ & $\begin{array}{l}\text { Two case reports describing } \\
\text { change in intake measured by } \\
\mathrm{kcal} / \text { day from admission to } \\
\text { discharge. Only one study } \\
\text { reported LOS of } 39 \text { days. Kcal/day } \\
\text { increased from } 1600 \mathrm{kcal} / \mathrm{d} \text { at } \\
\text { admission to } 3900 \mathrm{kcal} / \mathrm{d} \text { at } \\
\text { discharge in this study. The other } \\
\text { study did not report on LOS, but } \\
\text { stated that intake increased from } \\
850 \mathrm{kcal} / \mathrm{d} \text { at admission to } 1700 \\
\mathrm{kcal} / \mathrm{d} \text { at discharge. }\end{array}$ & $\begin{array}{l}\oplus \bigcirc \bigcirc \bigcirc \\
\text { VERY LOW }\end{array}$ & CRITICAL \\
\hline & & $\begin{array}{l}\text { very } \\
\text { serious a }\end{array}$ & not serious & not serious & not serious & none & $\begin{array}{l}1 \text { case report describing a } \\
\text { decrease in purging after meals } \\
\text { from } 48 \% \text { of meals/week to } 0 \% \text { of } \\
\text { meals per week. LOS not noted. }\end{array}$ & $\begin{array}{l}\oplus \bigcirc \bigcirc \bigcirc \\
\text { VERY LOW }\end{array}$ & IMPORTANT \\
\hline
\end{tabular}

\section{Explanations}

${ }^{a}$ Observational studies with no comparison group or control

${ }^{b}$ Wide confidence intervals in some studies, overlapping with any true effect

${ }^{c}$ Confidence intervals not noted

Bibliography:

Case series - Collins 1983 [222], Solanto 1994 [227], Steinhausen 1985 [224], Nygaard 1990 [226]

Case reports - Alessi 1989 [225], Blanchet-Collet 2016 [228], Blinder 1970 [215], Boey 1985 [223], Cinciripini 1983 [221], Clark 1981 [220], Garfinkel 1973 [216],

Halmi 1975 [217], Leitenberg 1968 [214], Pertschuk 1978 [218], Poole 1978 [219]

Table 44 Behaviour therapy based inpatient treatment for children and adolescents with bulimia nervosa

\begin{tabular}{|c|c|c|c|c|c|c|c|c|c|}
\hline \multicolumn{7}{|c|}{ Certainty assessment } & \multirow[t]{2}{*}{ Impact } & \multirow[t]{2}{*}{ Certainty } & \multirow[t]{2}{*}{ Importance } \\
\hline $\begin{array}{l}\text { № of } \\
\text { studies }\end{array}$ & $\begin{array}{l}\text { Study } \\
\text { design }\end{array}$ & $\begin{array}{l}\text { Risk of } \\
\text { bias }\end{array}$ & Inconsistency & Indirectness & Imprecision & $\begin{array}{l}\text { Other } \\
\text { considerations }\end{array}$ & & & \\
\hline \multicolumn{10}{|c|}{ Change in weight (assessed with: Pre/post BMI) } \\
\hline 1 & $\begin{array}{l}\text { Case } \\
\text { Series }\end{array}$ & $\begin{array}{l}\text { very } \\
\text { serious a }\end{array}$ & not serious & not serious & not serious & none & $\begin{array}{l}\text { One case series, including } 24 \text { patients. } \\
\text { Mean LOS was } 9.9 \text { wks }(+/-3.5 \text { wks). } \\
\text { Weight decreased slightly over } \\
\text { admission from mean BMl of } 20.6 \\
+/-4.3 \text { to } 20.5+/-2.7 \text {. }\end{array}$ & $\begin{array}{l}\oplus \bigcirc \bigcirc \bigcirc \\
\text { VERY LOW }\end{array}$ & IMPORTANT \\
\hline
\end{tabular}


Table 45 Psychodynamic based inpatient treatment for children and adolescents with anorexia nervosa

\begin{tabular}{|c|c|c|c|c|c|c|c|c|c|}
\hline \multicolumn{7}{|c|}{ Certainty assessment } & \multirow[t]{2}{*}{ Impact } & \multirow[t]{2}{*}{ Certainty } & \multirow[t]{2}{*}{ Importanc } \\
\hline $\begin{array}{l}\text { № of } \\
\text { studies }\end{array}$ & $\begin{array}{l}\text { Study } \\
\text { design }\end{array}$ & $\begin{array}{l}\text { Risk of } \\
\text { bias }\end{array}$ & Inconsistency & Indirectness & Imprecision & $\begin{array}{l}\text { Other } \\
\text { considerations }\end{array}$ & & & \\
\hline \multicolumn{10}{|c|}{ Change in weight (assessed with: Pre/post measures of weight) } \\
\hline 2 & $\begin{array}{l}\text { Case } \\
\text { Reports }\end{array}$ & $\begin{array}{l}\text { very } \\
\text { serious }^{\text {a }}\end{array}$ & serious $^{b}$ & not serious & not serious & none & $\begin{array}{l}\text { Two reports of } 6 \text { patients total. LOS } \\
\text { varied between } 1.5 \text { months and } 5 \\
\text { months. Patients were reported to } \\
\text { have gained between } 1.3 \mathrm{~kg} / \mathrm{month} \\
\text { to } 6 \mathrm{~kg} / \mathrm{month} \text { while admitted. }\end{array}$ & $\begin{array}{l}\oplus \bigcirc \bigcirc \bigcirc \\
\text { VERY LOW }\end{array}$ & CRITICAL \\
\hline
\end{tabular}

Explanations

${ }^{\text {a }}$ Case reports only, no comparison/control

${ }^{\mathrm{b}}$ Large variation in results, likely due to individual factors of patients described in studies

Bibliography:

Case Reports - Kronenberg 1994 [231], Groen 1966 [230]

received meal support and those who did not on the rate of weight gain per day or week, although there was a trend towards greater weight gain in the group who received meal support. One of these studies reported on the difference in the rate of nasogastric tube (NGT) feeds in the cohort of patients treated on inpatient unit before the institution of consistent meal support versus after [238]. Eight of 12 patients not receiving meal support (66.7\%) and 1 of 9 (11.1\%) of those receiving meal support required NGT feeds as part of inpatient admission, which was a statistically significant difference.

\section{Selective versus non-selective menus}

Anorexia nervosa One study was found which included 22 patients with AN who received non-selective menus compared to 18 patients who received selective menus as part of their multimodal inpatient treatment [241] (Table 49). Length of stay varied between groups (although nonsignificantly) with patients on non-select menus remaining in hospital a mean of $60.3(+/-22.8)$ days vs $74.2(+/-28.7)$ days in the selective menus group. The non-selective menu group gained a significantly greater amount of weight. No significant differences were found on the EDE.

Table 46 Inpatient admission on pediatric unit for children and adolescents with eating disorders

\begin{tabular}{|c|c|c|c|c|c|c|c|c|c|}
\hline \multicolumn{7}{|c|}{ Certainty assessment } & \multirow[t]{2}{*}{ Impact } & \multirow[t]{2}{*}{ Certainty } & \multirow[t]{2}{*}{ Importance } \\
\hline $\begin{array}{l}\text { № of } \\
\text { studies }\end{array}$ & $\begin{array}{l}\text { Study } \\
\text { design }\end{array}$ & $\begin{array}{l}\text { Risk of } \\
\text { bias }\end{array}$ & Inconsistency & Indirectness & Imprecision & $\begin{array}{l}\text { Other } \\
\text { considerations }\end{array}$ & & & \\
\hline \multicolumn{10}{|c|}{ Weight Change (assessed with: Pre-post weight measures) } \\
\hline 3 & $\begin{array}{l}\text { Case } \\
\text { Series }\end{array}$ & $\begin{array}{l}\text { very } \\
\text { serious }^{a}\end{array}$ & not serious & not serious & not serious & none & $\begin{array}{l}\text { Three case series including a total of } \\
195 \text { patients. Mean LOS varied } \\
\text { between studies from } 31 \text { days to } 85 \\
\text { days. Two studies reported change in } \\
\text { weight using \%TGW. In both studies } \\
\text { weight rose during admission from } \\
\text { mean \%TGW of } 68 \%(+/-5.5) \text { to } 99 \% \\
(+/-7.7) \text {; mean \%TGW } 75.8 \%(+/-2.3) \\
\text { to } 85.4 \%(+/-1.7) \text { and } 73.7 \% \text { (+/- } 2.5) \\
\text { to } 86.4 \% \text { (+/- } 3.0 \mathrm{~kg} \text { ) (note: results } \\
\text { reported in two groups in second } \\
\text { study based on whether the patients } \\
\text { were followed after discharge).. The } \\
\text { final study including } 102 \text { children aged } \\
8-12 \text { yrs. with diagnoses of restrictive } \\
\text { ED (93.1\%) or bulimia (7.1\%). At } \\
\text { admission the mean weight was } 32.3 \\
\text { kg (SD 7.7) and at discharge mean } \\
\text { weight was } 35.4 \mathrm{~kg} \text { (SD 8.9). }\end{array}$ & $\begin{array}{l}\oplus \bigcirc \bigcirc \bigcirc \\
\text { VERY LOW }\end{array}$ & CRITICAL \\
\hline \multicolumn{10}{|c|}{ Weight Change (assessed with: Pre-post weight measures) } \\
\hline 1 & $\begin{array}{l}\text { Case } \\
\text { Report }\end{array}$ & $\begin{array}{l}\text { very } \\
\text { serious }^{a}\end{array}$ & not serious & not serious & not serious & none & $\begin{array}{l}\text { In one case report }(n=6) \text { study } \\
\text { change in weight was reported in } \mathrm{kg} \\
\text { and rose a mean of } 8.8 \mathrm{~kg} \text { from } \\
\text { admission to discharge }(n=5)\end{array}$ & $\begin{array}{l}\oplus \bigcirc \bigcirc \bigcirc \\
\text { VERY LOW }\end{array}$ & CRITICAL \\
\hline
\end{tabular}

\section{Explanations}

a Observational study with no comparison/control

Bibliography:

Case Series - Lock 2003 [234], Jenkins 1987 [233], Meilleur 2012 [235]

Case Report - Maxmen 1974 [232] 
Table 47 Multi-family therapy during inpatient treatment versus multi-parent therapy during inpatient treatment for children and adolescents with eating disorders

\begin{tabular}{|c|c|c|c|c|c|c|c|c|}
\hline \multicolumn{6}{|c|}{ Certainty assessment } & \multirow[t]{2}{*}{ Impact } & \multirow[t]{2}{*}{ Certainty } & \multirow[t]{2}{*}{ Importance } \\
\hline $\begin{array}{l}\text { № of } \\
\text { studies }\end{array}$ & $\begin{array}{l}\text { Study } \\
\text { design }\end{array}$ & $\begin{array}{l}\text { Risk of } \\
\text { bias }\end{array}$ & Inconsistency Indirectness & Imprecision & $\begin{array}{l}\text { Other } \\
\text { considerations }\end{array}$ & & & \\
\hline
\end{tabular}

Change in eating disorder symptomatology (assessed with: Pre/post EDI-2)

$1 \quad$ Case serious ${ }^{a}$ not serious not serious not serious none

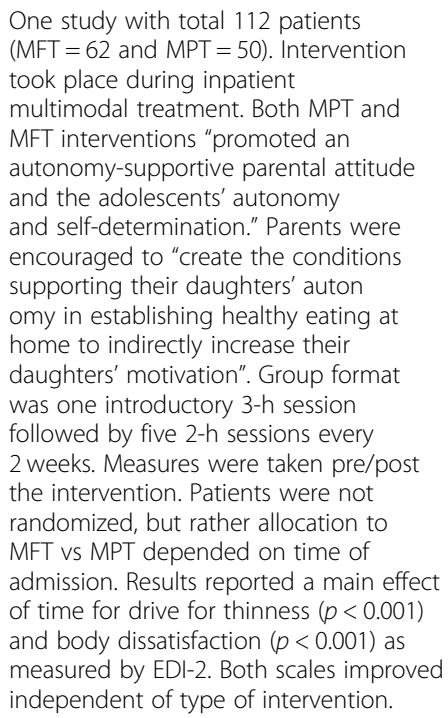

One study with total 112 patients (MFT = 62 and MPT =50). Intervention took place during inpatient multimodal treatment. Both MPT and MFT interventions "promoted an autonomy-supportive parental attitude and the adolescents' autonomy and self-determination." Parents were encouraged to "create the conditions supporting their daughters' auton omy in establishing healthy eating at home to indirectly increase their daughters' motivation". Group format was one introductory 3-h session followed by five 2-h sessions every 2 weeks. Measures were taken pre/post the intervention. Patients were not randomized, but rather allocation to MFT vs MPT depended on time of admission. Results reported a main effect of time for drive for thinness $(p<0.001)$ and body dissatisfaction $(p<0.001)$ as measured by EDI-2. Both scales improved independent of type of intervention.

\section{$\oplus \bigcirc \bigcirc \bigcirc$ IMPORTANT \\ VERY LOW}

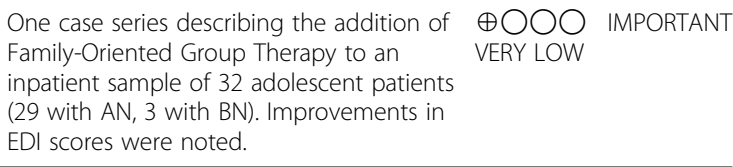

Explanations

${ }^{\text {a}}$ Due to design, no blinding possible Bibliography:

Case Control - Depestele 2017 [236]

Case Series - Salbach 2006 [237]

\section{Bright light therapy}

Anorexia nervosa and major depressive disorder One study of patients with AN and depressive symptoms admitted to a CBT-based inpatient program and treated adjunctively with Bright Light Therapy was found [242] (Table 50). In this study patients were randomized to receive either daily $30 \mathrm{~min}$ Bright Light Therapy $(\mathrm{BLT})+$ inpatient treatment $(n=12)$ for 6 weeks or inpatient treatment only for 6 weeks $(n=$ 12). Patients in both groups had a significant change in their BMI during the 6-week study, however change from baseline was statistically significant by week $3(p=0.038)$ in BLT group versus by week 6 $(p=0.048)$ in the comparison group.

\section{Cognitive remediation therapy}

Anorexia nervosa Four studies reported on the addition of Cognitive Remediation Therapy (CRT) to multimodal inpatient treatment [243-246] (Table 51). One study described change in weight between patients who received 10 sessions of CRT over 10 weeks versus those who received TAU in a quasi-experimental design $(n=$ 24 in each group) [244]. Both groups gained weight at a similar rate. The other studies reported on patients (total 79 patients) who received either 4 or 10 sessions of CRT provided as once weekly sessions. In all three studies patients gained weight. Given the design of these last three studies it was not possible to determine whether CRT had an impact on weight above and beyond what would have been expected by inpatient treatment alone.

Several studies of CRT added to inpatient treatment for AN reported on symptom change. One study included a description of two patients who received 10 sessions of CRT over 10 weeks in addition to multimodal inpatient treatment [243]. Scores on EAT decreased for one patient (30 to 16) and increased in the other patient (35 to 36 ). One study, including 125 hospitalized patients [246], received either group $(n=55)$ or individual $(n=70)$ CRT. Only those patients receiving individual 
Table 48 Meal support during inpatient treatment versus no meal support be used in the treatment of children and adolescents with eating disorders

\begin{tabular}{|c|c|c|c|c|c|c|c|c|c|}
\hline \multicolumn{7}{|c|}{ Certainty assessment } & \multirow[t]{2}{*}{ Impact } & \multirow[t]{2}{*}{ Certainty } & \multirow[t]{2}{*}{ Importance } \\
\hline $\begin{array}{l}\text { № of } \\
\text { studies }\end{array}$ & $\begin{array}{l}\text { Study } \\
\text { design }\end{array}$ & $\begin{array}{l}\text { Risk of } \\
\text { bias }\end{array}$ & Inconsistency & Indirectness & Imprecision & $\begin{array}{l}\text { Other } \\
\text { considerations }\end{array}$ & & & \\
\hline \multicolumn{10}{|c|}{ Rate of Weight Gain (assessed with: Measures of Weight Gain in Kg/Day), Need for NGT Feeds (assessed with: \# of Patients Receiving NGT Feeds) } \\
\hline \multirow[t]{2}{*}{3} & $\begin{array}{l}\text { Case } \\
\text { Control }\end{array}$ & serious $^{a}$ & serious $^{b}$ & not serious & serious $^{c}$ & $\begin{array}{l}\text { all plausible } \\
\text { residual } \\
\text { confounding would } \\
\text { reduce the } \\
\text { demonstrated } \\
\text { effect }\end{array}$ & $\begin{array}{l}\text { Three studies examined the } \\
\text { effect of meal support/ } \\
\text { supervision as part of inpatient } \\
\text { treatment for a total number of } \\
\text { patients receiving meal support } \\
\text { of } 88 \text { patients. There were no } \\
\text { significant differences between } \\
\text { cohorts who received meal } \\
\text { support and those who did not } \\
\text { on the rate of weight gain per } \\
\text { day or week,although there } \\
\text { was a trend towards greater } \\
\text { weight gain } / \text { day or week in } \\
\text { the group who received meal } \\
\text { support. Weight gain varied } \\
\text { from } 0.09 \mathrm{~kg} / \text { day to } 0.35 \mathrm{~kg} / \text { day } \\
\text { across studies. }\end{array}$ & $\begin{array}{l}\oplus \bigcirc \bigcirc \bigcirc \\
\text { VERY LOW }\end{array}$ & CRITICAL \\
\hline & & serious $^{d}$ & not serious & not serious & not serious & $\begin{array}{l}\text { strong association } \\
\text { all plausible } \\
\text { residual } \\
\text { confounding would } \\
\text { reduce the } \\
\text { demonstrated } \\
\text { effect }\end{array}$ & $\begin{array}{l}\text { One study of these studies } \\
\text { reported on difference in the } \\
\text { rate of NGT feeds in cohort of } \\
\text { patients treated on inpatient } \\
\text { unit before the institution of } \\
\text { consistent meal support vs } \\
\text { after. } 8 / 12 \text { patients not } \\
\text { receiving meal support (ie } \\
66.7 \%) \text { and } 1 / 9(11.1 \%) \text { of those } \\
\text { receiving meal support } \\
\text { required NGT feeds as part of } \\
\text { inpatient admission. }\end{array}$ & $\begin{array}{l}\oplus \oplus \oplus \bigcirc \\
\text { MODERATE }\end{array}$ & IMPORTANT \\
\hline
\end{tabular}

\section{Explanation}

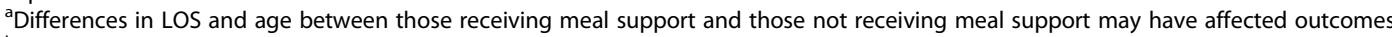

${ }^{b}$ Wide variation in \# of meals/day supervised between various studies

'Wide confidence intervals in some studies/groups

${ }^{d}$ Criteria for initiating NGT feeds somewhat vague (ie "consistent failure" to meet expected weight gain and/or acute refusal of food Bibliography:

Case Control - Kells 2013 [239], Kells 2017 [240], Couturier 2009 [238]

CRT completed the EDE-Q pre-post. Patients receiving individual CRT did not experience a change in their EDE-Q global score over the course of the 10 weeks they received CRT. One additional case report describes 10 sessions of CRT delivered to an inpatient with AN. Improvements on the EAT were observed [247].

One study, comprising 70 hospitalized patients who received multimodal inpatient treatment along with 10 individual sessions of CRT over 10 weeks reported on change in motivation as measured by the Motivational Stages of Change for Adolescents Recovering from an Eating Disorder (MSCARED) [246]. Patients completed the MSCARED before and after the course of CRT. There was a statistically significant improvement in motivation noted. Due to the design of this study it was not possible to differentiate the effect of inpatient treatment alone from inpatient treatment plus CRT.

\section{Inpatient and day treatment combined}

Anorexia nervosa Five reports on 265 patients with AN treated as inpatients followed immediately by day treatment were found [200, 248-251] (Table 52). In all five studies, patients were treated as inpatients and then transferred to day treatment once medically stable. Details regarding the number of hours/days spent in day treatment were not thoroughly reported, although mean length of stay varied from 7.9 weeks to 3.9 months. Weight change was reported in various ways, however, all studies indicated improvement in weight.

Symptom change was reported using various scales in these studies. One study included 35 patients with a mean length of stay of 15.1 weeks [251]. Change in EDI total, drive for thinness and body dissatisfaction were not significantly different between admission 
Table 49 Non-selective menus during inpatient treatment versus selective menus for children and adolescents with anorexia nervosa

\begin{tabular}{|c|c|c|c|c|c|c|c|c|c|}
\hline \multicolumn{7}{|c|}{ Certainty assessment } & \multirow[t]{2}{*}{ Impact } & \multirow[t]{2}{*}{ Certainty } & \multirow[t]{2}{*}{ Importance } \\
\hline $\begin{array}{l}\text { № of } \\
\text { studies }\end{array}$ & $\begin{array}{l}\text { Study } \\
\text { design }\end{array}$ & $\begin{array}{l}\text { Risk of } \\
\text { bias }\end{array}$ & Inconsistency & Indirectness & Imprecision & $\begin{array}{l}\text { Other } \\
\text { considerations }\end{array}$ & & & \\
\hline \multicolumn{10}{|c|}{ Rate of Weight Gain (assessed with: Weekly weight gain in kg/week), EDE Scores } \\
\hline \multirow[t]{2}{*}{1} & $\begin{array}{l}\text { Case } \\
\text { Control }\end{array}$ & serious $^{a, b}$ & not serious & not serious & serious $^{c}$ & $\begin{array}{l}\text { all plausible } \\
\text { residual } \\
\text { confounding } \\
\text { would reduce the } \\
\text { demonstrated } \\
\text { effect }\end{array}$ & $\begin{array}{l}\text { One study including } 22 \text { patients } \\
\text { who received non-selective menus } \\
\text { compared to } 18 \text { patients who re } \\
\text { ceived selective menus. LOS varied } \\
\text { between groups (although non- } \\
\text { significant) with non-select patients } \\
\text { remaining in hospital a mean of } \\
60.3(+/-22.8 \text { ) days vs } 74.2 \\
\text { (+/-28.7) days in selective menus } \\
\text { group. Non-selective menu group } \\
\text { gained a mean of } 0.95 \mathrm{~kg} / \text { wk } \\
\text { (+/-0.35) and those in selective } \\
\text { menu group gained a mean of } \\
0.72 \mathrm{~kg} / \mathrm{wk}(+/-0.24) \text { ( } p=0.02 \text { ). }\end{array}$ & $\begin{array}{l}\text { ÐOOO } \\
\text { VERY } \\
\text { LOW }\end{array}$ & CRITICAL \\
\hline & & serious $^{\mathrm{a}, \mathrm{b}}$ & not serious & not serious & serious $^{c}$ & $\begin{array}{l}\text { all plausible } \\
\text { residual } \\
\text { confounding } \\
\text { would reduce the } \\
\text { demonstrated } \\
\text { effect }\end{array}$ & $\begin{array}{l}\text { No significant differences were } \\
\text { found on any of the EDE items } \\
\text { related to eating concern. Overall } \\
\text { change in EDE eating concern } \\
\text { scores were low ranging from }-0.6 \\
\text { to } 1.1 \text {. }\end{array}$ & $\begin{array}{l}\text { ÐOOO } \\
\text { VERY } \\
\text { LOW }\end{array}$ & IMPORTANT \\
\hline
\end{tabular}

Explanations

anclear whether groups differed at baseline as these details were not reported

${ }^{b}$ Cohort study design (pre/post introduction of non-selective menus), unclear if other aspects of care may have also varied between groups

${ }^{c}$ Confidence intervals relatively wide and overlap with actual difference in effect

Bibliography:

Case Control - Leacy 2012 [241]

Table 50 Bright light therapy during CBT-based inpatient treatment versus CBT-based inpatient treatment alone for children and adolescents with anorexia nervosa and major depressive disorder

\begin{tabular}{|c|c|c|c|c|c|c|c|c|c|}
\hline \multicolumn{7}{|c|}{ Certainty assessment } & \multirow[t]{2}{*}{ Impact } & \multirow[t]{2}{*}{ Certainty } & \multirow[t]{2}{*}{ Importance } \\
\hline $\begin{array}{l}\text { № of } \\
\text { studies }\end{array}$ & $\begin{array}{l}\text { Study } \\
\text { design }\end{array}$ & $\begin{array}{l}\text { Risk of } \\
\text { bias }\end{array}$ & Inconsistency & Indirectness & Imprecision & $\begin{array}{l}\text { Other } \\
\text { considerations }\end{array}$ & & & \\
\hline \multicolumn{10}{|c|}{ RCT - Change in Weight (assessed with: Change in BMl per week) } \\
\hline 1 & $\begin{array}{l}\text { randomised } \\
\text { trials }\end{array}$ & serious $^{a}$ & not serious & not serious & serious $^{b}$ & none & $\begin{array}{l}\text { One study randomized patients } \\
\text { with AN-R and depressive } \\
\text { symptoms (> } 17 \text { on HDRS) } \\
\text { admitted to CBT-based } \\
\text { inpatient treatment to receive } \\
\text { either daily } 30 \text { min BLT }+ \\
\text { inpatient treatment }(n=12) \times \\
6 \text { weeks or inpatient treatment } \\
\text { only } \times 6 \text { weeks ( } n=12 \text { ). } \\
\text { Patients in both groups had a } \\
\text { significant change in their BMI } \\
\text { during } 6 \text { week study, however } \\
\text { change from baseline was } \\
\text { statistically significant by week } \\
3 \text { ( } p=0.038 \text { in BLT group vs } \\
\text { only significant change from } \\
\text { baseline at week } 6 \text { ( } p=0.048 \text { ) } \\
\text { in TAU group. }\end{array}$ & $\begin{array}{l}\oplus \oplus \circ \bigcirc \\
\text { LOW }\end{array}$ & CRITICAL \\
\hline
\end{tabular}

Explanations

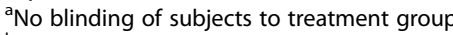

${ }^{b}$ Confidence intervals overlapping with actual size of treatment effect

Bibliography

RCT - Janas-Kozik 2011 [242] 
Table 51 Cognitive remediation therapy during inpatient treatment be used for the treatment of children and adolescents with anorexia nervosa

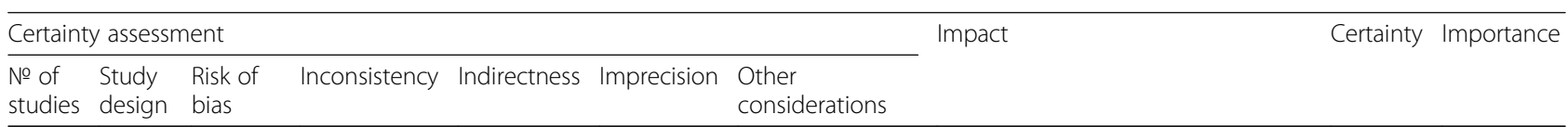

studies design bias

considerations

Change in Weight (assessed with: Pre/Post CRT Measures of Weight), change in EBRS, change in EDE-Q

3 Case/ very control serious ${ }^{\text {a }}$

not serious

Case

Series all plausible residual

confounding would reduce the demonstrated effect

very not serious not serious not serious
serious $^{b}$

very serious $^{a}$

not serious serious ${ }^{d}$

very serious $^{a}$ not serious

not serious not serious all plausible residual confounding would reduce the demonstrated effect

all plausible residual confounding would reduce the demonstrated effect

all plausible residual confounding would reduce the demonstrated effect
Three studies reported on addition of CRT to multimodal inpatient treatment. One study described

$\bigoplus$

VERY

LOW

who in weight between patients

who received 10 sessions of CRT

over 10 weeks vs those who

received TAU in a quasi-

experimental design ( $n=24$ in each group). Both groups gained weight at a similar rate (change from mean BMI\% of 2.2 to 5.7 over 10 weeks in CRT group vs mean BMI\% 5.5 to 7.6 over 10 weeks in TAU group). The other studies reported on patients (total 79 patients) who received either 4 or 10 sessions of CRT provided as once weekly sessions. In all 3 studies patients gained weight. Given the design of these studies it is not possible to deter mine whether CRT had an impact on weight above and beyond what would have been expected by in patient treatment alone.

One study included description of $2 \oplus 000$ patients who received 10 sessions VERY of CRT over 10 weeks in addition to LOW

IMPORTANT multimodal inpatient treatment. EBRS scores decreased slight for both patients from 26 to 22 and 29 to 26 at end of 10 weeks.

One study, including 125 hospitalized patients. Received VERY either group $(n=55)$ or individual LOW

IMPORTANT dividual CRT completed the EDE-Q. pre-post. Patients receiving individual CRT did not experience a change in their EDE-Q global score over the course of the 10 weeks where they received $C R T$.

One study, comprising 70 multimodal inpatient treatment along with 10 individual sessions of CRT over 10 weeks. Patients completed the MSCARED before and after the course of CRT. There was a statistically significant shift in motivation noted $(p<0.001)$, where at initiation of CRT \% of patients in each stages of change category were as follows: pre-contemplation 18.6\%, contemplation 38.6\%, prepar ation $28.6 \%$, action $11.4 \%$, mainten ance $2.9 \%$. At the end of CRT \% of patients in each stage of change were: pre-contemplation $0 \%$, con templation $4.3 \%$, preparation $31.4 \%$, action $42.9 \%$, maintenance $21.4 \%$, 
Table 51 Cognitive remediation therapy during inpatient treatment be used for the treatment of children and adolescents with anorexia nervosa (Continued)

\begin{tabular}{|c|c|c|c|c|c|c|c|c|c|}
\hline \multicolumn{7}{|c|}{ Certainty assessment } & \multirow[t]{2}{*}{ Impact } & \multirow[t]{2}{*}{ Certainty } & \multirow[t]{2}{*}{ Importance } \\
\hline $\begin{array}{l}\text { № of } \\
\text { studies }\end{array}$ & $\begin{array}{l}\text { Study } \\
\text { design }\end{array}$ & $\begin{array}{l}\text { Risk of } \\
\text { bias }\end{array}$ & Inconsistency & Indirectness & Imprecision & $\begin{array}{l}\text { Other } \\
\text { considerations }\end{array}$ & & & \\
\hline & & & & & & & $\begin{array}{l}\text { Due to the design of this study it is } \\
\text { not possible to differentiate the } \\
\text { effect of inpatient treatment alone } \\
\text { from inpatient treatment + CRT. }\end{array}$ & & \\
\hline & & $\begin{array}{l}\text { very } \\
\text { serious }\end{array}$ & serious $^{c}$ & not serious & not serious & $\begin{array}{l}\text { all plausible } \\
\text { residual } \\
\text { confounding } \\
\text { would reduce the } \\
\text { demonstrated } \\
\text { effect }\end{array}$ & $\begin{array}{l}\text { One study included description of } \\
2 \text { patients who received } 10 \text { sessions } \\
\text { of CRT over } 10 \text { weeks in addition } \\
\text { to multimodal inpatient treatment. } \\
\text { Scores on EAT decreased for one } \\
\text { patient ( } 30 \text { to } 16 \text { ) and increased } \\
\text { in the other patient ( } 35 \text { to } 36 \text { ). }\end{array}$ & $\begin{array}{l}\text { 円OOO } \\
\text { VERY } \\
\text { LOW }\end{array}$ & IMPORTANT \\
\hline \multicolumn{10}{|c|}{ Weight, EAT-26 } \\
\hline \multirow[t]{2}{*}{2} & $\begin{array}{l}\text { Case } \\
\text { reports }\end{array}$ & $\begin{array}{l}\text { very } \\
\text { serious }\end{array}$ & serious $^{c}$ & not serious & not serious & $\begin{array}{l}\text { all plausible } \\
\text { residual } \\
\text { confounding } \\
\text { would reduce the } \\
\text { demonstrated } \\
\text { effect }\end{array}$ & $\begin{array}{l}\text { One study involved } 7 \text { adolescents } \\
\text { inpatients with AN using group } \\
\text { CRT. Weight improved as did } \\
\text { motivation. }\end{array}$ & $\begin{array}{l}\text { 円OOО } \\
\text { VERY } \\
\text { LOW }\end{array}$ & IMPORTANT \\
\hline & & $\begin{array}{l}\text { very } \\
\text { serious }\end{array}$ & serious $^{c}$ & not serious & not serious & $\begin{array}{l}\text { all plausible } \\
\text { residual } \\
\text { confounding } \\
\text { would reduce the } \\
\text { demonstrated } \\
\text { effect }\end{array}$ & $\begin{array}{l}\text { Another study is a single case } \\
\text { report describing improvement } \\
\text { on the EAT- } 26 \text { after } 10 \text { sessions } \\
\text { of CRT with an inpatient with AN. }\end{array}$ & $\begin{array}{l}\text { ĐOO० } \\
\text { VERY } \\
\text { LOW }\end{array}$ & IMPORTANT \\
\hline
\end{tabular}

\section{Explanations}

${ }^{\mathrm{a}}$ Not all studies had comparison group and were receiving inpatient treatment which could account for some of the differences observed/reported

${ }^{b}$ Case report design, no comparison/control

${ }^{c}$ Differing results between the 2 reports likely secondary to individual differences

${ }^{d}$ Wide confidence intervals, overlapping with with the size of the effect noted

Bibliography:

Case control - Herbrich 2017 [244], Harrison 2018 [246]

Case series - Asch 2014 [243]

Case reports - Kuge 2017 [245], Cwojdzinska 2009 [247]

and discharge. One study included 26 adolescents who received 13 weeks of inpatient treatment based on the Cognitive Behavioural Therapy- Enhanced (CBT-E) model followed by 7 weeks of Day Treatment Program (DTP) [249]. EDE scores decreased significantly pre-post for global score and all subscales other than Shape Concern. This study also reported on frequency of eating disorder symptoms. Binge eating was present in eight patients $(30 \%)$ at admission and only two patients (7.7\%) at discharge. Purging by vomiting was present at admission for 10 patients (28.5\%) and at discharge for 4 patients (15.1\%). Laxative misuse was present for 3 patients at admission and none at discharge.

One study reported on change in motivation as measured by the ANOSCQ in 35 patients [251]. These patients received 15.1 weeks of inpatient and day treatment. Overall scores increased a mean of 21.7 points, which signified moving from contemplation to preparation phases.
One study which included 71 patients who completed 7.9 weeks of combined inpatient and DTP (33 days inpatient and 22 days DTP) reported on "overall outcome" [200]. At the end of DTP $35.2 \%$ were deemed to have an excellent outcome, $26.8 \%$ were deemed good outcome, $14.1 \%$ deemed below average outcome and $23.9 \%$ were deemed to have a poor outcome.

\section{Admission to weight restoration versus short admission for medical stabilization with either FBT or day treatment}

Anorexia nervosa Two high quality studies examined the difference between patients randomized to receive a relatively short inpatient admission followed by either 20 sessions of FBT $(n=82)$ [252] or Day Treatment $(n=172)$ [253] compared to a lengthy inpatient stay to weight restoration (Table 53). In the Inpatient/FBT study [252] 
Table 52 Inpatient and day treatment in combination for children and adolescents with anorexia nervosa

\begin{tabular}{|c|c|c|c|c|c|c|}
\hline \multicolumn{7}{|c|}{ Certainty assessment } \\
\hline $\begin{array}{l}\text { № of } \\
\text { studies }\end{array}$ & $\begin{array}{l}\text { Study } \\
\text { design }\end{array}$ & $\begin{array}{l}\text { Risk of } \\
\text { bias }\end{array}$ & Inconsistency & Indirectness & Imprecision & $\begin{array}{l}\text { Other } \\
\text { consi }\end{array}$ \\
\hline \multicolumn{7}{|c|}{ Weight Change (assessed with: Change in weight during treatment) } \\
\hline 5 & $\begin{array}{l}\text { Case } \\
\text { Control } \\
\text { and } \\
\text { Case } \\
\text { Series }\end{array}$ & $\begin{array}{l}\text { very } \\
\text { serious a }\end{array}$ & not serious & not serious & not serious & none \\
\hline
\end{tabular}
Impact

Certainty Importance
Eating Disorder Inventory - 2 Score at discharge (assessed with: Rating Scale)
1 Case very not serious not serious not serious none Series serious ${ }^{a, b}$

Anorexia Nervosa Stages of Change Questionnaire (assessed with: Rating Scale)

$1 \quad \begin{array}{ll}\text { Case } & \text { very } \\ \text { Series } & \text { serious }^{\text {a,c }}\end{array}$ not serious not serious serious ${ }^{d}$

all plausible residual confounding would reduce the demonstrated effect

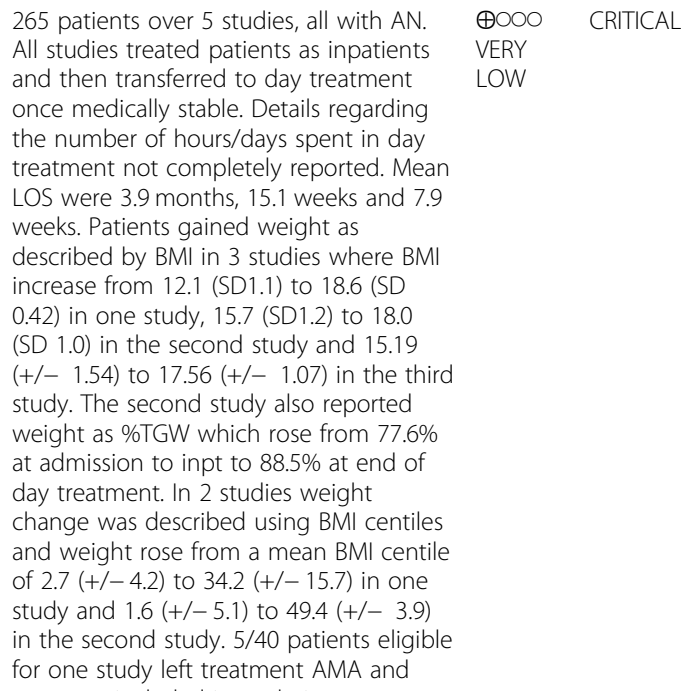

265 patients over 5 studies, all with AN. All studies treated patients as inpatients and then transferred to day treatment once medically stable. Details regarding the number of hours/days spent in day treatment not completely reported. Mean LOS were 3.9 months, 15.1 weeks and 7.9 weeks. Patients gained weight as described by BMI in 3 studies where BMI increase from 12.1 (SD1.1) to 18.6 (SD 0.42) in one study, 15.7 (SD1.2) to 18.0 (SD 1.0) in the second study and 15.19 $(+/-1.54)$ to $17.56(+/-1.07)$ in the third study. The second study also reported weight as \%TGW which rose from $77.6 \%$ at admission to inpt to $88.5 \%$ at end of day treatment. In 2 studies weight change was described using BMI centiles and weight rose from a mean $\mathrm{BMI}$ centile of $2.7(+/-4.2)$ to $34.2(+/-15.7)$ in one study and $1.6(+/-5.1)$ to $49.4(+/-3.9)$ in the second study. 5/40 patients eligible for one study left treatment AMA and

$\oplus \circ O \bigcirc$

VERY

LOW

CRITICAL were not included in analysis.

35 patients completed inpt, day treatment and measures. Mean LOS 15.1 weeks. Change in ED1-2 total, drive for thinness and body dissatisfaction not significantly different between admission and discharge.

35 patients completed ANSOCQ at admission and $d / c$ (ie after 15.1 weeks of VERY inpatient + day treatment). Overall score increased a mean of 21.7 points which would signify moving from contemplation to preparation phases. Overall 29.4\% (up from 0\% at admission) of patients were classified as in "maintenance phase" and 26.5\% (up from $15 \%$ at admission) in "action phase" at time of discharge.

Overall Outcome (assessed with: Rating combining weight + compensatory symptoms)

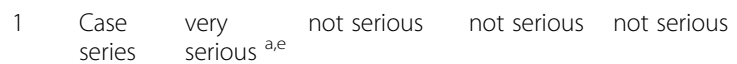
residual confounding would reduce the demonstrated effect $\oplus \circ \circ \bigcirc$ LOW

VERY

LOW

IMPORTANT

IMPORTANT
One study which included 71 patients who completed 7.9 weeks of combined inpatient and DTP (33 days inpatient and 22 days DTP). At end of DTP $35.2 \%$ were deemed to have an excellent outcome (> 90\% ideal BMI, maintaining weight and no use of compensatory symptoms in last week of program), $26.8 \%$ were deemed good outcome $(85-90 \%$ ideal BMI, maintaining weight and no use of compensatory symptoms in last week of treatment), $14.1 \%$ deemed below average outcome $(80-85 \%$ ideal BMl and maintaining weight $\mathrm{OR}>85 \%$ ideal $\mathrm{BMI}$, but losing $0.15-0.45 \mathrm{~kg} /$ week with no compensatory symptoms in the last week of treatment) and $23.9 \%$ were deemed to have a poor outcome (either $<80 \%$ ideal $\mathrm{BMI} \mathrm{OR}<85 \%$ ideal $\mathrm{BMI}$ and losing $>0.15$ $\mathrm{kg} /$ week OR readmitted to inpatient unit $\mathrm{OR}$ use of compensatory symptoms in 
Table 52 Inpatient and day treatment in combination for children and adolescents with anorexia nervosa (Continued)

\begin{tabular}{lllll}
\hline Certainty assessment & & \\
\hline № of & Study & Risk of & Inconsistency & Indirectness \\
studies & design & bias & & $\begin{array}{l}\text { Other } \\
\text { considerations }\end{array}$ \\
\hline
\end{tabular}
Impact

Eating Disorder Symptomatology (assessed with: Pre-post EDE-Q)

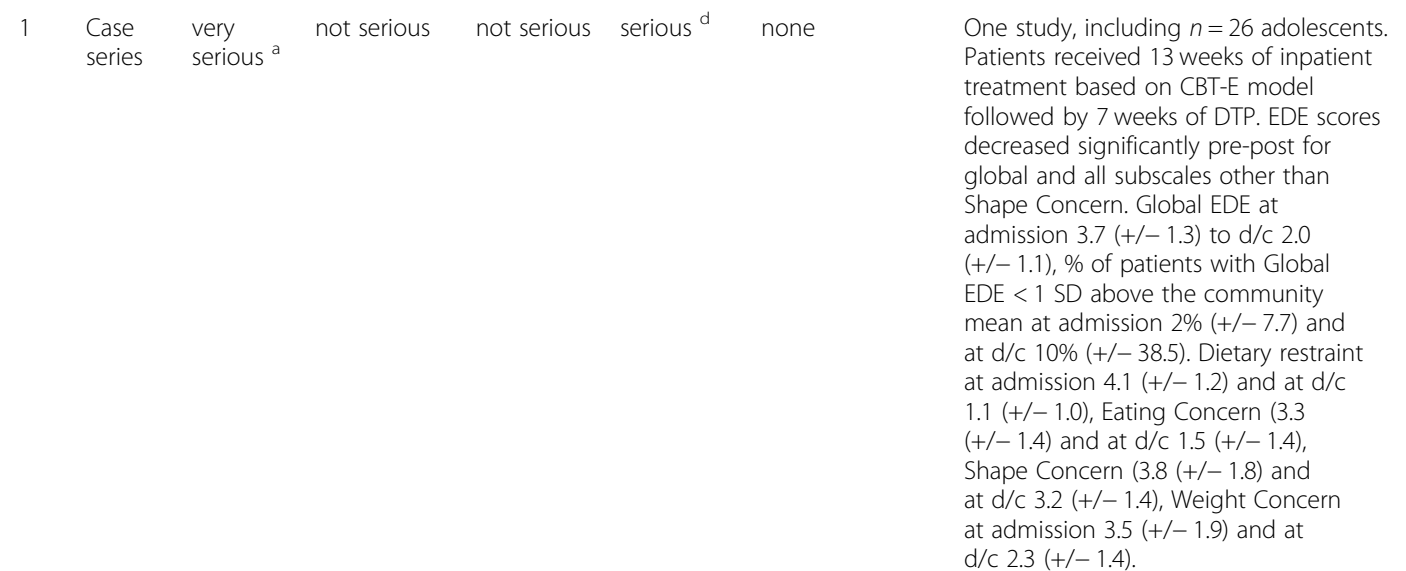

patients had all been unwell less than 3 years and in the inpatient/day treatment study [253] the patients were included only if it was their first admission. At the end of FBT or Day Treatment, there were no significant differences between those who were discharged after a short admission versus those who remained in hospital for weight restoration in terms of weight outcome, rate of readmissions over 12-month follow-up, or eating disorder symptoms [252, 253].

\section{Day treatment \\ Multimodal day treatment}

Anorexia nervosa Two case series and one case report describe the outcomes of patients treated in their multimodal day hospital programs [254-256] (Table 54). Admission to day treatment in these studies could occur from an inpatient setting or an outpatient setting based on clinical need. Weight related 
Table 53 Inpatient medical stabilization followed by outpatient treatment versus inpatient weight restoration for children and adolescents with anorexia nervosa

\begin{tabular}{|c|c|c|c|c|c|c|}
\hline \multicolumn{5}{|c|}{ Certainty assessment } & \multirow[t]{2}{*}{ Certainty } & \multirow[t]{2}{*}{ Importance } \\
\hline $\begin{array}{l}\text { № of } \\
\text { studies }\end{array}$ & $\begin{array}{l}\text { Study } \\
\text { design }\end{array}$ & $\begin{array}{l}\text { Risk of } \\
\text { bias }\end{array}$ & Inconsistency Indirectness Imprecision & $\begin{array}{l}\text { Other } \\
\text { considerations }\end{array}$ & & \\
\hline
\end{tabular}

Change in weight (assessed with: Pre/post measures of weight), Rate of Readmission, psychological symptoms (EDE and EDI)

2 randomised serious ${ }^{a}$ not serious not serious not serious none trials
Two RCT examined the difference between patients randomized to receive a relatively short inpatient admission followed by either 20 sessions of FBT $(n=82)$ or DTP $(n=172)$. In the FBT F/U study patients had all been unwell less than 3 years and in the day treatment F/U study the patients we only included if it was their first admission. The first study randomized patients to be $d / c$ once medically stable (mean LOS $21.73+/-5.92$ days) vs to remain in hospital until 90\%TGW (mean LOS 36.89 +/17.06). Both groups received 20 sessions of FBT following discharge. Patients discharged at point of medical stability (ie mean $84.40 \%$ TGW) had attained a mean of $95.20 \%$ TGW by the end of 20 sessions of FBT whereas those who remained in hospital until they were 90\%TGW (ie mean $92.00 \%$ TGW) were at a mean of $93.10 \%$ TGW by session 20. ES in this study was 1.28 at the end of hospitalization and 0.27 at end of session 20. There was a significant difference in weight at end of hospitalization, but not by end of session 20. The other study randomized patients to remain as inpatients for 3 weeks vs until attaining TGW (total mean treatment time 14.6 weeks). Those $d / c$ at 3 weeks entered a DTP with similar programming (total mean treatment time 16.5 weeks). At end of treatment patients in inpatient only group had reached a mean of 89\%TGW (+/-3.8) and those in inpt + DTP had reached 88.1\%TGW (+/- 4.7) - no significant difference in weight outcome in intention to treat analysis.

Both RCTs examined Rate of readmission measured over the 12 months following admission in the FBT-f/u study $(n=82)$. Re admission rates were similar re gardless of allocation (ie 35\% in med stability group vs $36.8 \%$ in the weight restoration group). However, given that the med stability group had a shorter $\oplus \oplus \oplus \circ$

CRITICAL MODERATE serious $^{a}$ not serious not serious not serious none $\oplus \oplus \oplus \circ$ MODERATE 
Table 53 Inpatient medical stabilization followed by outpatient treatment versus inpatient weight restoration for children and adolescents with anorexia nervosa (Continued)

\begin{tabular}{|c|c|c|c|c|c|c|c|c|c|}
\hline \multicolumn{7}{|c|}{ Certainty assessment } & \multirow[t]{2}{*}{ Impact } & \multirow[t]{2}{*}{ Certainty } & \multirow[t]{2}{*}{ Importance } \\
\hline $\begin{array}{l}\text { № of } \\
\text { studies }\end{array}$ & $\begin{array}{l}\text { Study } \\
\text { design }\end{array}$ & $\begin{array}{l}\text { Risk of } \\
\text { bias }\end{array}$ & Inconsistency & Indirectness & Imprecision & $\begin{array}{l}\text { Other } \\
\text { considerations }\end{array}$ & & & \\
\hline & & & & & & & $\begin{array}{l}\text { initial admission, the total } \\
\text { hospital days was } 45.2 \mathrm{~d} \\
\text { in this group vs } 65.5 \text { in } \\
\text { the weight restoration } \\
\text { group. In inpatient weight } \\
\text { restoration vs DTP F/U } \\
8 / 87 \text { patients were } \\
\text { readmitted during their } \\
\text { DTPtreatment due to } \\
\text { medical instability and } \\
25.3 \% \text { (inpt WR) vs } 15.1 \% \\
\text { (DTP), } p=0.12 \text { required } \\
\text { readmission to inpatient } \\
\text { unit at } 12 \text { months F/U. }\end{array}$ & & \\
\hline & & serious $^{a}$ & not serious & not serious & not serious & none & $\begin{array}{l}\text { One study - EDI-2 scores } \\
\text { pre treatment and post } \\
\text { treatment similar between } \\
\text { groups regardless of } \\
\text { allocation (total } n=143 \text { ). }\end{array}$ & $\begin{array}{l}\oplus \oplus \oplus O \\
\text { MODERATE }\end{array}$ & IMPORTANT \\
\hline & & serious $^{a}$ & not serious & not serious & not serious & none & $\begin{array}{l}\text { One study - EDE global } \\
\text { scores not significantly } \\
\text { different between groups } \\
\text { at baseline or at end of } \\
\text { FBT, } 6 \text { month or } 12 \text { month } \\
\text { F/U }(n=69) \text {. }\end{array}$ & $\begin{array}{l}\oplus \oplus \oplus \mathrm{O} \\
\text { MODERATE }\end{array}$ & IMPORTANT \\
\hline
\end{tabular}

Explanations

${ }^{a}$ No blinding of participants possible

Bibliography:

RCT - Herpertz-Dahlmann 2014 [253], Madden 2015 [252]

outcomes were reported in various ways. Improvements in BMI from admission to discharge were described [255]. Two studies reported improvements in \%TGW at admission and discharge [255, 256]. One study reported an increase in weight from 81.6 to 84.2\% TGW [255]. The other study reported weight change separately for patients above and below $85 \%$ TGW at admission and found both cohorts gained weight [256]. Mean length of stay varied between 70 to 92 days. One case report described a weight change from $87 \mathrm{lbs}$ to $101 \mathrm{lbs}$ over the admission to the day program [254].

One study examined eating disorder psychological symptoms with 26 patients remaining in DTP for mean length of 10 weeks [255]. EDI scores for Drive for Thinness and Perfectionism improved significantly, whereas body dissatisfaction and maturity fears did not change significantly.

Two studies reported on percent of patients successfully completing the day treatment program $[255,256]$. Definition of "successful completion" was based on a combination of symptom change, weight gain and progression in program (versus leaving against medical advice (AMA) or need for admission to an inpatient unit).
Mean length of stay ranged from 11.6 to 15.3 weeks. Successful completion rates in these studies were 30 to $50 \%$. One study examined whether completion rate varied between those that started at greater than or less that $85 \%$ TGW, and reported that there was no difference based on this factor [256].

Mixed diagnoses Several studies address mixed diagnoses of eating disorders within a multimodal day hospital program [257-261] (Table 55). Weight in all studies improved over the course of day treatment. Weight gain was correlated with a diagnosis of $\mathrm{AN}$ or EDNOS (versus BN), longer length of stay and lower weight at admission [261]. The length of stay in these studies varied between 15.3 weeks and 13.1 weeks.

Lazaro and colleagues [259] reported outcomes separately for those with $\mathrm{AN}$ and $\mathrm{BN}$ within their day treatment program. The sample size was 160 patients (116 $\mathrm{AN}$ patients and $44 \mathrm{BN}$ patients). Mean length of stay was 15 weeks. For both groups, self-esteem improved in relation to others and in relation to weight and shape. No significant differences were found between the AN and $\mathrm{BN}$ groups [259]. 
Table 54 Multimodal day treatment be used in the treatment of children and adolescents with anorexia nervosa

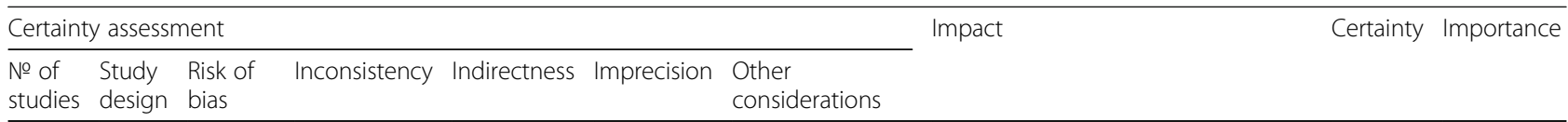

Weight Gain From Admission to Discharge (assessed with: BMI/\%TGW/Wt), EDI-3, EAT-26, Motivation, successful completion (\%)

2 Case very $_{\text {Series }}$ serious $^{\text {a }}$ serious $^{b}$ not serious serious ${ }^{c}$

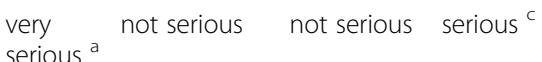

very

serious not serious not serious serious ${ }^{c}$

(1)

all plausible

residual

confounding

would reduce the

demonstrated

effect

all plausible

residual

confounding

would reduce the

demonstrated

effect

Admission to DTP could occur from inpatient setting or outpatient $\oplus \bigcirc \bigcirc \bigcirc$

CRITICAL setting based on clinical judgment LOW of need for this level of care. Weight related outcomes reported in various ways. One study reported admission and discharge BMI with a change from 16.5 (SD 1.5) to 17.1 (SD 1.9). Two studies reported $\%$ TGW at admission and discharge. One reported an increase in weight from 81.6 to $84.2 \%$ TGW. The other study reported weight change separately for patients above and below 85\%TGW at admission. For those $<85 \%$ TGW at admission, TGW rose from 81.5 to $88.3 \%$, in those $>$ 85\%TGW at admission \%TGW rose from 88.0 to $92.2 \%$.. Mean LOS varied between 70 to 92 days.

One study - 26 patients in study, remained in DTP for mean LOS of 10 weeks. Eighty-five \% of patients were referred to DTP from out patient setting, remainder from in patient program. Only criterion from admission to DTP vs inpatient was medical stability. EDI-3 scores for Drive for Thinness and Perfectionism improved significantly with Drive for Thinness changing from 13.81 (SD 9.08) to 10.08 (SD 8.32) and Perfec tionism changing from 8.96 (6.79) to 8.19 (SD 6.87), signifying a small ef fect size ( 0.43 and 0.11 respectively). Body dissatisfaction and maturity fears did not change significantly during course of DTP.

One study - 26 patients in study, remained in DTP for mean LOS of 10 weeks. EAT-26 scores decreased

all plausible residual confounding would reduce the from 28.08 (SD 20.61) at admission demonstrated effect to 22.19 (SD 19.34) at discharge which signifies a small effect size (ie 0.30).

One study - 26 patients in study, remained in DTP for mean LOS of 10 weeks. ANSOCQ score changed

all plausible residual confounding would reduce the from 53.48 (SD 20.42) to 65.63 (SD demonstrated 21.27) signifying no change in effect "stage" (patients remained in "preparation phase" throughout).

Two studies reported on "\% completing" the DTP, including 53 patients with AN. Definition of "successful completion" was based on a combination of symptom change, weight gain and progression in program (vs leaving AMA or need for admission to inpatient unit). Mean LOS ranged $\bigoplus 00 \bigcirc$

VERY

LOW

IMPORTANT

$\bigoplus 000$

VERY

LOW

Đ૦००

VERY

LOW

$\bigoplus 000$

VERY

LOW

IMPORTANT

IMPORTANT

OOOO
VEY
OW

CRITICAL 
Table 54 Multimodal day treatment be used in the treatment of children and adolescents with anorexia nervosa (Continued)

\begin{tabular}{|c|c|c|c|c|c|c|c|}
\hline \multicolumn{6}{|c|}{ Certainty assessment } & \multirow[t]{2}{*}{ Impact } & \multirow[t]{2}{*}{ Certainty Importance } \\
\hline $\begin{array}{l}\text { № of } \\
\text { studies }\end{array}$ & $\begin{array}{l}\text { Study } \\
\text { design }\end{array}$ & $\begin{array}{l}\text { Risk of } \\
\text { bias }\end{array}$ & Inconsistency Indirectness & Imprecision & $\begin{array}{l}\text { Other } \\
\text { considerations }\end{array}$ & & \\
\hline & & & & & & $\begin{array}{l}\text { from } 11.6 \text { to } 15.3 \text { weeks. "Successful } \\
\text { Completion" rates in these studies } \\
\text { were } 30 \text { to } 50 \% \text {. One study } \\
\text { examined whether completion rate } \\
\text { varied between those that started at } \\
\text { greater than or less that } 85 \% \text { TGW, } \\
\text { and reported that there was no } \\
\text { difference based on this factor. }\end{array}$ & \\
\hline
\end{tabular}

Weight

\begin{tabular}{|c|c|c|c|c|c|c|}
\hline $\begin{array}{l}\text { Case } \\
\text { report }\end{array}$ & $\begin{array}{l}\text { very } \\
\text { serious a }\end{array}$ & serious $^{b}$ & not serious serious ${ }^{c}$ & $\begin{array}{l}\text { all plausible } \\
\text { residual } \\
\text { confounding } \\
\text { would reduce the } \\
\text { demonstrated } \\
\text { effect }\end{array}$ & $\begin{array}{l}\text { The case report described a weight } \\
\text { change from } 87 \mathrm{lbs} \text { to } 101 \mathrm{lbs} \text {. over } \\
\text { the DTP admission }\end{array}$ & $\begin{array}{l}\oplus O O O \\
\text { VERY } \\
\text { LOW }\end{array}$ \\
\hline
\end{tabular}

Explanations

a Observational study, no comparison/control

${ }^{b}$ Varying BMI/TGW at admission to various programs, programs provided differing levels/hours of support and results on this outcome varied

${ }^{c}$ Confidence intervals wider than actual effect in some studies

Bibliography:

Case series - Ngo 2014 [256], Goldstein 2011 [255]

Case reports - Garner 2002 [254]

Two studies treating mixed diagnoses of eating disorders for total of 61 patients looked at successful completion of the program [257, 258]. Success was defined using various criteria such as adequate weight gain, symptom reduction, and no AMA discharge or inpatient admission. Success rate was $49 \%$ [258] and 50\% [257].

One study including 30 patients with mixed diagnoses examined motivational stage of change [260]. Length of stay was 10.5 weeks. Motivational Stage of Change was measured pre-post with the MSCARED [260]. Patients were noted to progress through the stages of change during treatment. The change in stage of change from intake to discharge was significantly correlated with the change in the Children's Eating Attitudes Test (ChEAT) score during the same time period [260].

\section{Family-based day treatment}

Anorexia nervosa/low weight eating disorders Nine studies for a total of 427 patients examined a familybased day treatment program [262-270] (Table 56). Studies varied with regards to the degree to which they included parents in treatment, number of hours/week of programming and length of stay. Criteria for admission to the day treatment program varied.

Five studies reported improvement in BMI [264, 265, 268-270]. Three studies reported on total weight gained in program [262, 263, 269]. Two studies reported on change in \%TGW which rose from 83 to $93 \%$ in one study [266], and 83 to $98 \%$ in another study [269]. Length of stay in these studies varied from 28 days to 1.3 years.

One study reported on difference in weight outcomes between their Maudsley and non-Maudsley DTP, noting no difference between these two groups [264]. Another study reported on differences between patients who received "formal psychotherapy" (individual and/or family) outside of program thereby needing to leave program for approx $2 \mathrm{~h} /$ week and noted that patients who received external psychotherapy within the first 2 months of entering DTP gained significantly less weight [262]. One study examined predictors of weight restoration in DTP and reported that higher BMI at admission, greater gain in the first 4 weeks and lower caregiver empowerment at baseline were predictive of weight restoration at end of intensive treatment [269].

Six studies examined psychological symptoms with the EDE-Q [264, 266, 267, 269-271]. EDE-Q scores, global and all subscales decreased significantly in these studies. In a study reporting on a control group which was treated in the same program, but without the inclusion of Maudsley/family interventions, the EDE-Q scores decreased more in the Maudsley group than the non-Maudsley [264]. Of note the scores for Weight Concern and Restraint Concerns did not change significantly in the non-Maudsley group whereas they decreased significantly in the Maudsley group [264]. 
Table 55 Multimodal day treatment be used in the treatment of children and adolescents with eating disorders

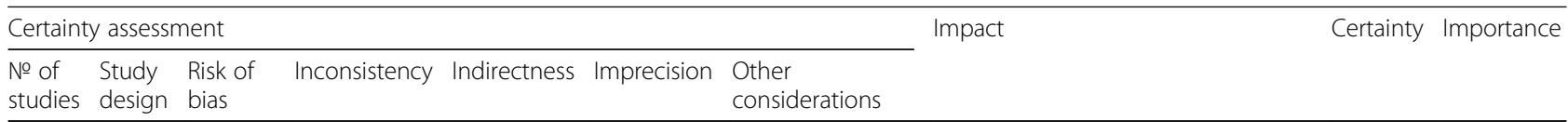

Weight Change (assessed with: BMI/TGW), Change in self esteem, successful completion, change in motivation

5 Case very not serious not serious serious ${ }^{b}$ none series serious ${ }^{\text {a }}$

$\begin{array}{ll}\begin{array}{l}\text { very not serious not serious serious }{ }^{b} \quad \\ \text { serious }^{a}\end{array} & \text { all plausible } \\ & \text { residual } \\ & \text { confounding } \\ & \text { would reduce the } \\ & \text { demonstrated } \\ & \text { effect }\end{array}$
criteria such as adequate weight

very not serious not serious not serious serious $^{\text {a }}$

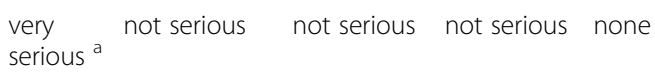

all plausible residual confounding would reduce the demonstrated effect
Reasons for referral to DTP were based on severity of symptomatology, but could occur from inpatient or outpatient or initial assessment. Two studies reported all patients together, the other $(n=160)$ reported AN $(n=$ 116) vs BN $(n=44)$. In one mixed study the mean BMI rose from 18.9 (SD 2.6) to 20.9 (SD 2.9) which related to a change in \%TGW from $94 \%$ at admission to $102 \%$ at discharge. In the other mixed study the weight gain was reported as $0.95 \mathrm{~kg}$ over the 2.6 weeks LOS. It was noted that approx one-quarter of patients lost weight, one quarter gained $0-0.9 \mathrm{~kg}$, on quarter gained $0.9-1.8 \mathrm{~kg}$ and one quarter gained $>1.8 \mathrm{~kg}$. Weight gain was correlated with dx of AN or EDNOS vs BN, lon ger LOS and lower weight at admis sion. The last study reported that pa tients with AN started at a mean BMI of 18.3 (SD 1.2) and gained 0.9 points, whereas patients with $\mathrm{BN}$ started with a mean BMI of 20.3 (SD 3.3) and gained a mean of 0.3 points. The LOS in these studies was 15.3 weeks and 13.1 weeks respectively.

One study - Total of 160 patients (ie 116 AN patients and 44 BN patients). Mean LOS was 15 weeks. For AN group the SEED in relation to others decreased from 16.5 (SD 9.7) to $15.0(\mathrm{SD} 10.7)(p=0.039)$ and SEED related to weight and shape changed from 14.6 (SD 7.8) to 13.5 (SD 9.0) $(p=0.046)$. In the BN group SEED in relation to others changed from 17.3 (SD 7.8) to 13.2 (SD 8.5) $(p=0.000)$ and SEED related to weight and shape changed from $17.6($ SD 7.0) to 13.2 (SD 8.0) ( $p=$ 0.001 ). No significant difference in effect between $\mathrm{AN}$ and $\mathrm{BN}$.

Two studies for total of 61 patients. Success defined using various gain, symptom reduction, and no AMA discharge or inpatient admission. "Success" rate was 49 and $50 \%$ in these 2 studies. $\oplus \circ \circ \circ$

VERY

LOW

(1)

CRITICAL

(1)

$\oplus \circ 00$

VERY

LOW

IMPORTANT

One study including 30 patients.

$\oplus \circ \circ \circ$ LOS was 10.5 weeks. Motivational VERY Stage of Change was measured pre- LOW

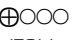

VERY

LOW

IMPORTANT post with the MSCARED. Patients were noted to progress through 1.9 $+/-1.3$ stages from beginning to end of treatment $(p<0.0001)$. The change in SOC from intake to dis charge was significantly correlated 
Table 55 Multimodal day treatment be used in the treatment of children and adolescents with eating disorders (Continued)

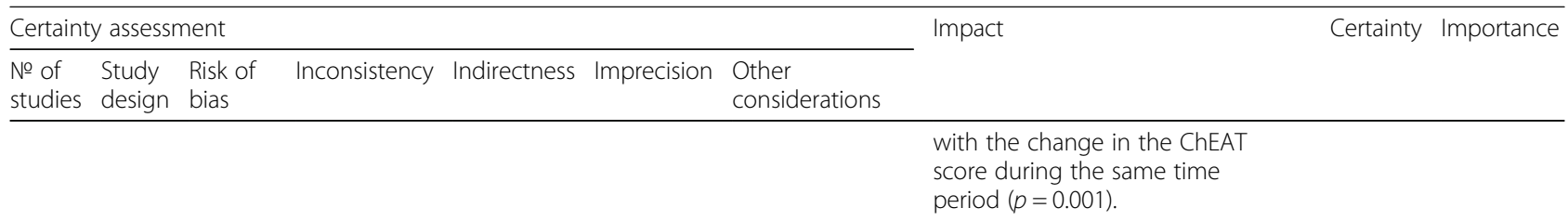

Explanations

a Observational study with no comparison/control

${ }^{\mathrm{b}}$ Confidence intervals wider than effect size

Bibliography:

Case series - Bustin 2013 [260], Lazaro 2011 [259], Dancyger 2002 [257], Dancyger 2003 [258], deGraft-Johnston 2013 [261]

One study consisting of 32 patients reported on body image disturbance [263]. Body image disturbance disappeared completely in 59\%, decreased partially in $28 \%$ and remained unchanged in 13\%. Prolonged duration of meals improved during treatment and "normalized" in $87.5 \%$ by end of treatment. Eighty-seven percent stopped ritualistic exercise habits by end of treatment.

One study including 60 patients, with median length of stay 8 months showed statistically significant change in EDI Drive for Thinness and body dissatisfaction [268]. Statistically significant change was reported on the EAT.

Mixed eating disorder diagnoses Five case series and one case report for total of 262 patients studied a family-based day treatment program with adolescents with mixed eating disorder diagnoses [272-277] (Table 57). Studies varied with regard to the form of parent involvement, hours/week in treatment and admission criteria. Four studies reported change in BMI from admission to discharge and found that BMI improved [272, 275-277] (Table 57). Three studies reported on change in \%TGW and found significant improvements [272, $274,276]$. One study reported weight change as $12 / 19$ patients reaching $100 \% \mathrm{TGW}$ at 3 months and the other $7 / 19$ reaching a mean $\% \mathrm{TGW}$ of $94 \%$ [273]. The mean LOS varied between these studies from 3.2 weeks to 28.5 weeks. (Table 57 ).

In terms of psychological symptoms, one study with total of 51 patients looked at EDE-Q scores and found improvements [276]. Two studies for a total of $82 \mathrm{pa}-$ tients reported on change in EDI [273, 275]. EDI drive for thinness subscale decreased in one study [275], and in the second study EDI scores were reported to have improved significantly on all subscales other than maturity fears by 3 months [273]. One study examining ChEAT scores, involved 56 patients, however, only 30 patients had pre-post data to analyze. The mean length of stay was 10.3 weeks [272]. ChEAT scores improved.

One study with 51 patients [276] examined a family therapy with group DBT skills training in an intensive outpatient program. Fifteen out of 36 patients (30\%) were considered not successful due to need for higher level of care, psychiatric hospitalization or left treatment against medical advice.

One study was found with eight patients and their parents [277] describing family-based treatment with CBT principles within a DTP. Statistically significant decreases were seen in all subscales of the EDE-Q and the Yale Brown Cornell Eating Disorder Scale (YBC-EDS) total score decreased significantly [277] (Table 57).

Avoidant/restrictive food intake disorder One study examined 32 patients with ARFID, compared to patients with AN $(n=68), \mathrm{BN}(n=15)$ and OSFED $(n=15)$ in the same DTP [278] (Table 58). This study reported that the reason for patients with ARFID to be admitted to their day treatment program was "acute onset of severe food restriction that results in significant weight loss or failure to gain weight." Length of stay for ARFID patients was significantly shorter than for those with AN, but not compared to those with $\mathrm{BN}$ or OSFED. Patients with ARFID gained weight from $86 \%$ median BMI to $95 \%$ median BMI which did not differ from the median weight gain for the AN or OSFED groups (Table 58). This study also reported that patients with ARFID had total ChEAT scores that were subclinical at admission and demonstrated minimal change in scores during treatment. There were no significant differences between the diagnostic groups at the end of treatment on ChEAT scores [278].

\section{Family-based day treatment combined with dialectical Behavioural therapy}

Bulimia nervosa One study including 35 adolescent females with BN examined DBT combined with FBT principles within a day hospital setting [279] (Table 59). Length of stay was 77.18 days. Binge-purge symptoms monitored via self-report on EDE-Q decreased significantly [279]. EDE-Q global, shape and weight concerns decreased significantly pre-post, whereas restraint and 
Table 56 Family-based day treatment for children and adolescents with anorexia nervosa and low-weight eating disorders

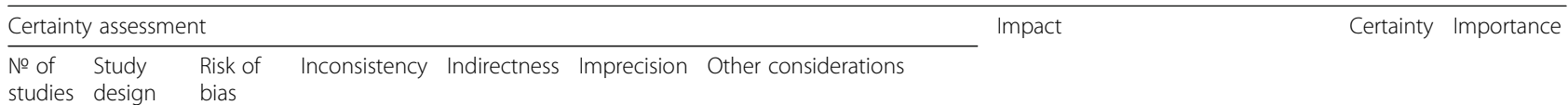

Change in Weight (assessed with: Pre-post change in weight outcomes), Change in EDE-Q scores, change in symptoms

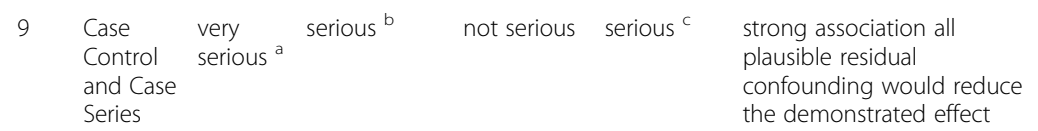

$\begin{array}{lll}\text { Nine studies for a total of } 427 & \text { POOO } & \text { CRITICAL } \\ \text { patients. Studies varied with } & \text { VERY } & \\ \text { regards to degree/method of } & \text { LOW } \\ \text { including parents in treatment, \# } & \end{array}$

Five studies reported on change in BMI which rose from 17.5 (SD

0.4 ) to 19.5 (SD 0.4), 16.4 to 19.6

$16.3(+/-1.6)$ to $17.3(+/-1.3)$,

17.01 (range 12.3-22.1) to 20.05

(range 14.8-25.1), and $16.2(+/-$

1.98) to $19.4(+/-2.87)$. Three

studies reported on total weight

gained in program $(8.6 \mathrm{~kg}+/-$

$4.5 \mathrm{~kg} ; 5.0 \mathrm{~kg} \mathrm{+/}-2.5 ; 7.3 \mathrm{~kg} \mathrm{+/-}$

3.1 and $17.58 \mathrm{~kg}$ ). Two studies

reported on change in \%TGW

which rose from 82.56 to $93.00 \%$

in one study and 82.3 to $97.99 \%$.

LOS in these studies varied from

27.6 (SD 12.13) days to 1.3 (SD

0.2 ) years. One study reported

on difference in weight

outcomes between their

Maudsley and non-Maudsley

DTP, noting no difference be

tween these 2 groups. One

other study reported on differ

ences between patients who re

ceived "formal psychotherapy"

(individual and/or family) outside

of program thereby needing to

leave program for approx $2 \mathrm{~h}$ /

week and noted that patients

who received psychotherapy

within the first 2 months of en

tering DTP gained significantly

less weight (ie $5.0+/-2.5 \mathrm{~kg}$ vs

$7.3+/-3.1 \mathrm{~kg}$ ). One study exam

ined predictors of weight restor

ation in DTP and reported that

Higher BMI at admission (range

12.3-22.1), greater gain in \%TGW

in first 4 weeks (range -0.18 to

$25.27 \%$ TGW) and lower care

giver empowerment at baseline were predictive of weight restor ation at end of intensive treat ment (ie DTP + IOP).

$\begin{array}{lll}\begin{array}{l}\text { very not serious not serious not serious } \\ \text { serious }\end{array} & \begin{array}{l}\text { all plausible residual } \\ \text { confounding would reduce } \\ \text { the demonstrated effect }\end{array}\end{array}$

Five studies receiving a familybased DTP treatment. LOS was over 11.7 weeks (patients did not attend every day as they were transitioning back to school), 27.6 days (SD 12.13) and 11.56 days (SD 6.61), and one was a 3 month follow up. Weight at onset in 4 studies were similar although reported in different 
Table 56 Family-based day treatment for children and adolescents with anorexia nervosa and low-weight eating disorders (Continued)

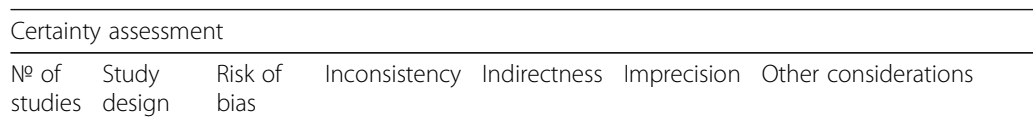

$$
\text { Impact }
$$

$\begin{array}{lll}\begin{array}{l}\text { very } \\ \text { serious e }\end{array} & \text { not serious not serious not serious } & \text { all plausible residual } \\ & \text { confounding would reduce } \\ & \text { the demonstrated effect }\end{array}$

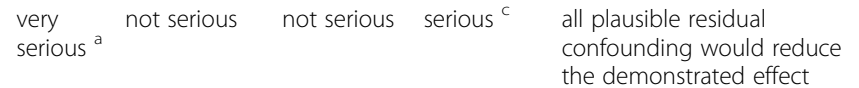

$\operatorname{lery}_{\text {serious }^{a}}$ not serious not serious serious

all plausible residual

confounding would reduce ways (ie $80.94 \%$ TGW

in first study, BMI 16.3/79.9\%

in the second study, $82.56 \%$

in third study and BMI 16.4

in forth study). EDE scores,

global and all subscales

decreased significantly in all

studies, although confidence

intervals overlapped with size

of effect. In the study

reporting on a control group

which was treated in the

same program, but without

the inclusion of Maudsley/family

interventions, the EDE-Q scores

decreased more in the Maudsley

group than the non-Maudsley

as the Maudsley group started

with higher EDE-Q scores and

at the end of the treatment

period their scores were similar

to the non-Maudsley. Of note

the scores for Wt Concern and

Restraint Concerns did not

change significantly in the

non-Maudsley group whereas

they decreased significantly

in the Maudsley group. the demonstrated effect
One study consisted of 32

patients. LOS not reported in

study. Body image disturbance

disappeared completely in

$59 \%$, decreased partially in

$28 \%$ and remained unchanged

in $13 \%$. Prolonged duration of

meals improved during

treatment and "normalized"

in $87.5 \%$ by end of treatment.

Eighty-seven percent stopped

ritualistic exercise habits by

end of treatment.

One study including 60

$\oplus \circ 0 \circ$

VERY

8 months (SD 227). Statistically LOW

significant change was reported

in EDI-3 Drive for Thinness

(53.40 +/- 35 to $30.68+$ +/-

31.70) and Dissatisfaction

$(50.88+/-27.60$ to 31.62

$+/-29.80), p<0.001$.

One study including 60

in EAT-26. Mean EAT-26 score

was $26.70(+/-17.7)$ at

admission and $7.97(+/-11.5)$

at discharge, $p<0.001$.

Explanations

${ }^{a}$ Many studies did not include a control or comparison group

${ }^{\mathrm{b}}$ Admission weight, \# hours/weeks of treatment, process of family involvement and LOS varied among studies, likely affecting outcome

${ }^{c}$ Confidence intervals wider than effect size in some studies

dOnly one study included a control comparison, no blinding of participants possible

${ }^{\mathrm{e}}$ No validated scale used, no comparison/control group

Bibliography:

Case control - Bean 2010 [264], Danziger 1989 [262]

Case series - Danziger 1988 [263], Gezelius 2016 [265], Martin-Wagar 2019 [269], Rienecke 2016 [266], Rienecke 2018 [267], Simic 2018 [270],

Zanna 2017 [268] 
Table 57 Family-based day treatment/intensive outpatient for adolescents with eating disorders (Continued)

\begin{tabular}{|c|c|c|c|c|c|c|c|c|c|}
\hline \multicolumn{7}{|c|}{ Certainty assessment } & \multirow[t]{2}{*}{ Impact } & \multirow[t]{2}{*}{ Certainty } & \multirow[t]{2}{*}{ Importance } \\
\hline $\begin{array}{l}\text { № of } \\
\text { studies }\end{array}$ & $\begin{array}{l}\text { Study } \\
\text { design }\end{array}$ & $\begin{array}{l}\text { Risk of } \\
\text { bias }\end{array}$ & Inconsistency & Indirectness & Imprecision & Other considerations & & & \\
\hline & & & & & & & $\begin{array}{l}\text { reported in study was } \\
1.6 \text { (SD 1.4). }\end{array}$ & & \\
\hline & & $\begin{array}{l}\text { very } \\
\text { serious a }\end{array}$ & not serious & not serious & serious $^{c}$ & $\begin{array}{l}\text { all plausible residual } \\
\text { confounding would reduce } \\
\text { the demonstrated effect }\end{array}$ & $\begin{array}{l}\text { Two studies for a total of } \\
82 \text { patients reported on } \\
\text { change in EDI. Admission } \\
\text { to the program } \\
\text { was determined based on } \\
\text { clinical assessment that } \\
\text { the patients required a high } \\
\text { level of treatment intensity } \\
\text { based on symptomatology, } \\
\text { in some cases patients had } \\
\text { not received any prior } \\
\text { treatment. LOS were } 15 \text { and } \\
21.4 \text { weeks. Change in EDI-2 } \\
\text { was reported in one study } \\
\text { and stated that EDI-DT } \\
\text { decreased from 16.05 } \\
\text { (SD 6.04) to 11.56 (SD 7.42) } \\
\text { and EDI-BD decreased from } \\
19.85 \text { (SD 8.39) to } 17.31 \\
\text { (SD 9.21), this study also } \\
\text { reported that of those } \\
\text { starting above the norm } \\
\text { at beginning of study, } 40 \% \\
\text { of patients improved on } \\
\text { EDI-DT and 24.6\% on EDI-BD). } \\
\text { In the second study EDI-3 } \\
\text { scores were reported to } \\
\text { have improved significantly } \\
\text { on all subscales other than } \\
\text { maturity fears by } 3 \text { months. } \\
\text { Scores for EDI-DT decreased } \\
\text { from 49.24 (SD 12.61) to } \\
42.06 \text { (SD 11.52) and EDI-BD } \\
\text { from 48.47 (SD 11.85) to } \\
46.65 \text { (SD 11.74). }\end{array}$ & $\begin{array}{l}\oplus O O O \\
\text { VERY } \\
\text { LOW }\end{array}$ & IMPORTANT \\
\hline & & $\begin{array}{l}\text { very } \\
\text { serious }^{a}\end{array}$ & not serious & not serious & serious $^{c}$ & $\begin{array}{l}\text { all plausible residual } \\
\text { confounding would reduce } \\
\text { the demonstrated effect }\end{array}$ & $\begin{array}{l}\text { One study involved } 56 \\
\text { patients, only } 30 \text { patients } \\
\text { had pre-post data to analyze, } \\
\text { mean LOS of } 10.3 \text { weeks. } \\
\text { ChEAT scores reported only } \\
\text { in graph format, all subscales } \\
\text { significantly improved, } \\
\text { although upper and lower } \\
\text { confidence intervals } \\
\text { overlapped with median } \\
\text { effect in all subcales. }\end{array}$ & $\begin{array}{l}\oplus \circ O \circ \\
\text { VERY } \\
\text { LOW }\end{array}$ & IMPORTANT \\
\hline & & $\begin{array}{l}\text { very } \\
\text { serious a }\end{array}$ & not serious & not serious & not serious & none & $\begin{array}{l}\text { Completion rate - One study } \\
\text { with } 51 \text { patients. Patients were } \\
\text { referred from both inpatient } \\
\text { and outpatient sources based } \\
\text { on severity of symptoms. } \\
15 / 36 \text { patients ( } 30 \% \text { ) were } \\
\text { considered not successful } \\
\text { (ie premature d/c) due to } \\
\text { need for higher level of care, } \\
\text { psychiatric hospitalization } \\
\text { or left treatment AMA. Mean } \\
\text { LOS was } 222 \text { (SD 3.8) days. }\end{array}$ & $\begin{array}{l}\oplus O 00 \\
\text { VERY } \\
\text { LOW }\end{array}$ & CRITICAL \\
\hline
\end{tabular}

Change in EDE, YBC-EDS (assessed with: Pre/post YBC-EDS), Body Checking Questionnaire

\begin{tabular}{|c|c|c|c|c|c|c|}
\hline $\begin{array}{l}\text { Case } \\
\text { Report }\end{array}$ & $\begin{array}{l}\text { very } \\
\text { serious }\end{array}$ & not serious & not serious & serious $^{c}$ & $\begin{array}{l}\text { all plausible residual } \\
\text { confounding would reduce } \\
\text { the demonstrated effect }\end{array}$ & $\begin{array}{l}\text { One study with } 8 \\
\text { patients and their } \\
\text { parents. LOS mean } \\
\text { of } 40 \text { days }+/-17.2 \text {. } \\
\text { Intervention was }\end{array}$ \\
\hline
\end{tabular}


Table 57 Family-based day treatment/intensive outpatient for adolescents with eating disorders (Continued)

\begin{tabular}{|c|c|c|c|c|c|c|c|c|c|}
\hline \multicolumn{7}{|c|}{ Certainty assessment } & \multirow[t]{2}{*}{ Impact } & \multirow[t]{2}{*}{ Certainty } & \multirow[t]{2}{*}{ Importance } \\
\hline $\begin{array}{l}\text { № of } \\
\text { studies }\end{array}$ & $\begin{array}{l}\text { Study } \\
\text { design }\end{array}$ & $\begin{array}{l}\text { Risk of } \\
\text { bias }\end{array}$ & Inconsistency & Indirectness & Imprecision & Other considerations & & & \\
\hline & & & & & & & $\begin{array}{l}\text { family-based with } \\
\text { CBT principles. EDE-Q } \\
\text { subscales --statistically } \\
\text { significant decreases } \\
\text { in all subscales (range } \\
p=0.012 \text { to } 0.028 \text { ). }\end{array}$ & & \\
\hline & & $\begin{array}{l}\text { very } \\
\text { serious }^{\text {a }}\end{array}$ & not serious & not serious & serious $^{c}$ & $\begin{array}{l}\text { all plausible residual } \\
\text { confounding would reduce } \\
\text { the demonstrated effect }\end{array}$ & $\begin{array}{l}\text { YBC-EDS total score } \\
\text { decreased from mean } \\
39.29(+/-8.42) \text { to } \\
17.12(+/-11.47) \\
(p=0.028), \text { Concerns } \\
\text { scores from mean of } \\
15.57 \text { to } 9.43 \text { ( } p=0.034) \\
\text { and Rituals from mean } \\
\text { of } 14.71 \text { to } 7.71(p=0.028) \text {. }\end{array}$ & $\begin{array}{l}\oplus O O O \\
\text { VERY } \\
\text { LOW }\end{array}$ & \\
\hline & & $\begin{array}{l}\text { very } \\
\text { serious a }\end{array}$ & not serious & not serious & serious $^{c}$ & $\begin{array}{l}\text { all plausible residual } \\
\text { confounding would reduce } \\
\text { the demonstrated effect }\end{array}$ & $\begin{array}{l}\text { BCQ total scores } \\
\text { decreased pre/post from } \\
59.67(+/-20.96) \text { to } 43.50 \\
(+/-15.15)(p=0.075) \text {. Scores } \\
\text { also decreased for idiosyncratic } \\
\text { checking and body dimensions } \\
\text { subscales ( } p=0.027 \text { and } 0.046)\end{array}$ & $\begin{array}{l}\oplus 000 \\
\text { VERY } \\
\text { LOW }\end{array}$ & \\
\hline
\end{tabular}

Explanations

abservational study with no control comparison

${ }^{b}$ Differences in admission BMI/\%TGW, LOS, amount of hours/week of treatment which are likely to affect outcomes

${ }^{\mathrm{C} C o n f i d e n c e ~ i n t e r v a l s ~ w i d e r ~ t h a n ~ e f f e c t ~ s i z e ~ i n ~ s o m e ~ s t u d i e s ~}$

Bibliography:

Case Series - Girz 2013 [273], Henderson 2014 [275], Johnston 2015 [276], Grewal 2014 [274], Ornstein 2012 [272]

Case Report - Iniesta Sepulveda 2017 [277]

Table 58 Family-based day treatment for children and adolescents with ARFID

\begin{tabular}{|c|c|c|c|c|c|c|c|c|c|}
\hline \multicolumn{7}{|c|}{ Certainty assessment } & \multirow[t]{2}{*}{ Impact } & \multirow[t]{2}{*}{ Certainty } & \multirow[t]{2}{*}{ Importance } \\
\hline $\begin{array}{l}\text { № of } \\
\text { studies }\end{array}$ & $\begin{array}{l}\text { Study } \\
\text { design }\end{array}$ & $\begin{array}{l}\text { Risk of } \\
\text { bias }\end{array}$ & Inconsistency & Indirectness & Imprecision & $\begin{array}{l}\text { Other } \\
\text { considerations }\end{array}$ & & & \\
\hline \multicolumn{10}{|c|}{ Change in Weight (assessed with: Pre/post \% median BMI), Change in ED symptomatology (assessed with: Pre/post ChEAT scores) } \\
\hline \multirow[t]{2}{*}{1} & $\begin{array}{l}\text { Case } \\
\text { Control }\end{array}$ & serious $^{a}$ & not serious & not serious & serious ${ }^{b}$ & none & $\begin{array}{l}\text { One study of } 32 \text { patients with ARFID, } \\
\text { compared to patients with AN ( } n=68) \text {, } \\
\text { BN }(n=15) \text { and OSFED }(n=15) \text { in the } \\
\text { same DTP. Study reported that the } \\
\text { reason for patients with ARFID to be } \\
\text { admitted to their PHP was "acute onset } \\
\text { of severe food restriction that results in } \\
\text { significant weight loss or failure to gain } \\
\text { weight." LOS for ARFID was significantly } \\
\text { lower than AN (7.03 +/- } 3.38 \text { weeks vs } \\
11.94+/-4.21 \text { weeks), but not BN or } \\
\text { OSFED. Patients with ARFID gained } \\
\text { weight from } 86.21 \% \text { MBMI (+/- } 9.96) \text { to } \\
95.45 \% \text { MBMI (+/- } 7.96) \text { which did not } \\
\text { differ from the median weight gain for } \\
\text { the AN or OSFED groups. }\end{array}$ & $\begin{array}{l}\text { 円OOO } \\
\text { VERY } \\
\text { LOW }\end{array}$ & CRITICAL \\
\hline & & serious $^{a}$ & not serious & not serious & serious $^{b}$ & none & $\begin{array}{l}\text { Patients with ARFID had Total ChEAT } \\
\text { scores that were subclinical at } \\
\text { admission and demonstrated minimal } \\
\text { change in scores during treatment. } \\
\text { There were no significant differences } \\
\text { between the diagnostic groups at the } \\
\text { end of treatment on ChEAT scores. }\end{array}$ & $\begin{array}{l}\text { ĐOOO } \\
\text { VERY } \\
\text { LOW }\end{array}$ & $\begin{array}{l}\text { NOT } \\
\text { IMPORTANT }\end{array}$ \\
\hline
\end{tabular}

\section{Explanation}

${ }^{a}$ No control or comparison with no treatment, just patients in same program with other ED diagnoses

${ }^{\mathrm{b}}$ Confidence intervals wide

Bibliography:

Case Control - Ornstein 2017 [278] 
Table 59 Family-based combined with DBT-based day treatment for children and adolescents with bulimia nervosa

\begin{tabular}{|c|c|c|c|c|c|c|c|c|c|}
\hline \multicolumn{7}{|c|}{ Certainty assessment } & \multirow[t]{2}{*}{ Impact } & \multirow[t]{2}{*}{ Certainty } & \multirow[t]{2}{*}{ Importance } \\
\hline $\begin{array}{l}\text { № of } \\
\text { studies }\end{array}$ & $\begin{array}{l}\text { Study } \\
\text { design }\end{array}$ & $\begin{array}{l}\text { Risk of } \\
\text { bias }\end{array}$ & Inconsistency & Indirectness & Imprecision & $\begin{array}{l}\text { Other } \\
\text { considerations }\end{array}$ & & & \\
\hline \multicolumn{10}{|c|}{$\begin{array}{l}\text { Weight Change (assessed with: Pre-post BMI), Change in frequency of bingeing and purging (assessed with: Pre-post frequency of binge/purge symp- } \\
\text { toms), Change in EDE-Q (assessed with: Pre-post EDE-Q) }\end{array}$} \\
\hline \multirow[t]{3}{*}{1} & $\begin{array}{l}\text { Case } \\
\text { Series }\end{array}$ & $\begin{array}{l}\text { very } \\
\text { serious }{ }^{\text {a }}\end{array}$ & not serious & not serious & not serious & none & $\begin{array}{l}\text { Study included } 35 \text { adolescent females. } \\
\text { Criteria for referral/admission to the } \\
\text { program was not reported. BMI did not } \\
\text { change. At admission mean BMI was } \\
26.3 \text { (SD 2.34) and at discharge mean } \\
\text { BMI was } 24.9 \text { (SD 2.87) (p 0.68). LOS } \\
77.18 \text { days. }\end{array}$ & $\begin{array}{l}\oplus O O O \\
\text { VERY } \\
\text { LOW }\end{array}$ & IMPORTANT \\
\hline & & $\begin{array}{l}\text { very } \\
\text { serious }\end{array}$ & not serious & not serious & serious $^{b}$ & none & $\begin{array}{l}\text { Study included } 35 \text { adolescent females. } \\
\text { LOS } 77.18 \text { days. B/P symptoms } \\
\text { monitored via self-report on EDE-Q re } \\
\text { ported as monthly frequency of these } \\
\text { symptoms. At admission the mean fre } \\
\text { quency of objective bingeing was } 4.03 \\
\text { (SD 6.69) and at discharge it was } 1.43 \\
\text { (SD 3.66) ( } p=0.04 \text { ). At admission the } \\
\text { self-reported (ie EDE-Q) mean frequency } \\
\text { of purging was } 10.82 \text { (SD 11.57) and at } \\
\text { discharge it was } 3.51 \text { (SD 2.26) } \\
(p=0.005 \text { ). }\end{array}$ & $\begin{array}{l}\oplus O O O \\
\text { VERY } \\
\text { LOW }\end{array}$ & CRITICAL \\
\hline & & $\begin{array}{l}\text { very } \\
\text { serious }^{\text {a }}\end{array}$ & not serious & not serious & not serious & none & $\begin{array}{l}\text { EDE-Q global, shape and weight } \\
\text { concerns decreased significantly } \\
\text { pre-post ( }(p 0.001-0.002) \text {. Restraint } \\
\text { and eating concerns scores were } \\
\text { unchanged at end of treatment. }\end{array}$ & $\begin{array}{l}\oplus O O O \\
\text { VERY } \\
\text { LOW }\end{array}$ & IMPORTANT \\
\hline
\end{tabular}

Explanations

${ }^{a}$ No comparison/control

bide confidence intervals, larger than actual effect

Bibliography:

Case Series - Murray 2015 [279]

eating concerns scores were unchanged at end of treatment [279].

\section{CBT- based day treatment}

Anorexia nervosa One case series including 42 patients with AN examined a CBT- based day treatment program [280] (Table 60). Length of stay in day treatment was a mean of 22.2 weeks. Patients gained weight, with a mean increase of $5.37 \mathrm{~kg}$ or BMI increase of $1.87 \mathrm{~kg} / \mathrm{m}$ over the course of treatment (Table 60). It was noted the increase in weight was correlated with the number of months in program, as well as EDI scores and Motivational Stages of Change score. Of note only 38 completed 2 months, 25 completed 4 months and 9 completed 6 months of treatment.

\section{Behaviour therapy based day treatment}

Avoidant/restrictive food intake disorder Two case reports were found describing patients aged 4 years (fear of choking) [281] and 8 years (emetophobia) [282]. Length of stay in the day treatment program was 9 days and 7 days respectively. At the end of treatment, the patients had increased their intake (Table 61). The 4 year old was no longer supplement dependent and accepting 30 new foods. The 8 year old had increased her intake from having nothing by mouth to meeting her daily nutritional needs.

\section{Resistance training as an adjunct in a day treatment program}

Mixed diagnoses This randomized controlled study involved 36 patients with mixed diagnoses of eating disorders (18 intervention and 18 control) [283]. The study took place within a day treatment program and consisted of supervised exercise (50-60 min), for 3 days per week for 8 weeks. In order to be included in the study the patients must have had a BMI greater than 14 and could not be "excessive exercisers" (ie $<6 \mathrm{~h}$ per week). Intervention patients received resistance training plus $150 \mathrm{kcal}$ extra to compensate for this activity. There was 
Table 60 CBT-based day treatment for children and adolescents with anorexia nervosa

\begin{tabular}{|c|c|c|c|c|c|c|c|c|c|}
\hline \multicolumn{7}{|c|}{ Certainty assessment } & \multirow[t]{2}{*}{ Impact } & \multirow[t]{2}{*}{ Certainty } & \multirow[t]{2}{*}{ Importance } \\
\hline $\begin{array}{l}\text { № of } \\
\text { studies }\end{array}$ & $\begin{array}{l}\text { Study } \\
\text { design }\end{array}$ & $\begin{array}{l}\text { Risk of } \\
\text { bias }\end{array}$ & Inconsistency & Indirectness & Imprecision & $\begin{array}{l}\text { Other } \\
\text { considerations }\end{array}$ & & & \\
\hline \multicolumn{10}{|c|}{ Change in Weight (assessed with: Pre/post measures of weight) } \\
\hline 1 & $\begin{array}{l}\text { Case } \\
\text { Series }\end{array}$ & serious $^{a}$ & not serious & not serious & serious $^{b}$ & none & $\begin{array}{l}\text { One study, including } 42 \text { patients. } \\
\text { Unclear reasons for patients being } \\
\text { referred to the program. Mean duration } \\
\text { of illness prior to admission to this } \\
\text { program was } 2.40 \text { years ( }(\mathrm{SD}=2.02) \text {. LOS } \\
\text { in Day Treatment was a mean of } 22.2 \\
\text { weeks (range } 0-52 \text { weeks). Patients } \\
\text { gained weight, with a mean increase of } \\
5.37 \mathrm{~kg} \text { or BMI increase of } 1.87 \mathrm{~kg} / \mathrm{m} \\
\text { over the course of treatment. It was } \\
\text { noted the increase in weight was } \\
\text { correlated with the number of months } \\
\text { in program }(0.23, p<0.01) \text {, EDI-DT (- } \\
4.90, p<0.001) \text {, EDI-BD ( }-3.56, p<0.001) \\
\text { and Motivational Stages of Change ( } 6.15 \text {, } \\
p<0.001) \text {. Of note only } 38 \text { completed } 2 \\
\text { months, } 25 \text { completed } 4 \text { months and } 9 \\
\text { completed } 6 \text { months -- unclear how } \\
\text { many were discharged due to improved } \\
\text { clinical presentation vs deterioration or } \\
\text { inability to meet program requirements. }\end{array}$ & $\begin{array}{l}\oplus O O O \\
\text { VERY } \\
\text { LOW }\end{array}$ & CRITICAL \\
\hline
\end{tabular}

\section{Explanations}

${ }^{a}$ Observational study with no comparison or control group

${ }^{\mathrm{b}}$ Confidence intervals not reported

Bibliography:

Case Series - Green 2015 [280]

no difference in weight restoration between groups (Table 62).

\section{Residential treatment}

Four case series examined residential treatment and included 1068 patients with AN, BN and EDNOS, along with two additional case reports (Table 63). One case series examined patients with AN exclusively [287]. Reasons for admission to residential treatment were not noted and all studies took place in the United
States. These studies measured change in weight in various ways. Four studies utilized BMI [284-287]. Admission mean BMI varied from 15.8 to 18.6. Discharge mean BMI varied from 17.8 to 21.3. Change in mean BMI from admission to discharge varied from 1.92 to 2.72. Two studies additionally reported on \%TGW at admission and discharge. Admission mean \%TGW were $83.4 \%$ [284] and $76.7 \%$ [287] and discharge mean \%TGW were 94.7 and $86.6 \%$ respectively.

Table 61 Behaviour therapy based day treatment for children with ARFID

\begin{tabular}{|c|c|c|c|c|c|c|c|c|c|}
\hline \multicolumn{7}{|c|}{ Certainty assessment } & \multirow[t]{2}{*}{ Impact } & \multirow[t]{2}{*}{ Certainty } & \multirow[t]{2}{*}{ Importance } \\
\hline $\begin{array}{l}\text { № of } \\
\text { studies }\end{array}$ & $\begin{array}{l}\text { Study } \\
\text { design }\end{array}$ & $\begin{array}{l}\text { Risk of } \\
\text { bias }\end{array}$ & Inconsistency & Indirectness & Imprecision & $\begin{array}{l}\text { Other } \\
\text { considerations }\end{array}$ & & & \\
\hline \multicolumn{10}{|c|}{ Change in eating behaviours/intake (assessed with: Pre/post measures of intake) } \\
\hline 2 & $\begin{array}{l}\text { Case } \\
\text { Reports }\end{array}$ & $\begin{array}{l}\text { very } \\
\text { serious a }\end{array}$ & not serious & not serious & not serious & none & $\begin{array}{l}\text { Two case reports, patients were } 4 \text { yrs. } \\
\text { (fear of choking) and } 8 \text { yrs. } \\
\text { (emetophobia). LOS in DTP were } 9 \text { days } \\
\text { and } 7 \text { days respectively. At end of } \\
\text { treatment the patients had increased } \\
\text { their intake. The } 4 \text { yo was no longer } \\
\text { supplement dependent and accepting } \\
30 \text { new foods. The } 8 \text { yo had increased } \\
\text { her intake from NPO to meeting her } \\
\text { daily nutritional needs. }\end{array}$ & $\begin{array}{l}\text { 円OO० } \\
\text { VERY } \\
\text { LOW }\end{array}$ & CRITICAL \\
\hline
\end{tabular}


Table 62 Resistance training in combination with day treatment for adolescents with eating disorders

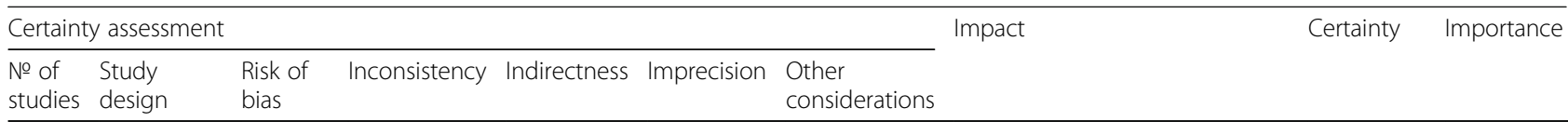

Body Mass Index at Discharge (assessed with: BMl calculated)

1 randomised serious ${ }^{a}$ not serious not serious not serious none trials

36 patients participated (18
intervention and 18 control)
another 8 patients were lost to
follow-up. Study took place
within a day treatment program
and consisted of 3 day per
week $\times 8$ weeks of supervised
exercise (50-60 min). In order to
be included in the study the
patients must have had a BMI
> 14 kg/m and could NOT be
"excessive exercisers" (ie $<6$ h
/week). Intervention patients re
ceived resistance training +150
kcal extra to compensate for
this activity. There was no dif
ference in weight restoration
between groups. Mean BMI at
initiation of study ranged was
greater than 17 in both groups
and patients had already been
hospitalized for a mean of 50.8
and 61.5 days prior to enroll
ment in the study. Exclusion
factor - excessive exercise as
part of illness.

Explanations

${ }^{a}$ No concealment or blinding for patients or study team noted Bibliography:

RCT - Fernandez-del-Valle 2016 [283]

One study reported on 361 patients that were purging at admission a mean of 3.25 times per day [284]. At discharge, they were purging a mean of 0.02 times per day. Differing diagnostic groups were not reported separately. Length of stay was an average of 52 days. Treatment was multimodal.

In terms of psychological symptoms, three studies looked at EDI scores and included 313 patients with AN, BN and EDNOS [285-287]. The treatment provided was multimodal. Length of stay varied between studies from 28.5 to 56.4 days. In general, EDI scores were improved when admission scores were compared with discharge scores. One study looked at the EDE$\mathrm{Q}$ pre to post and included 105 patients with $\mathrm{AN}$, BN and EDNOS [285]. The EDE-Q changed from 3.6 $(\mathrm{SD}=1.58)$ to $1.95(\mathrm{SD}=1.35)$.

One study including 65 patients with AN examined readiness for change. Treatment was multimodal [287]. Mean readiness for change (ANSOQC) at admission was 53.98 (SD 16.36) and at discharge was 67.28 (SD 20.06). This difference was statistically significant, but does not signify a change in actual stage of change. Participants were further divided into low readiness and high readiness. High readiness patients had a shift from 66.86 (SD 11.78) at admission to 76.80 (SD 15.71) at discharge, signifying a shift from Preparation to Action Phases. Low readiness patients shifted from 40.70 (SD 7.12) to 57.47 (SD 19.5), signifying a shift from Contemplative to Preparation Phases.

Two case reports both described patients with AN and Type 1 diabetes and reported weight gains and better glycemic control after residential treatment [288, 289]. Varying types of treatment were provided in multimodal format.

\section{Recommendations \\ Family therapy \\ Family-based treatment}

Family-based treatment (FBT) is strongly recommended for any child or adolescent with Anorexia Nervosa or Bulimia Nervosa, especially for those who have been ill less than 3 years. Strong recommendation

Qualifying statements:

There are implementation challenges with FamilyBased Treatment (FBT) including requirements for specialized, well-trained staff, access and costs of training. 
Table 63 Residential treatment for children and adolescents with eating disorders

\begin{tabular}{|c|c|c|c|c|c|c|}
\hline \multicolumn{6}{|c|}{ Certainty assessment } & \multirow[t]{2}{*}{ Impact } \\
\hline $\begin{array}{l}\text { № of } \\
\text { studies }\end{array}$ & $\begin{array}{l}\text { Study } \\
\text { design }\end{array}$ & $\begin{array}{l}\text { Risk of } \\
\text { bias }\end{array}$ & Inconsistency Indirectness & Imprecision & Other considerations & \\
\hline
\end{tabular}

$4 \quad \begin{array}{ll}\text { Case very } \\ \text { Series serious }\end{array}{ }^{\text {serious }}{ }^{b}$ not serious serious ${ }^{c, d}$ none

\begin{tabular}{|c|c|c|c|c|}
\hline $\begin{array}{l}\text { very } \\
\text { serious e }\end{array}$ & serious ${ }^{f}$ & not serious & serious $^{d}$ & $\begin{array}{l}\text { all plausible residual } \\
\text { confounding would } \\
\text { reduce the } \\
\text { demonstrated effect }\end{array}$ \\
\hline
\end{tabular}

\begin{tabular}{|c|c|c|c|}
\hline $\begin{array}{l}\text { very } \\
\text { serious } 9\end{array}$ & serious $^{b}$ & not serious & serious $^{c}$ \\
\hline
\end{tabular}

Studies included patients with AN, BN and EDNOS for a total $n=1068$. Reasons for admission to residential treatment were not noted and all studies took place in the US (ie decision for admission likely influenced by insurance coverage/ parental finances). One study noted that they included only data from the first admission for patients admitted more than once to residential treatment and that only patients who remained in treatment $>2$ weeks were included. Another study noted that patients had a mean of 1.2 previous inpatient admissions prior to residential treatment. Otherwise there was a paucity of information describing previous treatments. They measured change in weight in various ways. Four studies utilized $\mathrm{BMI}$. Admission mean BMl varied from 15.8 to 18.65. Discharge mean $\mathrm{BMI}$ varied from 17.8 to 21.3 . Change in mean BMl from admission to discharge varied from 1.92 to 2.72 . Two studies additionally reported on \%TGW at admission and discharge. Admission mean \%TGW were 83.4 and $76.7 \%$ and discharge mean \%TGW were 94.7 and $86.6 \%$ respectively.

One study reported on 361 patients that were purging at admission a mean of 3.25 times per day. At discharge they were purging a mean of 0.02 times per day. Differing diagnostic groups not reported separately. LOS 51.8 days +/- 25.8. Treatment was multimodal.

Three studies looked at EDI 3 scores and included 313 patients with AN, BN and EDNOS. Treatment provided was multimodal. Various subscales and EDI-3 Risk Composite as well as EDI-3 Global were reported in the some of the studies. EDI-3 Risk Composite was reported in 2 studies (total $n=212$ ) mean decrease in EDI-3 RC varied from 14 to 31 (SD = 23.1 and 17.62 respectively). EDI-3 Global was reported in 1 study $(n=101)$ where it decreased a mean of 39.3 points $(S D=55.2)$. EDI-3 Drive for Thinness was reported in 3 studies $(n=277)$ where it decreased a mean of 3.53, 5.11 and 12.37 (SD 6.9 7.81 and 6.42). EDI-3 was reported in 1 study $(n=111)$ and decreased 3.75 $(\mathrm{SD}=2.21)$. EDI-3 Body Dissatisfaction was reported in 1 study $\bigoplus 000$

VERY

LOW

CRITICAL

ertainty Importance $\oplus \circ \bigcirc$

VERY

LOW

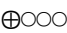

VERY

LOW

IMPORTANT 
Table 63 Residential treatment for children and adolescents with eating disorders (Continued)

\begin{tabular}{|c|c|c|c|c|c|c|c|c|c|}
\hline \multicolumn{7}{|c|}{ Certainty assessment } & \multirow[t]{2}{*}{ Impact } & \multirow[t]{2}{*}{ Certainty } & \multirow[t]{2}{*}{ Importance } \\
\hline $\begin{array}{l}\text { № of } \\
\text { studies }\end{array}$ & $\begin{array}{l}\text { Study } \\
\text { design }\end{array}$ & $\begin{array}{l}\text { Risk of } \\
\text { bias }\end{array}$ & Inconsistency & Indirectness & Imprecision & Other considerations & & & \\
\hline & & & & & & & $\begin{array}{l}(n=101) \text { where } \\
\text { it decreased } 3.45 \\
(\mathrm{SD}=10.88) . \text { LOS varied } \\
\text { between studies from } \\
28.5-56.4 \text { days, one study } \\
\text { did not report their LOS. }\end{array}$ & & \\
\hline & & $\begin{array}{l}\text { very } \\
\text { serious }{ }^{9}\end{array}$ & not serious & not serious & not serious & $\begin{array}{l}\text { all plausible residual } \\
\text { confounding would } \\
\text { reduce the } \\
\text { demonstrated effect }\end{array}$ & $\begin{array}{l}\text { One study looked at the } \\
\text { EDE-Q Pre to Post and } \\
\text { included } 105 \text { patients } \\
\text { with AN, BN and EDNOS. } \\
\text { Treatment was multimodal a } \\
\text { nd mean LOS was } 56 \text { days. } \\
\text { EDE-Q changed from } 3.6 \\
\text { (SD }=1.58 \text { ) to } 1.95 \text { (SD }=1.35 \text { ), } \\
\text { mean change }-1.56 \\
\text { (SD }=1.27 \text { ) -- similar to } \\
\text { reported norms in adolescent } \\
\text { girls. }\end{array}$ & $\begin{array}{l}\oplus O O O \\
\text { VERY } \\
\text { LOW }\end{array}$ & CRITICAL \\
\hline & & $\begin{array}{l}\text { very } \\
\text { serious c,g }\end{array}$ & not serious & not serious & not serious & $\begin{array}{l}\text { all plausible residual } \\
\text { confounding would } \\
\text { reduce the } \\
\text { demonstrated effect }\end{array}$ & $\begin{array}{l}\text { One study included } 65 \\
\text { patients with AN and } \\
\text { treatment was multimodal. } \\
\text { Mean readiness for change } \\
\text { (ANSOQC) at admission was } \\
53.98 \text { (SD 16.36) and at } \\
\text { discharge was } 67.28 \text { (SD 20.06). } \\
\text { This difference was statistically } \\
\text { significant, but signifies no } \\
\text { change in actual stage of change } \\
\text { (ie Preparation Phase scores are } \\
50-69 \text { ). They were further divided } \\
\text { into low readiness and high } \\
\text { readiness. High readiness patients } \\
\text { had a shift from } 66.86 \text { (SD 11.78) } \\
\text { at admit to } 76.80 \text { (SD 15.71) at } \\
\text { d/c, signifying a shift from } \\
\text { Preparation to Action Phases. } \\
\text { Low readiness patients shifted } \\
\text { from } 40.70 \text { (SD } 7.12 \text { ) to } 57.47 \\
\text { (SD 19.5), signifying shift from } \\
\text { Contemplative to Preparation } \\
\text { Phases. LOS was } 28.5 \text { days. }\end{array}$ & $\begin{array}{l}\oplus O O O \\
\text { VERY } \\
\text { LOW }\end{array}$ & IMPORTANT \\
\hline \multicolumn{10}{|c|}{ Weight gain } \\
\hline 2 & $\begin{array}{l}\text { Case } \\
\text { Reports }\end{array}$ & $\begin{array}{l}\text { very } \\
\text { serious }{ }^{9}\end{array}$ & not serious & not serious & not serious & none & $\begin{array}{l}\text { The } 2 \text { case reports both described } \\
\text { patients with Type } 1 \text { diabetes and } \\
\text { reported weight gains of } 2.2 \text { and } \\
4.3 \mathrm{~kg} \text { during admission. Varying } \\
\text { types of treatment provided in } \\
\text { multimodal format. LOS varied } \\
\text { among studies from } 28 \text { days to } \\
56 \text { days and in one study LOS } \\
\text { was not reported. }\end{array}$ & $\begin{array}{l}\oplus O O O \\
\text { VERY } \\
\text { LOW }\end{array}$ & IMPORTANT \\
\hline
\end{tabular}

\section{Explanations}

a Observational study with no comparison

${ }^{\mathrm{b}}$ Mixed diagnostic group (AN, BN and EDNOS)

cLarge or overlapping confidence intervals wide in some studies included here

${ }^{\mathrm{d} C o n f i d e n c e ~ i n t e r v a l s ~ n o t ~ r e p o r t e d ~ o r ~ n o t ~ r e p o r t e d ~ i n ~ a l l ~ s t u d i e s ~}$

eObservational study with no comparison, self-reported \# of purges/day

${ }^{\mathrm{f}}$ Mixed diagnostic group (AN-B/P and BN) - results not differentiated

gObservational study with no comparison, self-rated scale

Bibliography:

Case Series - Fisher 2015 [284], Weltzin 2014 [285], Twohig 2016 [286], McHugh 2007 [287]

Case Reports - Pitel 1998 [288], Rodigue 1990 [289] 
Parent-Focused Family Therapy - where the patient is seen separately from the family - may be just as effective as traditional FBT where the family is seen together. Adaptations to FBT such as shorter or longer treatment, removal of the family meal, guided self-help, parent to parent consult, short term intensive formats, and delivery of FBT by telehealth, require more study. Structural and Systemic Family therapy might be helpful for children and adolescents with Anorexia Nervosa, but the evidence generally does not indicate superiority to FBT, especially when costs are taken into consideration.

Key Evidence:

\section{Anorexia Nervosa}

One meta-analysis [21] and three high quality RCTs $[6,22,23]$ have demonstrated that greater weight gain and higher remission rates are achieved in FBT compared to individual treatment, particularly when focusing on one year follow-up. Eight large case series also show improvement in weight following treatment [26-32, 40].

\section{Bulimia Nervosa}

Three high quality RCTs for Bulimia Nervosa have been completed and compared FBT to various control conditions [48-50]. When FBT was compared to Cognitive Behavioral Therapy (CBT), remission rates were significantly higher in the FBT group (39\% versus 20\%) [50]. Remission rates were also significantly better in the FBT group, when FBT was compared to supportive psychotherapy (39\% versus 18\% ) [48]. However, when family therapy (with some elements consistent with FBT) was compared to guided self-help CBT, there were no significant differences in remission (10\% versus 14\%) [49]. A case series and case report also support the use of FBT for Bulimia Nervosa [34, 51].

\section{Multi-family therapy}

Multi-family therapy (MFT) may be a reasonable treatment option for children and adolescents with Anorexia Nervosa. Weak recommendation

Qualifying statements:

Multi-Family Therapy (MFT) provides workshops for multiple families at once and generally is delivered alongside single-family therapy following FBT principles, although some studies just report on the delivery of the multi-family workshops alone. It may be challenging for programs to run MFT as it requires several staff present for several full days and requires several families interested at the same time to begin the treatment. The delivery of MFT for children and adolescents with Bulimia Nervosa may be beneficial but requires more study. Members of the guideline committee indicated that the value of parents having support from each other cannot be understated. The panel voiced that peer support is often a missing component of treatment and hospital administration can place barriers to the implementation of this option.

\section{Key evidence:}

One large high quality RCT found that MFT (multifamily workshops plus single FBT) conferred additional benefits compared to FBT alone in terms of remission rates in adolescents with Anorexia Nervosa $(75 \%$ in MFT versus $60 \%$ in FBT) [76]. Several case series have also demonstrated a benefit of MFT [77-80]. There is one small case series examining MFT for adolescents with Bulimia Nervosa which found improvements in eating disorder symptoms [81].

\section{Additional promising therapies}

Other outpatient family therapies exist that have some data showing their promise but where more research is required before definitive recommendations can be made. These are treatment options in which research efforts should be prioritized.

They are:

- FBT for children with atypical Anorexia Nervosa.

- FBT for children with Avoidant/Restrictive Food Intake Disorder (ARFID).

- FBT for children across the gender spectrum, including individuals who are gender variant or gender non-conforming.

- Adjuncts to FBT, such as cognitive remediation therapy, art therapy and cognitive behavioural therapy for children and adolescents with Anorexia Nervosa.

- Emotion focused family therapy (EFFT) for Bulimia Nervosa and Anorexia Nervosa, as stand- alone treatment, or as an adjunct to FBT.

\section{Individual or group outpatient psychotherapies Cognitive Behavioural therapy}

Cognitive behavioural therapy may be a reasonable treatment option for children and adolescents with Anorexia Nervosa or Bulimia Nervosa. Weak recommendation

\section{Qualifying statements:}

Across the studies, Cognitive Behavioural Therapy was not offered in a uniform manner. Motivational interviewing as a component of treatment or prior to initiating treatment, may also be helpful although strong scientific evidence is lacking due to a paucity of studies.

Key evidence:

Anorexia nervosa

Eight case reports [97-104] and one large case series [96] indicate that CBT results in weight gain and improvement in eating disorder psychological symptoms for children and adolescents with Anorexia 
Nervosa. A small RCT $(n=22)$ did not show any difference between CBT and Behavioural Family Therapy in terms of these outcomes for children with Anorexia Nervosa, however, both improved [24]. Efficacy has also been shown when CBT is delivered in a group setting for Anorexia Nervosa [105, 106].

Bulimia nervosa

For Bulimia Nervosa, three high quality RCTs exist examining CBT. One RCT compared CBT to psychodynamic therapy in primarily adolescents, but also some young adults. This trial did not find any difference in terms of remission from Bulimia Nervosa. There were small advantages in terms of greater reduction in binge/ purge frequency in the CBT group [107]. There are also two high quality RCTs comparing CBT to family-based approaches for Bulimia Nervosa $[49,50]$. There are conflicting results between these two studies, with the study by Le Grange and colleagues [50] indicating significantly greater remission rates in the FBT group compared to the CBT group, whereas the study by Schmidt and colleagues [49] showed no significant difference between the groups with only a small proportion remitted in each group. Two large case series indicate significant decreases in binge/purge frequency pre to post treatment $[108,109]$. Several case reports indicating improvement in binge/purge symptoms exist [110-114].

\section{Adolescent focused psychotherapy}

Adolescent focused psychotherapy may be a reasonable treatment option for children and adolescents with Anorexia Nervosa. Weak recommendation

Qualifying statements:

Adolescent Focused Psychotherapy (AFP) could be delivered in situations in which FBT has been attempted, but been ineffective, or if FBT is contraindicated, not possible, or not available.

A manual is not yet available to clinicians, which makes training and dissemination difficult.

It is a challenge to study this type of treatment due to its lengthy nature and lack of clarity around essential elements. Adolescent Focused Psychotherapy includes elements of: an emphasis on therapeutic relationship with a goal to improve symptoms, psychoeducation, the role of the eating disorder as a coping mechanism, along with the development of more positive coping mechanisms. Panel members agreed that treatment of this nature is commonly delivered and can be quite beneficial to some patients. This treatment for Anorexia Nervosa may be beneficial, however other treatments have some advantages in terms of cost and more rapid improvement in symptoms.

Key evidence:

Anorexia Nervosa
Adolescent Focused Psychotherapy (AFP; based on psychodynamic principles) has some evidence to support its use [22, 23, 128], as does individual psychodynamic treatment [129], and group analytic psychotherapy [130]. Remission rates were not significantly different between AFP and FBT in two RCTs involving a total sample of 158 adolescents [22, 23]. Rates of $20 \%(12 / 60)$ remitted in AFP compared to 34\% (21/60) in FBT were found in the study by Lock and colleagues [23], whereas $41 \%$ in the AFP group met the weight goal of the 50th percentile in the study by Robin and colleagues [22] compared to $53 \%$ in the FBT group. Differences between FBT and AFP become more apparent at one year follow up with FBT having an advantage [23].

\section{Additional promising psychotherapies}

Other promising outpatient psychotherapies exist that require more research before definitive recommendations can be made.

These include:

- Cognitive Behavioural Therapy for Avoidant/ Restrictive Food Intake Disorder.

- Dialectical Behavioural Therapy for eating disorders.

\section{Other therapies - adjunctive yoga}

Yoga, in addition to standard treatments, may be a reasonable option for medically stable youth with Anorexia Nervosa, Bulimia Nervosa, and Other Specified Feeding and Eating Disorders. Weak recommendation

Qualifying statements:

There is no evidence to guide the specific regimen (e.g. duration, frequency) of yoga. Yoga should only be undertaken with support by the physician involved in the individual's care. Hot yoga or other strenuous forms of Yoga are not recommended when medical concerns exist. If Yoga interferes with recovery, or worsens symptoms, it should be discontinued.

\section{Key Evidence:}

One high quality study suggests some benefits in terms of the psychological symptoms of eating disorders, as well as depressive and anxious symptoms in the context of an eating disorder [136].

\section{Medications}

The clinical trials environment to test medications for the treatment of eating disorders is fraught with ethical and methodological complexity. Obtaining the required informed consent to bring a child or adolescent into a study requires disclosure of the study intent, hypotheses, and potential for side effects 
attributable to the medication. In some cases, these effects (e.g. weight gain) are connected specifically to outcomes patients may strongly fear. In addition, parents are often reluctant to give their children psychotropic medication. This often results in studies that have prolonged enrollment phases, that struggle or fail to meet recruitment goals, and suffer from high rates of patient drop out. As a consequence, study quality is poor and prone to bias.

\section{Atypical antipsychotics}

Olanzapine or aripiprazole may be reasonable treatment options for certain populations of children and adolescents with Anorexia Nervosa if monitored carefully. Weak recommendation

Qualifying statements:

In specific contexts, consideration of olanzapine and aripiprazole use may be undertaken for the adjunct treatment of low weight children and adolescents with Anorexia Nervosa. Although the evidence-base supporting these specific medications is scant and of poor quality, expert opinion suggests potential benefit in carefully selected treatment contexts. Given their propensity for side effects, these medications should only be considered with appropriate consultation and monitoring by trained specialists in Child and Adolescent Psychiatry or Pediatrics who have expertise in the treatment of children and adolescents with eating disorders. When utilized, these medications should be initiated at a very low dose $(0.625-1.25 \mathrm{mg}$ for olanzapine, or $0.5-1.0 \mathrm{mg}$ for aripiprazole) and titrated very carefully. Target doses in research trials are often modest. Informed consent from the young person, or their substitute decision maker including risk of side effects must be obtained and appropriate monitoring undertaken while these medications are in use.

Key evidence:

Olanzapine

Olanzapine has been the most commonly studied psychotropic medication for children and adolescents with Anorexia Nervosa. At present, only one small double-blind placebo-controlled trial in this population has been published [137], and no beneficial effect in favour of olanzapine was found in the 15 subjects who completed the trial. Several open trials and case series have examined the use of olanzapine in children and adolescents with Anorexia Nervosa [138142]. While some have demonstrated benefit (e.g. weight gain), reported adverse effects associated with the medication as well as patient attrition were common.

Aripiprazole
Three small poor-quality studies found aripiprazole showed some modest benefit in adolescents with Anorexia Nervosa [165-167].

\section{Additional promising medications}

The use of other medications for the purposes of eating disorder treatment require more research before definitive recommendations can be made. These medications should be a priority for research. These include:

- Selective Serotonin Reuptake Inhibitors (fluoxetine for Bulimia Nervosa).

- Risperidone and Quetiapine for use in Anorexia Nervosa.

- Atypical Antipsychotics for use in Avoidant/ Restrictive Food Intake Disorder.

- Mirtazapine use for patients with Anorexia Nervosa.

\section{Medications that are not recommended}

The medications below have no evidence to support their use in the treatment of primary eating disorder symptoms, or are harmful.

- Selective Norepinephrine Reuptake Inhibitors - no evidence.

- Mood Stabilizers - no evidence.

- Buproprion - not recommended for use in eating disorders, due to the elevated risks of seizures in this population.

Level of care - inpatient/day treatment/residential care In contrast to the above sections that examine specific treatment modalities, this section focuses on the level or setting - where care takes place. Research on level of care is generally sparse. Moreover, the setting where care takes place is often conflated with the treatment activities themselves making it difficult to attribute which mechanism(s) contributed to outcomes. Some tools already exist to guide the practitioner on which level of care might be indicated (e.g. residential, inpatient, day treatment, or outpatient care) based on a variety of clinical factors [290].

\section{Level of care}

It is strongly recommended that the least intensive treatment environment be provided (e.g. familybased treatment or day treatment versus lengthy hospitalizations) especially for those children and adolescents with Anorexia Nervosa requiring a first admission to hospital and/or with a duration of illness less than 3 years. Strong recommendation

Qualifying statements: 
Definitive clinical research does not currently exist that identifies the specific characteristics of what comprises "least intensive environment" or an agreed upon hierarchy of least to most intensive environments. However, the evidence-base does provide signals of reasonable options and areas that should be prioritized for further study. In addition, definitive clinical research does not currently exist that identifies the specific elements required to optimize inpatient, specialist outpatient, and community outpatient programs.

Key evidence:

Studies comparing different levels of care and length of stay

One trial of 167 adolescents randomized to inpatient care, a specialist outpatient program, or a generalist community outpatient program found significant improvements across all three groups with no differences between the groups [291]. In order to examine length of inpatient treatment related to outcome, two high quality studies examined the difference between patients randomized to receive a relatively short inpatient admission followed by either 20 sessions of FBT $(n=82)$ [252] or day treatment $(n=172)$ [253] compared to a lengthy inpatient stay to weight restoration. In the inpatient/FBT study [252] patients had all been unwell less than 3 years, and in the inpatient/day treatment study [253] the patients were included only if it was their first admission. At the end of FBT or day treatment, there were no significant differences between those who were discharged after a short admission versus those who remained in hospital for weight restoration in terms of: weight outcome, rate of readmissions over 12-month follow-up, or eating disorder symptoms.

Studies examining inpatient treatment only

Multiple low-quality studies have been published examining the outcomes for children and adolescents with eating disorders [187, 188, 193, 194, 197, 213, 216, 222, 224, 227, 232-234, 251, 292]. The most consistent finding is that inpatient treatment leads to weight restoration regardless of the treatment framework used. There are no studies directly comparing treatment modalities. Outcomes related to the cognitive symptoms of the eating disorder were mixed in these inpatient studies. Some low quality studies have examined various adjuncts to inpatient treatment including non-select versus selective menus, meal support, multi-family versus multi-parent group therapy, cognitive remediation therapy, and bright light therapy. Non-select menus conferred a benefit related to rate of weight restoration and meal support appeared to decrease the need for nasogastric tube feeds. Other outcomes were less evident and potentially eclipsed by the effect of the inpatient treatment milieu.

Studies examining day treatment programming only
Several low-quality studies report a benefit of day hospital programming in terms of weight restoration and reduction in eating disorder symptoms [255, 256, 258, 259, 262, 266, 272-276, 280]. Of these studies 14 described using a family-based approach [262, 264-270, 272-277], eight a multimodal approach [254-261] and one a CBT framework [280] in their programs. All studies reported an increase in mean weight during day treatment, and most studies reported improvement in eating disorder symptoms. One study compared cohorts in their program with and without family involvement [264], and found that weight outcomes did not vary with family involvement, but there was a greater improvement observed in overall symptomatology, and in particular weight concerns and dietary restraint with family involvement. Only three small studies have examined the use of day treatment settings for patients with Avoidant/ Restrictive Food Intake Disorder [278, 281, 282] and one small study examined this setting for Bulimia Nervosa [279]. One high quality study observed no harm with the addition of a standardized resistance training program to day treatment care as usual for patients with mixed eating disorder diagnoses [283].

Studies examining residential programming only

Six low quality studies examined outcomes for patients with eating disorders treated in a residential setting [284-289]. Studies included patients with Anorexia Nervosa, Bulimia Nervosa and Eating Disorder Not Otherwise Specified for a total of 1070 patients studied. Reasons for admission to residential treatment were not noted, there is a paucity of information reported on treatments received prior to admission to residential facilities, and all studies took place in the United States. Length of stay in these studies varied from 28 days to 56 days. All six studies reported that underweight patients gained weight during treatment. One study reported that episodes of purging were significantly reduced [284]. Three studies reported that eating disorder symptoms decreased significantly during treatment in the residential setting [285-287].

\section{General care considerations when choosing level or setting of treatment}

The following are reasonable care considerations as it relates to the choice of environment in which treatment is available for children and adolescents with eating disorders.

\section{Care within an inpatient treatment environment}

- Inpatient treatment may promote weight restoration regardless of model of care provided, but requires more study to determine the critical treatment elements related to weight restoration. 
- Cognitive Behavioural Therapy (CBT) and familybased inpatient treatment may lead to improvement in eating disorder symptoms.

- Inpatient treatment combined with day treatment follow-up may be helpful in weight restoration, symptom change and motivation for children and adolescents with Anorexia Nervosa.

- Adjuncts to inpatient treatment, such as nonselective menus, meal support, cognitive remediation and bright light therapy may be helpful for certain children and adolescents with eating disorders.

- Inpatient treatment alone or in combination with day treatment for Bulimia Nervosa and Avoidant/ Restrictive Food Intake Disorder requires more study.

- Peer support during inpatient treatment by other parents would be an asset.

\section{Preparing for discharge from inpatient care}

- Any transition in care is a period of high risk for deterioration and adverse events. Bridging these transitions with added supports is needed to prevent young people from suffering from adverse outcomes due to disruptions in continuity of care.

- Parental support is needed in order to prepare parents for discharge and the treatment that follows.

- Patient and parent preferences should be considered when planning for discharge.

- Issues of consent and capacity should also be considered when making decisions around admission and discharge.

\section{Care within a day treatment environment}

- Day treatment may promote weight restoration in Anorexia Nervosa regardless of model of care provided, but requires more study to determine the critical treatment elements related to weight restoration.

- Multimodal, CBT and family-based day treatment may lead to improvement in eating disorder symptoms.

- Day treatment for Avoidant/Restrictive Food Intake Disorder may be helpful in weight restoration and improved outcome.

- Resistance training may be offered to children and adolescents who do not have a history of compulsive exercise while participating in day treatment, but it remains unclear whether this intervention imparts any benefit.

- Day treatment varies significantly from study to study, so comparison is difficult. The common element appears to be a group-based treatment program with meal support.
- Equity and access to day treatment are issues to be considered. Families must live close to such a program in order to be able to attend, or must abandon their home/career to move close to a day treatment program in order for their child to attend.

\section{Care within a residential treatment program}

- Although literature was lacking to support a formal recommendation for residential treatment, many of the panel members opined that residential treatment is an essential component of treatment for some individuals with eating disorders who need lengthier treatment in a setting away from home. Based on expert opinion and those with lived experience, it was agreed that individuals who have had repeat admissions to the hospital and those with complex comorbid conditions, might benefit from residential treatment.

\section{Discussion}

These are the first Canadian Practice Guidelines to evaluate the evidence on psychotherapeutic and psychopharmacological treatments focused specifically on children and adolescents with eating disorders. Strong recommendations were supported in favour of Family-Based Treatment, and more generally in terms of least intensive treatment environment. Weak recommendations in favour of Multi-Family Therapy, Cognitive Behavioural Therapy, Adolescent Focused Psychotherapy, adjunctive Yoga, and atypical antipsychotics were confirmed. Several gaps for future work were identified including enhanced research efforts on new adjunctive treatments in order to address severe eating disorders and complex co-morbidities. Underlying the specific treatments emerged some general values and philosophies to be upheld, particularly apparent during the panel meeting. These philosophies included mutual trust and respect in the provider/patient/family relationship.

In addition, parent and patient representatives mentioned the critical importance of peer support (patient and parent), particularly in times of transition between different levels of care and from the pediatric to adult system of care. The importance of a coordinated continuum of care from outpatient to residential care was emphasized by the panel. The lack of services was also emphasized. Several individuals mentioned the lack of residential care across the country and the great need that exists for certain individuals with eating disorders for intensive inpatient and residential services. This need is particularly apparent for those who are medically stable, but have psychiatric co-morbidities and need longer term treatment in a highly structured environment. The co- 
morbidity with substance abuse was mentioned as an area where there is a complete lack of services in Canada. Patient and parent choice/preferences of treatment were also mentioned as essential to consider when thinking of the treatments and levels of care available.

The strengths of this guideline are numerous. We used rigorous methodology for our literature review and synthesis as well as for our guideline development. Our literature synthesis methods included a thorough review of all literature (including gray literature and papers of any language). We translated 25 papers for full text review. In terms of guideline development, conflict of interest statements were reviewed by an impartial chair in order to address any biases. We had a face-to-face meeting to discuss our recommendations, followed by an anonymous voting procedure. Furthermore, our panel included the voices of various stakeholder groups including researchers, clinicians, policy makers, parents and those with lived experience.

\section{Limitations}

These guidelines serve as a starting point for Canadian Practice Guidelines for treating children and adolescents with eating disorders, and as such, they have several limitations. Our guidelines did not aim to review treatments within the scope of medical stabilization, or in terms of treatments for the physical complications of eating disorders in children and adolescents. A companion Canadian Guideline focused on these topics for children and adolescents is needed. The reader is encouraged to examine the Academy for Eating Disorders Guidelines on eating disorders, and the Clinical Practice Guidelines for the $\mathrm{BC}$ eating disorders continuum of services which includes a Short Term Allocation Tool for Eating Disorders (STATED) [290], specifically outlining medical criteria for hospital admission, and level of care recommendations for the full age spectrum. None of the outpatient treatments mentioned in our current guideline should be delivered with a medically unstable child needing hospital admission for medical reasons. Similarly, if outpatient treatments are attempted, and an individual deteriorates during these treatments, or fails to progress, stepping up to either day treatment, or inpatient care may be needed. Furthermore, if outpatient treatments are not available, then lengthier inpatient stays may be necessary.

We did not examine qualitative literature in our search. The scope of our guideline was so broad already, that these studies could not be incorporated. These studies should be included in future iterations of these guidelines. Qualitative meta-syntheses on the topic of treatment for and recovery from AN in particular, highlight the importance of therapeutic alliance, treatment targets, building identity and self-acceptance [293, 294]. These qualitative works, can shed light on the concept of recovery which can have several different definitions, not just focused on symptomatic change, but quality of life, and functionality of work and relationships. For the purposes of this guideline, we focused on studies reporting on symptomatic change, however, future iterations should include other outcomes as viewed as essential to those affected by these illnesses and their families. Caregiver outcomes would also be important to include in future guidelines. We also would recommend including transition age youth as an important population with unique needs. A more in-depth examination of transitions in the health care system in general would be beneficial.

Most of the published studies to date on pharmacotherapy of eating disorders in children and adolescents have focused on the role of antipsychotic medication in AN. Despite progress in recent years, the total number of subjects studied remains small, and there is a paucity of randomized controlled trials. Further, it has become increasingly clear that there are substantive challenges involved with the completion of such studies. As a result, there is still insufficient evidence to recommend medication as a first line consideration in children and adolescents with eating disorders. Due to the significant challenges in recruitment and retention in clinical trials to date, large multi-site collaborative trials are necessary to move the field forward in determining which young patients with eating disorders might benefit most from psychotropic medication and in what fashion. In addition, we did not systematically review the literature for certain classes of medications including benzodiazepines, or stimulants. We came across a couple of case reports through searching in the other areas [295, 296], however, searches on these drugs should be included in future iterations of this guideline.

Our search strategy also had limitations. Although our search was very thorough, we were unable to retrieve several citations as full text articles. Some of these were difficult to locate as they were dissertations, conference proceedings, books, or simply did not exist. We attempted to examine sex differences, but the numbers of male subjects were so small that no conclusions could be drawn. Furthermore, although we searched the literature thoroughly for art and music therapies, we could not find any articles on these topics. In addition, two papers in the family-based therapy section were identified through external review, indicating that these papers were not found through the initial search.

Despite these limitations, these guidelines represent a significant step forward in developing a collaborative 
process for identifying effective treatments for children and adolescents with eating disorders and will be reviewed every 5 years.

\section{Future directions}

Several gaps were noted by the guideline panel and these should be a focus for future study. These gaps included treatments for complex presentations of eating disorders, including complex co-morbidity such as borderline personality disorder, obsessive compulsive disorder, and substance use disorder. Determining which treatment benefits which individual in advance should be a priority for further study. There were also difficulties in making recommendations around medication use. Studies in the area of psychopharmacology are fraught with challenges in terms of a lack of recruitment and retention. Small and poorly designed studies, make it difficult to arise at recommendations. Perhaps multi-site trials, or innovative designs are needed to further promote and enhance the evidence base where psychopharmacology is concerned. The panel noted difficulty in making recommendations on inpatient and residential levels of care, but noted that these are sorely needed services, and should be expanded in Canada, along with a more rigorous investigation of effectiveness. Developing treatments, including new and adjunctive psychotherapeutic approaches for families unable to engage in Family-Based Treatment is essential. In addition, particular populations may have unique needs that have not yet been explored, such as predominantly male populations, and those with non-binary gender identities. Furthermore, creative ways of accessing evidence-based treatment need to be explored including the use of technology to treat patients and families at a distance.

\section{Conclusions}

Our Canadian Practice Guidelines for the treatment of children and adolescents with eating disorders recommend the provision of: 1) FBT for those with $\mathrm{AN}$ or $\mathrm{BN}$ (strong recommendation), 2) MFT for those with AN (weak recommendation), 3) CBT for those with AN or BN (weak recommendation), 4) AFP for those with AN (weak recommendation), and, 5) adjunctive Yoga for those with AN, BN and OSFED (weak recommendation). All of these treatments can only be delivered in a medically stable young person, and more intensive treatment should be considered if treatments are deeming to lack efficacy. In terms of medication, a weak recommendation was confirmed for olanzapine and aripiprazole for those with AN. A strong recommendation was agreed upon for providing care in a least intensive environment. Patient and parental preferences should be considered. Research efforts should be devoted to developing treatments for severe eating disorders with complex comorbidity.

\begin{abstract}
Abbreviations
\%TGW: Percent treatment goal weight; ADHD: Attention deficit hyperactivity disorder; AFP: Adolescent focused psychotherapy; AGREE II: Appraisal of guidelines, research, and evaluation; AN: Anorexia nervosa;

ANSOCQ: Anorexia nervosa stage of change questionnaire; ARFID: Avoidant/ restrictive food intake disorder; BED: Binge eating disorder; BLT: Bright light therapy; BMI: Body mass index; BN: Bulimia nervosa; CBT: Cognitive behavioural therapy; CBT-E: Cognitive behavioural therapy - enhanced; ChEAT: Children's eating attitudes test; CRT: Cognitive remediation therapy; DBT: Dialectical behavioural therapy; DTP: Day treatment program; EAT: Eating attitudes test; EDE: Eating disorder examination; EDE-Q: Eating disorder examination - questionnaire; EDI: Eating disorders inventory; EDNOS: Eating disorder not otherwise specified; EFFT: Emotion focused family therapy; FBT: Family-based treatment; GDP: Guideline development panel; GRADE: Grading of recommendations assessment, development, and evaluation system; GUIDE-M: Guideline implementability for decision excellence model; LOS: Length of stay; MFT: Multi-family therapy; MPT: Multiparent group therapy; MSCARED: Motivational stages of change for adolescents recovering from an eating disorder; NGY: Nasogastric tube; NJ: Nasojejunum; OCD: Obsessive compulsive disorder; OSFED: Other specified feeding and eating disorder; PRISMA: Preferred reporting items for systematic reviews and meta-analyses; SNRIs: Selective norepinephrine reuptake inhibitors; SSRIs: Selective serotonin reuptake inhibitors;

TAU: Treatment as usual; YBC-EDS: Yale brown Cornell eating disorder scale
\end{abstract}

\section{Acknowledgements}

We would like to acknowledge the external reviewers of our guideline: Debra Katzman, Daniel Le Grange, James Lock, and Eric Vickar. Thank you for your expert input. We also acknowledge the following individuals for their contributions to this project - Zechen Ma, Kelsea McCready, Sadaf Sami, and Tracy Woodford. Thank you as well to all the patients and families with whom we work on a daily basis.

\section{Authors' contributions}

$J C$ conceived the idea for this project with input from MN, WS, MB, MK, GM, $C W, S F, N B$, and CM. JC was primarily responsible for the overall project design, oversight of the project and drafting of the manuscript. Several authors participated in screening abstracts and full text articles including: JC, $\mathrm{LI}, \mathrm{MN}, \mathrm{WS}, \mathrm{MK}, \mathrm{CW}, \mathrm{NS}$, and AR. Panel members who contributed to the drafting and finalization of the recommendations included: WP, CM, JC, AB, $C S, R L, T L, E W, C F, K B, J G, J G, A L, A L, J S, S G, M J, G D$, and DP. All authors read and edited the manuscript, and approved the final manuscript.

\section{Funding}

Funding for this study was provided by The Canadian Institutes for Health Research.

\section{Availability of data and materials}

Not applicable.

Ethics approval and consent to participate

Not applicable.

\section{Consent for publication}

Not applicable.

\section{Competing interests}

The authors declare that they have no competing interests.

\section{Author details}

${ }^{1}$ McMaster University, Hamilton, Canada. ${ }^{2}$ University of Ottawa, Ottawa, Canada. ${ }^{3}$ University of Toronto, Toronto, Canada. ${ }^{4}$ National Initiative for Eating Disorders, Toronto, Canada. ${ }^{5}$ Canadian Mental Health Association Waterloo, Wellington, Dufferin, Kitchener, Canada. ${ }^{6}$ The Univeristy of British Columbia, Vancouver, Canada. ${ }^{7}$ Patient advocate, Woodstock, Canada. ${ }^{8}$ Parent advocate, Woodstock, Canada. ${ }^{9}$ Ontario Ministry of Health and Long-Term Care, Toronto, Canada. ${ }^{10}$ St. Joseph's Care Group - Thunder Bay, Thunder Bay, Canada. ${ }^{11}$ Dalhousie University, Halifax, Canada. ${ }^{12}$ Laurentian 
University, Sudbury, Canada. ${ }^{13}$ McMaster Children's Hospital, Hamilton, Canada. ${ }^{14}$ University of Calgary, Calgary, Canada.

Received: 17 November 2019 Accepted: 6 January 2020

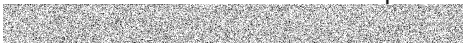

\section{References}

1. Hoek HW, van Hoeken D. Review of the prevalence and incidence of eating disorders. Int J Eat Disord. 2003:34(4):383-96.

2. Arcelus J, et al. Mortality rates in patients with anorexia nervosa and other eating disorders. A meta-analysis of 36 studies. Arch Gen Psychiatry. 2011; 68(7):724-31.

3. Ward A, et al. Follow-up mortality study of compulsorily treated patients with anorexia nervosa. Int J Eat Disord. 2015;48(7):860-5.

4. Sullivan PF. Mortality in anorexia nervosa. Am J Psychiatry. 1995;152(7):1073-4.

5. Herzog DB, Nussbaum KM, Marmor AK. Comorbidity and outcome in eating disorders. Psychiatr Clin North Am. 1996;19(4):843-59.

6. Russell GF, et al. An evaluation of family therapy in anorexia nervosa and bulimia nervosa. Arch Gen Psychiatry. 1987;44(12):1047-56.

7. Treasure J, Russell G. The case for early intervention in anorexia nervosa: theoretical exploration of maintaining factors. Br J Psychiatry. 2011;199(1):5-7.

8. Lock J, et al. Practice parameter for the assessment and treatment of children and adolescents with eating disorders. J Am Acad Child Adolesc Psychiatry. 2015:54(5):412-25.

9. National Institute of Health and Care Excellence. Eating disorders: recognition and treatment. United Kingdom: the National Institute of Health and Care Excellence; 2017.

10. Guyatt GH, et al. GRADE guidelines: a new series of articles in the Journal of Clinical Epidemiology. J Clin Epidemiol. 2011;64(4):380-2

11. Guyatt $\mathrm{GH}$, et al. GRADE: an emerging consensus on rating quality of evidence and strength of recommendations. BMJ. 2008;336(7650):924-6.

12. Jaeschke $R$, et al. Use of GRADE grid to reach decisions on clinical practice guidelines when consensus is elusive. BMJ. 2008:337:a744.

13. Brouwers MC, et al. AGREE II: advancing guideline development, reporting and evaluation in health care. CMAJ. 2010;182(18):E839-42.

14. Higgins JPT, Thomas J, Chandler J, Cumpston M, Li T, Page MJ, Welch VA, editors. Cochrane Handbook for Systematic Reviews of Interventions. 2nd ed. Chichester: Wiley; 2019.

15. Guyatt G, Rennie D. Users' guides to the medical literature: a manual for evidence-based clinical practice. Chicago: American Medical Association; 2002.

16. Brouwers $M C$, et al. Validation of the guideline implementability for decision excellence model (Guide-M). BMJ Qual Saf. 2013;22(Suppl 1):A1-A94.

17. Eccles MP, et al. Developing clinical practice guidelines: target audiences, identifying topics for guidelines, guideline group composition and functioning and conflicts of interest. Implement Sci. 2012:7:60.

18. Kunz R, et al. Guideline group composition and group processes: article 3 in Integrating and coordinating efforts in COPD guideline development. An official ATS/ERS workshop report. Proc Am Thorac Soc. 2012;9(5):229-33.

19. Qaseem A, et al. Guidelines international network: toward international standards for clinical practice guidelines. Ann Intern Med. 2012;156(7):525-31.

20. Yousuf MI. Using experts' opinion through the Delphi technique. Pract Assess Res Eval. 2007;12(4):1-8.

21. Couturier J, Kimber M, Szatmari P. Efficacy of family-based treatment for adolescents with eating disorders: a systematic review and meta-analysis. Int J Eat Disord. 2013;46(1):3-11.

22. Robin $\mathrm{AL}$, et al. A controlled comparison of family versus individual therapy for adolescents with anorexia nervosa. J Am Acad Child Adolesc Psychiatry. 1999:38(12):1482-9.

23. Lock J, et al. Randomized clinical trial comparing family-based treatment with adolescent-focused individual therapy for adolescents with anorexia nervosa. Arch Gen Psychiatry. 2010;67(10):1025-32.

24. Ball J, Mitchell P. A randomized controlled study of cognitive behavior therapy and behavioral family therapy for anorexia nervosa patients. Eat Disord. 2004;12(4):303-14.

25. Gusella JL, Campbell AG, Lalji K. A shift to placing parents in charge: does it improve weight gain in youth with anorexia? Paediatr Child Health. 2017; 22(5):269-72.

26. Paulson-Karlsson G, Engstrom I, Nevonen L. A pilot study of a family-based treatment for adolescent anorexia nervosa: 18- and 36-month follow-ups. Eat Disord. 2009;17(1):72-88.
27. Lock J, et al. Is family therapy useful for treating children with anorexia nervosa? Results of a case series. J Am Acad Child Adolesc Psychiatry. 2006; 45(11):1323-8

28. Le Grange D, Binford R, Loeb KL. Manualized family-based treatment for anorexia nervosa: a case series. J Am Acad Child Adolesc Psychiatry. 2005; 44(1):41-6.

29. Loeb KL, et al. Open trial of family-based treatment for full and partial anorexia nervosa in adolescence: evidence of successful dissemination. Am Acad Child Adolesc Psychiatry. 2007;46(7):792-800.

30. Goldstein $M$, et al. The effectiveness of family-based treatment for full and partial adolescent anorexia nervosa in an independent private practice setting: clinical outcomes. Int J Eat Disord. 2016;49(11):1023-6.

31. Couturier J, Isserlin L, Lock J. Family-based treatment for adolescents with anorexia nervosa: a dissemination study. Eat Disord. 2010;18(3):199-209.

32. Herscovici C, Bay L. Favorable outcome for anorexia nervosa patients treated in Argentina with a family approach. Eat Disord. 1996;4(1):59-66.

33. Le Grange D. Family therapy for adolescent anorexia nervosa. J Clin Psychol. 1999;55(6):727-39.

34. Le Grange D, Lock J, Dymek M. Family-based therapy for adolescents with bulimia nervosa. Am J Psychother. 2003;57(2):237-51.

35. Loeb KL, et al. Family-based treatment of a 17-year-old twin presenting with emerging anorexia nervosa: a case study using the "Maudsley method". J Clin Child Adolesc Psychol. 2009;38(1):176-83.

36. $\operatorname{Sim} L A$, et al. Family-based therapy for adolescents with anorexia nervosa. Mayo Clin Proc. 2004;79(10):1305-8.

37. Krautter T, Lock J. Treatment of adolescent anorexia nervosa using manualized family-based treatment. Clin Case Stud. 2004;3(2):107-23.

38. Aspen V, Boutelle K. Family-based treatment without a family: case report of an adolescent with anorexia nervosa. Eat Weight Disord. 2014; 19(1):119-23.

39. Matthews A, Peterson CM. Intensive family-based therapy during an acute medical admission for anorexia nervosa: a case report. Clin Case Stud. 2016; 15(4):313-25.

40. Turkiewicz $\mathrm{G}$, et al. Feasibility, acceptability, and effectiveness of familybased treatment for adolescent anorexia nervosa: an observational study conducted in Brazil. Braz J Psychiatry. 2010;32(2):169-72.

41. O'Neil J, Terry R, Connelly S. Family-based approach to anorexia nervosa. Osteopath Fam Physician. 2012:4:168-71.

42. Duvvuri $V$, et al. Differential weight restoration on olanzapine versus fluoxetine in identical twins with anorexia nervosa. Int J Eat Disord. 2012; 45(2):294-7

43. Goldstein M, Madden S, Peters L. The use of effective treatments: the case of an adolescent girl with anorexia nervosa in the context of a conversion disorder. Clin Child Psychol Psychiatry. 2013;18(2):214-23.

44. Le Grange D, Schwartz S. Family therapy for identical twins with anorexia nervosa. Eat Weight Disord. 2003;8(1):84-7.

45. Eisler I, et al. Family therapy for adolescent anorexia nervosa: the results of a controlled comparison of two family interventions. J Child Psychol Psychiatry. 2000:41(6):727-36.

46. Le Grange D, et al. Randomized clinical trial of parent-focused treatment and family-based treatment for adolescent anorexia nervosa. J Am Acad Child Adolesc Psychiatry. 2016;55(8):683-92.

47. Le Grange D, et al. Evaluation of family treatments in adolescent anorexia nervosa: a pilot study. Int J Eat Disord. 1992;12(4):347-57.

48. Le Grange D, et al. A randomized controlled comparison of family-based treatment and supportive psychotherapy for adolescent bulimia nervosa. Arch Gen Psychiatry. 2007;64(9):1049-56.

49. Schmidt $U$, et al. A randomized controlled trial of family therapy and cognitive behavior therapy guided self-care for adolescents with bulimia nervosa and related disorders. Am J Psychiatry. 2007;164(4):591-8.

50. Le Grange D, et al. Randomized clinical trial of family-based treatment and cognitive-behavioral therapy for adolescent bulimia nervosa. J Am Acad Child Adolesc Psychiatry. 2015;54(11):886-94 e2.

51. Dodge $E$, et al. Family therapy for bulimia nervosa in adolescents: an exploratory study. J Fam Ther. 1995;17:59-77.

52. Hughes EK, et al. A case series of family-based treatment for adolescents with atypical anorexia nervosa. Int J Eat Disord. 2017;50(4):424-32.

53. Spettigue $W$, et al. Treatment of children and adolescents with avoidant/restrictive food intake disorder: a case series examining the feasibility of family therapy and adjunctive treatments. J Eat Disord. 2018:6(20):1-11. 
54. Murray SB, Thornton C, Wallis A. Selective eating in a 9-year-old boy: family therapy as a first-line treatment. Clin Child Psychol Psychiatry. 2013;18(2): 270-5.

55. Strandjord SE, Ng H, Rome ES. Effects of treating gender dysphoria and anorexia nervosa in a transgender adolescent: lessons learned. Int J Eat Disord. 2015:48(7):942-5.

56. Lock J, et al. A comparison of short- and long-term family therapy for adolescent anorexia nervosa. J Am Acad Child Adolesc Psychiatry. 2005; 44(7):632-9

57. Herscovici CR, Kovalskys I, Orellana L. An exploratory evaluation of the family meal intervention for adolescent anorexia nervosa. Fam Process 2017;56(2):364-75.

58. Lock J, et al. Parental guided self-help family based treatment for adolescents with anorexia nervosa: A feasibility study. Int J Eat Disord. 2017; 50(9):1104-8.

59. Rhodes $\mathrm{P}$, et al. Can parent-to-parent consultation improve the effectiveness of the maudsley model of family-based treatment for anorexia nervosa? A randomized control trial. J Fam Ther. 2008;30:96-108.

60. Lock J, et al. Can adaptive treatment improve outcomes in family-based therapy for adolescents with anorexia nervosa? Feasibility and treatment effects of a multi-site treatment study. Behav Res Ther. 2015;73:90-5.

61. Rockwell RE, Boutelle K, Trunko ME, Joy Jacobs M, Kaye WH. An innovative short-term, intensive, family-based. treatment for adolescent anorexia nervosa: case series. Eur Eat Disord Rev. 2011;19(4):362-7.

62. Marzola E, Knatz S, Murray SB, Rockwell R, Boutelle K, Eisler I, Kaye WH. Short-term intensive family. therapy for adolescent eating disorders: 30month outcome. Eur Eat Disord Rev. 2015;23(3):210-8.

63. Goldfield GS, Boachie A. Delivery of family therapy in the treatment of anorexia nervosa using telehealth. Telemed J E Health. 2003;9(1):111-4.

64. Anderson $\mathrm{KE}$, et al. Utilizing telehealth to deliver family-based treatment for adolescent anorexia nervosa. Int J Eat Disord. 2017;50(10):1235-8.

65. Lock J, et al. Feasibility study combining art therapy or cognitive remediation therapy with family-based treatment for adolescent anorexia nervosa. Eur Eat Disord Rev. 2018;26(1):62-8.

66. Ganci M, Pradel M, Hughes EK. Feasibility of a parent education and skills workshop for improving response to family-based treatment of adolescent anorexia nervosa. Int J Eat Disord. 2018;51(4):358-62.

67. Accurso EC, et al. Adaptation and implementation of family-based treatment enhanced with dialectical behavior therapy skills for anorexia nervosa in community-based specialist clinics. Eat Disord. 2018;26(2):149-63.

68. Peterson $\mathrm{C}$, et al. FBT with adjunctive parent emotion coaching in an adolescent male with anorexia nervosa. Clin Case Stud. 2016;15(5):409-23.

69. Wagner I, et al. Attachment-based family therapy as an adjunct to familybased treatment for adolescent anorexia nervosa. Aust N Z J Fam Ther. 2016:37:207-27.

70. Hildebrandt T, et al. Exposure-based family therapy (FBT-E): An open case series of a new treatment for anorexia nervosa. Cogn Behav Pract. 2014;21: 470-84

71. Timko CA, et al. An open trial of Acceptance-based Separated Family Treatment (ASFT) for adolescents with anorexia nervosa. Behav Res Ther 2015:69:63-74.

72. Hurst K, Zimmer-Gembeck M. Family-based treatment with cognitive behavioural therapy for anorexia. Clin Psychol. 2019;23:61-70.

73. Merwin RM, Zucker NL, Timko CA. A pilot study of an acceptance-based separated family treatment for adolescent anorexia nervosa. Cogn Behav Pract. 2013;20(4):485-500

74. Hurst K, Zimmer-Gembeck M. Focus on perfectionism in female adolescent anorexia nervosa. Int J Eat Disord. 2015;48(7):936-41.

75. Hurst K, Read S, Holtham T. Bulimia nervosa in adolescents: a new therapeutic frontier. J Fam Ther. 2017;39(4):563-79.

76. Eisler I, et al. A pragmatic randomised multi-centre trial of multifamily and single family therapy for adolescent anorexia nervosa. BMC Psychiatry. 2016; 16(1):422.

77. Gabel K, et al. The effect of multiple family therapy on weight gain in adolescents with anorexia nervosa: pilot data. J Can Acad Child Adolesc Psychiatry. 2014;23(3):196-9.

78. Hollesen A, Clausen L, Rokkedal K. Multiple family therapy for adolescents with anorexia nervosa: a pilot study of eating disorder symptoms and interpersonal functioning. J Fam Ther. 2013;35:53-67.

79. Salaminiou $\mathrm{E}_{\text {, et }}$ al. Intensive multi-family therapy for adolescent anorexia nervosa: an open study of 30 families. J Fam Ther. 2017;39:498-513.
80. Gelin Z, et al. The effects of a multiple family therapy on adolescents with eating disorders: an outcome study. Fam Process. 2015;54(1):160-72.

81. Stewart C, et al. Multi-family therapy for bulimia nervosa in adolescence. Eat Disord. 2015;23(4):345-55.

82. Agras WS, et al. Comparison of 2 family therapies for adolescent anorexia nervosa: a randomized parallel trial. JAMA Psychiatry. 2014;11(11):1279-86.

83. Carr A, McDonnell D, Afnan S. Anorexia nervosa: the treatment of a male case with combined behavioural and family therapy. J Fam Ther. 1989;11: 335-51.

84. Merl H. Systemic family therapy in a case of anorexia nervosa in a boy--a case report within the scope of final interventions. Psychother Psychosom Med Psychol. 1989;39(12):444-51.

85. De Benedetta $\mathrm{G}$, et al. Cancer and anorexia nervosa in the adolescence: a family-based systemic intervention. Int J Family Med. 2011;2011:1-8.

86. Minuchin S, et al. A conceptual model of psychosomatic illness in children. Family organization and family therapy. Arch Gen Psychiatry. 1975;32(8): 1031-8.

87. Wallin $U$, Kronvall P. Anorexia nervosa in teenagers: change in family function after family therapy, at 2-year follow-up. Nord J Psychiatry. 2002; 56(5):363-9.

88. Combrinck-Graham L. Structural family therapy in psychosomatic illness. Treatment of anorexia nervosa and asthma. Clin Pediatr (Phila). 1974;13(10): 827-33.

89. Liebman R, Minuchin S, Baker L. The role of the family in the treatment of anorexia nervosa. J Am Acad Child Psychiatry. 1974;13(2):264-74.

90. Godart N, et al. A randomized controlled trial of adjunctive family therapy and treatment as usual following inpatient treatment for anorexia nervosa adolescents. PLoS One. 2012;7(1):e28249.

91. Debow SL. Identical twins concordant for anorexia nervosa. A preliminary case report. Can Psychiatr Assoc J. 1975;20(3):215-7.

92. Lane D, Kern R. Multidimensional treatment of a 14-year-old anorexia nervosa patient. J Child Adolesc Psychother. 1987:4(3):211-5.

93. O'Halloran S. Family involvement in the treatment of anorexia nervosa: A solution-focused approach. Fam J. 1999:7(4):384-8.

94. Geist R, et al. Comparison of family therapy and family group psychoeducation in adolescents with anorexia nervosa. Can J Psychiatr. 2000;45(2):173-8.

95. Johnson S, Maddeaux C, Blouin J. Emotionally focused family therapy for bulimia: Changing attachment patterns. Psychotherapy. 1998;35(2):238-47.

96. Dalle Grave $\mathrm{R}$, et al. Enhanced cognitive behaviour therapy for adolescents with anorexia nervosa: an alternative to family therapy? Behav Res Ther. 2013;51(1):R9-R12.

97. Cowdrey FA, Davis J. Response to enhanced cognitive behavioural therapy in an adolescent with anorexia nervosa. Behav Cogn Psychother. 2016;44(6): 717-22.

98. Cooper PJ, Fairburn CG. Cognitive behaviour therapy for anorexia nervosa: some preliminary findings. J Psychosom Res. 1984;28(6):493-9.

99. Martin-Murcia F, Diaz A, Gonzalez L. A case study of anorexia nervosa and obsessive personality disorder using third-generation behavioral therapies. Clin Case Stud. 2011;10(3):198-209.

100. Heffner M, Sperry J, Eifert G, Detweiler M. Acceptance and commitment therapy in the treatment of an adolescent female with anorexia nervosa: a case example. Cogn Behav Pract. 2002:9:232-6.

101. Scrignar C. Food as the reinforcer in the outpatient treatment of anorexia nervosa. J Behav Ther Exp Psychiat. 1971:2:31-6.

102. Fundudis T. Anorexia nervosa in a pre-adolescent girl: a multimodal behaviour therapy approach. J Child Psychol Psychiatry. 1986;27(2): 261-73.

103. Ollendick T. Behavioral treatment of anorexia nervosa: a five year study. Behav Modif. 1979;3(1):124-35.

104. Wildes JE, Marcus MD. Development of emotion acceptance behavior therapy for anorexia nervosa: a case series. Int J Eat Disord. 2011:44(5):421-7.

105. Pegado $P$, et al. Development, applicability, and effects of a pilot program of group cognitive-behavioral therapy in Brazilian adolescents with anorexia nervosa. Arch Clin Psychiatry. 2018;45(3):57-60.

106. Ohmann S, et al. Emotional aspects of anorexia nervosa: results of prospective naturalistic cognitive behavioral group therapy. Neuropsychiatr. 2013:27(3):119-28.

107. Stefini A, et al. Cognitive-behavioral and psychodynamic therapy in female adolescents with bulimia nervosa: a randomized controlled trial. J Am Acad Child Adolesc Psychiatry. 2017;56(4):329-35. 
108. Dalle Grave R, et al. Transdiagnostic cognitive behaivour therapy for adolescents with an eating disorder who are not underweight. Behav Res Ther. 2015;73:79-82.

109. Lock J. Adjusting cognitive behavior therapy for adolescents with bulimia nervosa: results of case series. Am J Psychother. 2005;59(3):267-81.

110. Schapman-Williams AM, Lock J, Couturier J. Cognitive-behavioral therapy for adolescents with binge eating syndromes: a case series. Int J Eat Disord. 2006;39(3):252-5.

111. Cooper $M$, et al. Cognitive therapy for bulimia nervosa: an A-B replication series. Clin Psychol Psychother. 2007;14:402-11.

112. Anbar RD, Savedoff AD. Treatment of binge eating with automatic word processing and self-hypnosis: a case report. Am J Clin Hypn. 2005;48(2-3): 191-8.

113. Schapman-Williams AM, Lock J. Using cognitive-behavioral therapy to treat adolescent-onset bulimia nervosa: a case study. Clin Case Stud. 2007;6(6): 508-24

114. Sysko R, Hildebrandt T. Enhanced cognitive behavioural therapy for an adolescent with purging disorder: a case report. Eur Eat Disord Rev. 2011; 19(1):37-45.

115. Seigel L. Classical and operant procedures in the treatment of a case of food aversion in a young child. J Clin Child Psychol. 1982;11(2):167-72.

116. Chatoor I, Conley C, Dickson L. Food refusal after an incident of choking: a posttraumatic eating disorder. J Am Acad Child Adolesc Psychiatry. 1988; 27(1):105-10.

117. Culbert TP, et al. Hypnobehavioral approaches for school-age children with dysphagia and food aversion: a case series. J Dev Behav Pediatr. 1996;17(5): 335-41.

118. Chorpita BF, Vitali AE, Barlow DH. Behavioral treatment of choking phobia in an adolescent: an experimental analysis. J Behav Ther Exp Psychiatry. 1997; 28(4):307-15.

119. Nock MK. A multiple-baseline evaluation of the treatment of food phobia in a young boy. J Behav Ther Exp Psychiatry. 2002;33(3-4):217-25.

120. Bailly D, et al. Choking phobia in childhood: a differential diagnosis with anorexia nervosa. Arch Pediatr. 2003;10(4):337-9.

121. Ciyiltepe M, Turkbay T. Phagophobia: a case report. Turk J Pediatr. 2006; 48(1):80-4.

122. Okada A, et al. A study of psycho-pathology and treatment of children with phagophobia. Acta Med Okayama. 2007;61(5):261-9.

123. de Roos C, de Jongh A. EMDR treatment of children and adolescents with a choking phobia. J EMDR Pract Res. 2008;2(1):201-11.

124. Fischer A, Luiselli J, Dove M. Effects of clinic and in-home treatment on consumption and feeding-associatied anxiety in an adolescent with avoidant/restictive food intake disorder. Clin Pract Pediatr Psychol. 2015;3(2): 154-66.

125. Murphy J, Zlomke K. A behavioral parent-training intervention for a child with avoidant/restrictive food intake disorder. Clin Pract Pediatr Psychol. 2016:4(1):23-34.

126. Reid DB. A case study of hypnosis for phagophobia: it's no choking matter Am J Clin Hypn. 2016;58(4):357-67.

127. Bloomfield B, et al. Treatment of food selectivity in a child with avoidant/ restrictive food intake disorder through parent teleconsultation. Bahav Anal Prac. 2018;12:33

128. Fitzpatrick K, et al. Adolescent focused psychotherapy for adolescents with anorexia nervosa. J Contemp Psychother. 2010;40:31-9.

129. Pharis M, Penn M. A model for outpatient treatment of young adolescents with anorexia nervosa. Child Adolesc Soc Work. 1984;1:34-48.

130. Prestano $C$, et al. Group analytic therapy for eating disorders: preliminary results in a single-group study. Eur Eat Disord Rev. 2008;16(4):302-10.

131. Fischer S, Peterson C. Dialectical behavior therapy for adolescent binge eating, purging, suicidal behavior, and non-suicidal self-injury: a pilot study. Psychotherapy (Chic). 2015;52(1):78-92.

132. Safer D, Lock J, Couturier J. Dialectical behavior therapy modified for adolescent binge eating disorder: a case report. Cogn Behav Pract. 2007;14:157-67.

133. Salbach-Andrae $H$, et al. Dialectical behavior therapy of anorexia and bulimia nervosa among adolescents: a case series. Cogn Behav Pract. 2008; 15(4):415-25.

134. Dahlgren $\mathrm{CL}$, et al. Neuropsychological functioning in adolescents with anorexia nervosa before and after cognitive remediation therapy: a feasibility trial. Int J Eat Disord. 2013;46(6):576-81.

135. van Noort BM, et al. Cognitive remediation therapy for children with anorexia nervosa. Z Kinder Jugendpsychiatr Psychother. 2015;43(5):351-5.
136. Carei TR, et al. Randomized controlled clinical trial of yoga in the treatment of eating disorders. J Adolesc Health. 2010;46(4):346-51.

137. Kafantaris $V$, et al. A placebo-controlled pilot study of adjunctive olanzapine for adolescents with anorexia nervosa. J Child Adolesc Psychopharmacol. 2011;21(3):207-12.

138. Spettigue W, et al. Evaluation of the effectiveness and safety of olanzapine as an adjunctive treatment for anorexia nervosa in adolescents: an openlabel trial. J Can Acad Child Adolesc Psychiatry. 2018;27(3):197-208.

139. Norris ML, et al. Olanzapine use for the adjunctive treatment of adolescents with anorexia nervosa. J Child Adolesc Psychopharmacol. 2011;21(3):213-20.

140. Hillebrand JJ, et al. Olanzapine reduces physical activity in rats exposed to activity-based anorexia: possible implications for treatment of anorexia nervosa? Biol Psychiatry. 2005;58(8):651-7.

141. Swenne I, Rosling A. No unexpected adverse events and biochemical side effects of olanzapine as adjunct treatment in adolescent girls with eating disorders. J Child Adolesc Psychopharmacol. 2011;21(3):221-7.

142. Leggero $C$, et al. Low-dose olanzapine monotherapy in girls with anorexia nervosa, restricting subtype: focus on hyperactivity. J Child Adolesc Psychopharmacol. 2010;20(2):127-33.

143. Pisano $S$, et al. Second generation antipsychotics in adolescent anorexia nervosa: a new hypothesis of eligibility criteria. J Child Adolesc Psychopharmacol. 2014;24(5):293-5.

144. Dennis K, Le Grange D, Bremer J. Olanzapine use in adolescent anorexia nervosa. Eat Weight Disord. 2006;11(2):e53-6.

145. Boachie A, Goldfield GS, Spettigue W. Olanzapine use as an adjunctive treatment for hospitalized children with anorexia nervosa: case reports. Int J Eat Disord. 2003;33(1):98-103.

146. Mehler $C$, et al. Olanzapine in children and adolescents with chronic anorexia nervosa. A study of five cases. Eur Child Adolesc Psychiatry. 2001; 10(2):151-7.

147. La Via MC, Gray N, Kaye WH. Case reports of olanzapine treatment of anorexia nervosa. Int J Eat Disord. 2000;27(3):363-6.

148. Dadic-Hero $E$, et al. Olanzapine treatment in anorexia nervosa: case report. Psychiatr Danub. 2009;21(1):122-5.

149. Hein IM, Huyser C. Olanzapine in the treatment of adolescents with anorexia nervosa. Tijdschr Psychiatr. 2010;52(6):417-21.

150. Tateno $M$, et al. Successful olanzapine treatment of anorexia nervosa in a girl with pervasive developmental disorder not otherwise specified. Psychiatry Clin Neurosci. 2008;62(6):752.

151. Ercan ES, et al. Olanzapine treatment of an adolescent girl with anorexia nervosa. Hum Psychopharmacol. 2003;18(5):401-3.

152. Dodig-Curkovic K, et al. The case report of treatment strategy for anorexia nervosa with psychotic elements in adolescent. Coll Antropol. 2010;34(3): 1093-9.

153. Ayyildiz $\mathrm{H}$, et al. Olanzapine-induced atypical neuroleptic malignant syndrome in an adolescent man with anorexia nervosa. Eat Weight Disord. 2016:21(2):309-11.

154. Ritchie B, Norris ML. QTc prolongation associated with atypical antipsychotic use in the treatment of adolescent-onset anorexia nervosa. J Can Acad Child Adolesc Psychiatry. 2009;18(1):60-3.

155. Norris $M L$, et al. Factors influencing research drug trials in adolescents with anorexia nervosa. Eat Disord. 2010;18(3):210-7.

156. Bozabali O, Baykara B, Baykara A. Olanzapine use in five different psychiatric disorders in children and adolescents. Bull Clin Psychopharmacol. 2002; 12(4):179-85.

157. Brewerton TD, D'Agostino M. Adjunctive use of olanzapine in the treatment of avoidant restrictive food intake disorder in children and adolescents in an eating disorders program. J Child Adolesc Psychopharmacol. 2017;27(10): 920-2.

158. Hagman J, et al. A double-blind, placebo-controlled study of risperidone for the treatment of adolescents and young adults with anorexia nervosa: a pilot study. J Am Acad Child Adolesc Psychiatry. 2011;50(9):915-24.

159. Fisman S, et al. Case study: anorexia nervosa and autistic disorder in an adolescent girl. J Am Acad Child Adolesc Psychiatry. 1996;35(7):937-40.

160. Kracke EJ, Tosh AK. Treatment of anorexia nervosa with long-term risperidone in an outpatient setting: case study. Springerplus. 2014;3:706.

161. Umehara $\mathrm{H}$, Iga J, Ohmori T. Successful treatment of anorexia nervosa in a 10-year-old boy with risperidone long-acting injection. Clin Psychopharmacol Neurosci. 2014;12(1):65-6.

162. Newman-Toker J. Risperidone in anorexia nervosa. J Am Acad Child Adolesc Psychiatry. 2000;39(8):941-2. 
163. Pennell A, et al. Severe avoidant/restrictive food intake disorder and coexisting stimulant treated attention deficit hyperactivity disorder. Int J Eat Disord. 2016;49(11):1036-9.

164. Mehler-Wex C, et al. Atypical antipsychotics in severe anorexia nervosa in children and adolescents--Review and case reports. Eur Eat Disord Rev. 2008;16(2):100-8.

165. Frank GK, et al. The partial dopamine D2 receptor agonist aripiprazole is associated with weight gain in adolescent anorexia nervosa. Int J Eat Disord. 2017:50(4):447-50.

166. Frank GK. Aripiprazole, a partial dopamine agonist to improve adolescent anorexia nervosa-a case series. Int J Eat Disord. 2016:49(5):529-33.

167. Trunko ME, et al. Aripiprazole in anorexia nervosa and low-weight bulimia nervosa: case reports. Int J Eat Disord. 2011:44(3):269-75.

168. Colak Sivri R, Hizarcioglu Gulsen H, Yilmaz A. Phagophobia successfully treated with low-dose aripiprazole in an adolescent: a case report. Clin Neuropharmacol. 2018;41(4):148-50

169. Holtkamp K, et al. A retrospective study of SSRI treatment in adolescent anorexia nervosa: insufficient evidence for efficacy. J Psychiatr Res. 2005; 39(3):303-10.

170. Frank GK, Kaye WH, Marcus MD. Sertraline in underweight binge eating/ purging-type eating disorders: five case reports. Int J Eat Disord. 2001;29(4): 495-8.

171. Lyles B, Sarkis E, Kemph JP. Fluoxetine and anorexia. J Am Acad Child Adolesc Psychiatry. 1990;29(6):984-5.

172. Gee RL, Telew N. Obsessive-compulsive disorder and anorexia nervosa in a high school athlete: a case report. J Athl Train. 1999;34(4):375-8.

173. Kotler $L A$, et al. An open trial of fluoxetine for adolescents with bulimia nervosa. J Child Adolesc Psychopharmacol. 2003;13(3):329-35.

174. Tor PC, Lee EL. Treatment emergent mania responding to valproate in a Chinese female adolescent population with eating disorders: a case series. Eur Eat Disord Rev. 2008;16(6):421-6.

175. Wolter $\mathrm{H}$, et al. Diagnostic crossover from obesity to atypical anorexia nervosa - a case report. Obes Facts. 2009;2(1):52-3.

176. Banerjee SP, Bhandari RP, Rosenberg DR. Use of low-dose selective serotonin reuptake inhibitors for severe, refractory choking phobia in childhood. J Dev Behav Pediatr. 2005;26(2):123-7.

177. Hosoglu E, Akca OF. Escitalopram in the treatment of a 3-year-old child with posttraumatic feeding disorder. J Child Adolesc Psychopharmacol. 2018; 28(2):153-4

178. Celik G, et al. Fluoxetine in posttraumatic eating disorder in two-year-old twins. J Child Adolesc Psychopharmacol. 2007;17(2):233-6.

179. Hrdlicka M, et al. Mirtazapine in the treatment of adolescent anorexia nervosa. Case-control study. Eur Child Adolesc Psychiatry. 2008;17(3):187-9.

180. Jaafar NR, et al. Mirtazapine for anorexia nervosa with depression. Aust N Z J Psychiatry. 2007:41(9):768-9.

181. Naguy A, Al-Mutairi A. An adolescent male with anorexia nervosa favorably responded to mirtazapine. Am J Ther. 2018;25(6):e675-6.

182. Gray E, et al. Mirtazapine and weight gain in avoidant and restrictive food intake disorder. J Am Acad Child Adolesc Psychiatry. 2018;57(4):288-9.

183. Tanidir C, Herguner S. Mirtazapine for choking phobia: report of a pediatric case. J Child Adolesc Psychopharmacol. 2015;25(8):659-60.

184. Anis N, Isomaa R, Kaltiala-Heino R. Adolescent psychiatric inpatients with first hospitalization due to anorexia nervosa: can rehospitalization be predcited by clinical features. Psychiatr Fenn. 2016;47:76-94

185. Ayton A, Keen C, Lask B. Pros and cons of using the mental health act for severe eating disorders in adolescents. Eur Eat Disord Rev. 2009;17(1):14-23.

186. Castro-Fornieles J, et al. Predictors of weight maintenance after hospital discharge in adolescent anorexia nervosa. Int J Eat Disord. 2007;40(2):129-35.

187. Fennig S, et al. Inpatient treatment has no impact on the core thoughts and perceptions in adolescents with anorexia nervosa. Early Interv Psychiatry. 2017;11(3):200-7.

188. Goddard E, et al. A multi-centre cohort study of short term outcomes of hospital treatment for anorexia nervosa in the UK. BMC Psychiatry. 2013;13:287.

189. Heinberg $L$, et al. Clinical course and short-term outcome of hospitalized adolescents with eating disorders: the success of combining adolescents and adults on an eating disorders unit. Eat Weight Disord. 2003;8(4):326-31.

190. Kalisvaart $\lrcorner$, Hergenroeder AC. Hospitalization of patients with eating disorders on adolescent medical units is threatened by current reimbursement systems. Int J Adolesc Med Health. 2007;19(2):155-65.

191. Leon GR, et al. Sexual, body-image, and personality attitudes in anorexia nervosa. J Abnorm Child Psychol. 1985;13(2):245-57.
192. Lievers LS, Curt F, Wallier J, Perdereau F, Rein Z, Jeammet P, Godart N. Predictive factors of length of inpatient treatment in anorexia nervosa. Eur Child Adolesc Psychiatry. 2009;18(2):75-84.

193. Mekori E, et al. Predictors of short-term outcome variables in hospitalised female adolescents with eating disorders. Int J Psychiatry Clin Pract. 2017; 21(1):41-9.

194. Morris J, Simpson AV, Voy SJ. Length of stay of inpatients with eating disorders. Clin Psychol Psychother. 2015;22(1):45-53.

195. Nova E, Lopez-Vidriero I, Varela P, Casas J, Marcos A. Evolution of serum biochemical indicators in anorexia nervosa patients: a 1-year follow-up study. J Hum Nutr Diet. 2007;21:23-30.

196. Roux $\mathrm{H}$, et al. Predictive factors of dropout from inpatient treatment for anorexia nervosa. BMC Psychiatry. 2016;16(1):339.

197. Schlegl S, et al. Inpatient treatment for adolescents with anorexia nervosa: clinical significance and predictors of treatment outcome. Eur Eat Disord Rev. 2016;24(3):214-22

198. Shugar G, Krueger S. Aggressive family communication, weight-gain, and improved eating attitudes during systemic family-therapy for anorexianervosa. Int J Eat Disord. 1995;17(1):23-31.

199. Tasaka K, et al. Long-term follow up of hospitalized pediatric anorexia nervosa restricting type. Pediatr Int. 2017;59(4):482-9.

200. Treat TA, et al. Treatment of anorexia nervosa in a specialty care continuum. Int J Eat Disord. 2008:41(6):564-72.

201. Vall E, Wade TD. Predictors and moderators of outcomes and readmission for adolescent inpatients with anorexia nervosa: a pilot study. Clin Psychol. 2017;21(2):143-52

202. Bourion-Bedes S, et al. Prognostic value of early therapeutic alliance in weight recovery: a prospective cohort of 108 adolescents with anorexia nervosa. J Adolesc Health. 2013;52(3):344-50.

203. Rothschild-Yakar L, Lacoua L, Stein D. Changes in patient measures as predictors of therapists' ratings of treatment collaboration and change in eating disorder subgroups. Assessment. 2013;20(6):752-63.

204. Toms DA, Crisp AH. Weight phobia in an adolescent male with stunted development. J Psychosom Res. 1972;16(4):289-95.

205. Strik Lievers L, Curt F, Wallier J, Perdereau F, Rein Z, Jeammet P, Godart N. Predictive factors of length of inpatient treatment in anorexia nervosa. Eur Child Adolesc Psychiatry. 2009;18(2):75-84.

206. Avnon A, et al. Inpatient weight curve trajectory as a prognostic factor among adolescents with anorexia nervosa: a preliminary report. Eat Weight Disord. 2018;23(5):645-51.

207. Hetman I, et al. Percentage from target weight (PFTW) predicts rehospitalization in adolescent anorexia nervosa. Isr J Psychiatry Relat Sci. 2017;54(3):28-34.

208. Singer $L$, et al. Cognitive-behavioural treatment of health-impairing food phobias in children. J Am Acad Child Adolesc Psychiatry. 1992;31(5):847-52.

209. Pitt PD, Middleman AB. A focus on behavior management of avoidant/ restrictive food intake disorder (ARFID): a case series. Clin Pediatr (Phila). 2018;57(4):478-80

210. Rhodes P, Prunty M, Madden S. Life-Threatening Food Refusal in Two NineYear-Old Girls: Re-Thinking the Maudsley Model. Clin Child Psychol Psychiatry. 2009;14(1):63-70.

211. Halvorsen I, et al. Naturalistic outcome of family-based inpatient treatment for adolescents with anorexia nervosa. Eur Eat Disord Rev. 2018;26(2):141-5.

212. Paul P, Mehta S, Coffey BJ. Anorexia nervosa in a 14-year-old secondgeneration hispanic adolescent boy. J Child Adolesc Psychopharmacol. 2013;23(4):295-9.

213. Salbach-Andrae $H$, et al. Short-term outcome of anorexia nervosa in adolescents after inpatient treatment: a prospective study. Eur Child Adolesc Psychiatry. 2009;18(11):701-4.

214. Leitenberg $H$, Agras WS, Thomson LE. A sequential analysis of the effect of selective positive reinforcement in modifying anorexia nervosa. Behav Res Ther. 1968;6(2):211-8.

215. Blinder BJ, Freeman DM, Stunkard AJ. Behavior therapy of anorexia nervosa: effectiveness of activity as a reinforcer of weight gain. Am J Psychiatry. 1970;126(8):1093-8.

216. Garfinkel PE, Kline SA, Stancer HC. Treatment of anorexia nervosa using operant conditioning techniques. J Nerv Ment Dis. 1973;157(6):428-33.

217. Halmi KA, Powers $P$, Cunningham S. Treatment of anorexia nervosa with behavior modification. Effectiveness of formula feeding and isolation. Arch Gen Psychiatry. 1975;32(1):93-6. 
218. Pertschuk M, Edwards N, Pomerleau O. A multiple-baseline approach to behavioural intervention in anorexia nervosa. Behav Ther. 1978;9:368-76.

219. Poole AD, Sanson-Fisher RW, Young P. A behavioural programme for the management of anorexia nervosa. Aust N Z J Psychiatry. 1978;12(1):49-53.

220. Clark DB, Munford PR. Behavioral consultation to pediatrics. Child Behavior Therapy. 1981;2(3):25-33.

221. Cinciripini PM, et al. A behavioral program for the management of anorexia and bulimia. J Nerv Ment Dis. 1983;171(3):186-9.

222. Collins M, Hodas GR, Liebman R. Interdisciplinary model for the inpatient treatment of adolescents with anorexia nervosa. J Adolesc Health Care. 1983;4(1):3-8

223. Boey KW. The restoration of body weight in anorexia nervosa through operant conditioning: a case report. Singap Med J. 1985;26(2):187-91.

224. Steinhausen HC. Evaluation of inpatient treatment of adolescent anorexic patients. J Psychiatr Res. 1985;19(2-3):371-5.

225. Alessi NE, et al. Prepubertal anorexia nervosa and major depressive disorder. J Am Acad Child Adolesc Psychiatry. 1989;28(3):380-4.

226. Nygaard JA. Anorexia nervosa. Treatment and triggering factors. Acta Psychiatr Scand Suppl. 1990;361:44-9.

227. Solanto MV, et al. Rate of weight gain of inpatients with anorexia nervosa under two behavioral contracts. Pediatrics. 1994:93(6 Pt 1):989-91.

228. Blanchet-Collet $\mathrm{C}$, et al. Anorexia nervosa hyperactivity-induced ischemic colitis (ANHIC): a new cause of anaemia. Eat Weight Disord Stud Anorexia Bulimia Obes. 2016;21(3):507-10.

229. Wockel $\mathrm{L}$, et al. Serotonin-induced decrease of intracellular $\mathrm{Ca}(2+)$ release in platelets of bulimic patients normalizes during treatment. J Neural Transm (Vienna). 2009;116(1):89-95.

230. Groen JJ, Feldman-Toledano Z. Educative treatment of patients and parentsin anorexia nervosa. Br J Psychiatry. 1966;112(488):671-81.

231. Kronenberg J, et al. The treatment of anorexia-nervosa in a general-hospital - a case vignette of a multidisciplinary general hospital-based approach. J Adolesc. 1994;17(2):163-71.

232. Maxmen JS, Siberfarb PM, Ferrell RB. Anorexia nervosa. Practical initial management in a general hospital. JAMA. 1974;229(7):801-3.

233. Jenkins ME. An outcome study of anorexia nervosa in an adolescent unit. Adolesc. 1987:10(1):71-81.

234. Lock J, Litt I. What predicts maintenance of weight for adolescents medically hospitalized for anorexia nervosa? Eat Disord. 2003;11(1):1-7.

235. Meilleur D, et al. Sociodemographic, clinical, psychological and behavioral characteristics of children 8-12 years old hospitalized for an eating disorder. J Adolesc Health. 2012;50(2):S42.

236. Depestele $L$, et al. An adjunctive multi-family group intervention with or without patient participation during an inpatient treatment for adolescents with an eating disorder: a pilot study. Eur Eat Disord Rev. 2017;25(6):570-8.

237. Salbach $\mathrm{H}$, et al. Family-oriented group therapy in the treatment of female patients with anorexia and bulimia nervosa--a pilot study. Z Kinder Jugendpsychiatr Psychother. 2006;34(4):267-74.

238. Couturier J, Mahmood A. Meal support therapy reduces the use of nasogastric feeding for adolescents hospitalized with anorexia nervosa. Eat Disord. 2009;17(4):327-32.

239. Kells $M$, et al. Examining supervised meals in patients with restrictive eating disorders. Appl Nurs Res. 2013;26(2):76-9.

240. Kells $M$, et al. Meal supervision during medical hospitalization for eating disorders. Clin Nurs Res. 2017;26(4):525-37.

241. Leacy KA, Cane JN. Effect of non-select menus on weight and eating concern in adolescents hospitalized with anorexia nervosa. Eat Disord. 2012; 20(2):159-67.

242. Janas-Kozik M, et al. Bright light treatment of depressive symptoms in patients with restrictive type of anorexia nervosa. J Affect Disord. 2011; 130(3):462-5.

243. Asch M, et al. Cognitive remediation therapy for children and adolescents with anorexia nervosa in France: an exploratory study. Encephale. 2014; 40(3):240-6

244. Herbrich $L$, et al. Follow-up assessment of cognitive remediation therapy in adolescent anorexia nervosa: a pilot study. Eur Eat Disord Rev. 2017;25(2):104-13.

245. Kuge $\mathrm{R}$, et al. Group cognitive remediation therapy for younger adolescents with anorexia nervosa: a feasibility study in a Japanese sample. BMC Res Notes. 2017;10(1):317.

246. Harrison A, et al. Cognitive remediation therapy for adolescent inpatients with severe and complex anorexia nervosa: a treatment trial. Eur Eat Disord Rev. 2018;26(3):230-40.
247. Cwojdzinska A, Markowska-Regulska K, Rybakowski F. Cognitive remediation therapy in adolescent anorexia nervosa--case report. Psychiatr Pol. 2009; 43(1):115-24.

248. Strober $M$, et al. Are there gender differences in core symptoms, temperament, and short-term prospective outcome in anorexia nervosa? Int J Eat Disord. 2006;39(7):570-5.

249. Dalle Grave R, et al. Inpatient cognitive behavior therapy for adolecents with anorexia nervosa: immediate and long-term effects. Front Psychiatry. 2014;5:14.

250. El Ghoch $M$, et al. Regional fat distribution in adolescent and adult females with anorexia nervosa: a longitudinal study. Clin Nutr. 2015; 34:1224-32.

251. Hillen S, et al. Motivation to change and perceptions of the admission process with respect to outcome in adolescent anorexia nervosa. BMC Psychiatry. 2015;15:140.

252. Madden S, et al. A randomized controlled trial of in-patient treatment for anorexia nervosa in medically unstable adolescents. Psychol Med. 2015; 45(2):415-27.

253. Herpertz-Dahlmann B, et al. Day-patient treatment after short inpatient care versus continued inpatient treatment in adolescents with anorexia nervosa (ANDI): a multicentre, randomised, open-label, non-inferiority trial. Lancet. 2014;383(9924):1222-9.

254. Garner D, Magana C. Anorexia nervosa, in clinical behavior therapy: adults and children, M. Hersen, Editor. New York: Wiley; 2002.

255. Goldstein $M$, et al. The effectiveness of a day program for the treatment of adolescent anorexia nervosa. Int J Eat Disord. 2011;44(1):29-38.

256. Ngo M, Isserlin L. Body weight as a prognostic factor for day hospital success in adolescents with anorexia nervosa. Eat Disord. 2014;22(1):62-71.

257. Dancyger I, et al. Cultural factors in orthodox Jewish adolescents treated in a day program for eating disorders. Int J Adolesc Med Health. 2002;14(4):317-28.

258. Dancyger I, et al. Adolescents and eating disorders: an examination of a day treatment program. Eat Weight Disord. 2003;8(3):242-8.

259. Lazaro $L$, et al. Effectiveness of self-esteem and social skills group therapy in adolescent eating disorder patients attending a day hospital treatment programme. Eur Eat Disord Rev. 2011;19(5):398-406.

260. Bustin LA, et al. Motivational stage of change in young patients undergoing day treatment for eating disorders. Int J Adolesc Med Health. 2013;25(2):151-6.

261. de Graft-Johnson A, et al. Weight gain in an eating disorders day program. Int J Adolesc Med Health. 2013;25(2):177-80.

262. Danziger $Y$, et al. Is psychotherapy mandatory during the acute refeeding period in the treatment of anorexia nervosa? J Adolesc Health Care. 1989; 10(4):328-31.

263. Danziger $Y$, et al. Parental involvement in treatment of patients with anorexia nervosa in a pediatric day-care unit. Pediatrics. 1988;81(1):159-62.

264. Bean $P$, et al. Clinical observations of the impact of maudsley therapy in improving eating disorder symptoms, weight, and depression in adolescents receiving treatment for anorexia nervosa. J Groups Addict Recover. 2010;5(1):70-82

265. Gezelius C, et al. Adolescent patients with eating disorders and their parents: a study of self-image and outcome at an intensive outpatient program. Eat Weight Disord. 2016;21(4):607-16.

266. Rienecke RD, Richmond R, Lebow J. Therapeutic alliance, expressed emotion, and treatment outcome for anorexia nervosa in a family-based partial hospitalization program. Eat Behav. 2016;22:124-8.

267. Rienecke RD, Richmond RL. Three-month follow-up in a family-based partial hospitalization program. Eat Disord. 2018;26(3):278-89.

268. Zanna $V$, et al. Day-hospital multifocal integrated treatment for anorexia nervosa in adolescents: a one-year follow-up. J Child Fam Stud. 2017;26(5) 1460-71.

269. Martin-Wagar CA, Holmes S, Bhatnagar KAC. Predictors of weight restoration in a day-treatment program that supports family-based treatment for adolescents with anorexia nervosa. Eat Disord. 2019. 27(4):400-17

270. Simic $M$, et al. Intensive treatment program (ITP): A case series service evaluation of the effectiveness of day patient treatment for adolescents with a restrictive eating disorder. Int J Eat Disord. 2018;51(11):1261-9.

271. Hoste R. Incorporating family-based therapy principles into a partial hospitalization programme for adolescents with anorexia nervosa: challenges and considerations. J Fam Ther. 2015;37:41-60. 
272. Ornstein RM, Lane-Loney SE, Hollenbeak CS. Clinical outcomes of a novel, family-centered partial hospitalization program for young patients with eating disorders. Eat Weight Disord. 2012;17(3):e170-7.

273. Girz L, et al. Adapting family-based therapy to a day hospital programme for adolescents with eating disorders: preliminary outcomes and trajectories of change. J Fam Ther. 2013;35:102-20.

274. Grewal S, et al. Factors associated with successful completion in an adolescentonly day hospital program for eating disorders. Eat Disord. 2014;22(2):152-62.

275. Henderson $\mathrm{K}$, et al. A family-based eating disorder day treatment program for youth: examining the clinical and statistical significance of short-term treatment outcomes. Eat Disord. 2014;22(1):1-18.

276. Johnston JA, et al. A pilot study of maudsley family therapy with group dialectical behavior therapy skills training in an intensive outpatient program for adolescent eating disorders. J Clin Psychol. 2015;71(6):527-43.

277. Iniesta Sepulveda M, et al. Intensive family exposure-based cognitivebehavioral treatment for adolescents with anorexia nervosa. Psicothema. 2017:29(4):433-9.

278. Ornstein RM, et al. Treatment of avoidant/restrictive food intake disorder in a cohort of young patients in a partial hospitalization program for eating disorders. Int J Eat Disord. 2017;50(9):1067-74

279. Murray SB, et al. Integrating family-based treatment and dialectical behavior therapy for adolescent bulimia nervosa: preliminary outcomes of an open pilot trial. Eat Disord. 2015;23(4):336-44.

280. Green J, et al. Day program for young people with anorexia nervosa. Australas Psychiatry. 2015;23(3):249-53.

281. Seiverling $L$, et al. The effects of a brief behavioral intervention on food refusal in a child with a fear of choking. Clin Case Stud. 2016;15(2):117-25.

282. Williams $K$, et al. Brief, intensive behavioural treatment of food refusal secondary to emetophobia. Clin Case Stud. 2011;10(4):304-11.

283. Fernandez-del-Valle $M$, et al. Muscle function and body composition profile in adolescents with restrictive anorexia nervosa: does resistance training help? Disabil Rehabil. 2016;38(4):346-53.

284. Fisher $\mathrm{M}$, et al. Demographics and outcomes of adolescents with eating disorders treated in residential care. J Adolesc Health. 2015;56(2):S87.

285. Weltzin T, et al. Long-term effects of a multidisciplinary residential treatment model on improvements of symptoms and weight in adolescents with eating disorders. J Groups Addict Recover. 2014;9:71-85.

286. Twohig MP, et al. Effectiveness and clinical response rates of a residential eating disorders facility. Eat Disord. 2016;24(3):224-39.

287. McHugh MD. Readiness for change and short-term outcomes of female adolescents in residential treatment for anorexia nervosa. Int J Eat Disord. 2007;40(7):602-12

288. Pitel AU, et al. Diagnosis and treatment of an adolescent with comorbid type 1 diabetes mellitus and anorexia nervosa. Clin Pediatr (Phila). 1998; 37(8):491-6.

289. Rodrigue J, et al. Multi-modal treatment of an adolescent with anorexia nervosa and insulin-dependent diabetes mellitus: a case report. Fam Syst Med. 1990;8(4):349-58.

290. van der Leer, G., et al., Clinical practice guidelines for the BC eating disorders continuum of services. 2012: www.healthservices.gov.bc.ca.

291. Gowers SG, et al. A randomised controlled multicentre trial of treatments for adolescent anorexia nervosa including assessment of cost-effectiveness and patient acceptability - the TOuCAN trial. Health Technol Assess. 2010; 14(15):1-98

292. Dalle Grave R, et al. Inpatient cognitive behavior therapy for adolescents with anorexia nervosa: immediate and longer-term effects. Front Psychiatry. 2014;5:14.

293. Sibeoni J, et al. Metasynthesis of the Views about Treatment of Anorexia Nervosa in Adolescents: Perspectives of Adolescents, Parents, and Professionals. PLoS One. 2017;12(1):e0169493.

294. Stockford C, et al. Women's recovery from anorexia nervosa: a systematic review and meta-synthesis of qualitative research. Eat Disord. 2019;27(4):343-68.

295. Dukarm CP. Bulimia nervosa and attention deficit hyperactivity disorder: a possible role for stimulant medication. J Women's Health (Larchmt). 2005; 14(4):345-50.

296. Kardas M, et al. Lorazepam in the treatment of posttraumatic feeding disorder. J Child Adolesc Psychopharmacol. 2014;24(5):296-7.

\section{Publisher's Note}

Springer Nature remains neutral with regard to jurisdictional claims in published maps and institutional affiliations.

Ready to submit your research? Choose BMC and benefit from:

- fast, convenient online submission

- thorough peer review by experienced researchers in your field

- rapid publication on acceptance

- support for research data, including large and complex data types

- gold Open Access which fosters wider collaboration and increased citations

- maximum visibility for your research: over $100 \mathrm{M}$ website views per year

At BMC, research is always in progress.

Learn more biomedcentral.com/submissions 